Historic, archived document

Do not assume content reflects current scientific knowledge, policies, or practices. 
? 


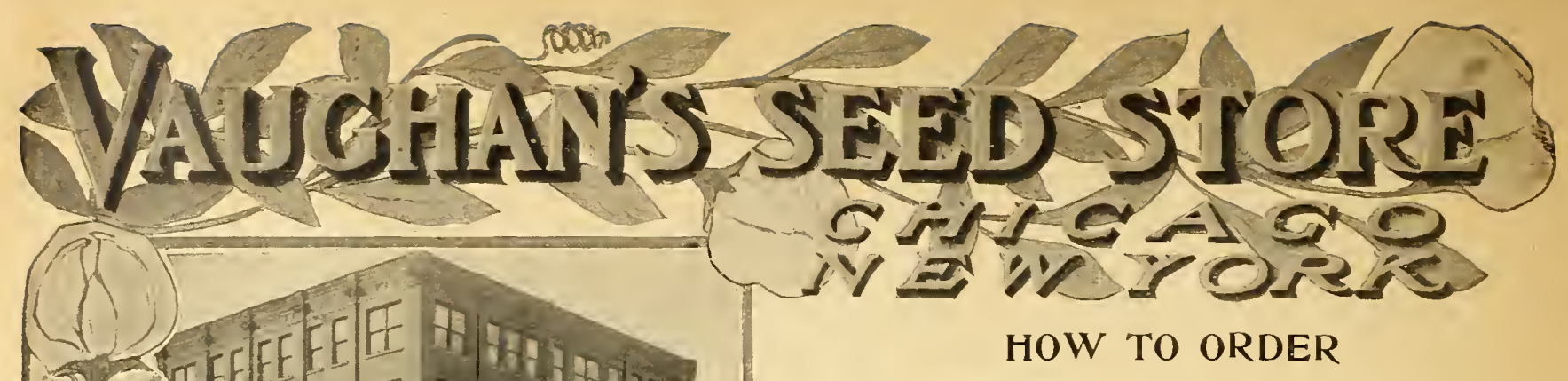

Please read the following carefully:

OUR TERMS ARE STRICTLY CASH WITH ORDER-We do not send C.O. D., as the cost of collecting return charges is quite an unnecessary item of expense, and the prices being given, we can conceive of no necessity to warrant goods being so sent. Prices are not prepaid, escept where specificd.

WE PREPAY by mail in First. Second and Third Zones ONLY on Packets, Ounces and Quarter Pounds (no larger), from Chicago and New York.

For all larger lots, if wanted by mail. ADD POSTAGE AT ZONE RATES. For postal rates, see below.

HOW TO ORDER-We aim to fill your orders immediately. and you can greatly aid us in making them out on your Order Sheet as follows:

1. Place the quantity wanted before each article.

2. Use one line for each kind ordered.

3. As nearly as possible make your list in the same order in which the seeds are catalogued, beginning at the front.

4. Kindly use Special Order Sheet for plant orders, and inquiries and other matters not pertaining to the order should be written on separate sheet. HOW TO SEND MONEY-Send cash with order (as we do not open book accounts for small amounts, and can only send to the value of money received), by New York or Chicago Draft, Registered Letter or Postoffice or Express Money Order; all are cheap and absolutely safe. If local checks are used, 25 cents must beadded to cover the cost of collecting. Make money orders payable to "Vaughan's Seed Store." Include postage if wanted by mail.

ORDERS-Order early. Do not wait until the rush of planting time. We strive to fill all orders promptly and at short notice. but a rush season always and everywhere has its inevitable delays. First come will be first served.

PERISHABLE STOCK-Onion Sets, Sweet Potatoes, etc.. are sold and shipped only at buyer's risk. For damages arising from delay or from heating while in transit we will not be responsible.

\section{OUR RESPONSIBILITY}

It is so manifestly impossible for a seller of any perishable article to be responsible for what may happen to it after it leaves his hands, especially one like seeds. which are planted in the ground under varying conditions of soil and climate, that we, in common with all American seed houses, disclaim respcnsibility as to the crop which may be raised from seeds which we sell.

At the same time in case of any failure to secure proper results caused from some inherent fault in the seeds themselves Vaughan's Seed Store accepts responsibility, not for crop, but to the extent of the amount of money paid for the seeds, if immediately advised. (Or seeds may be returned. See below.)

We wish it understood that all our seeds are sold under the following general non-warranty :

We do not warrant in any way, expressed or implied, the contents or the description, quality, productiveness or any other matter, of any seeds, bulbs, plants, shrubs or trees sold by us. and we will not be in any way responsible for the crop. If the purchaser does not accept these goods on above terms, no sale is made thereof, and he must return them at once, and money will be refunded. Subject to above conditions, we make this sale at the moderate prices at which we sell our goods.

VAUGHAN"S SEED STORE

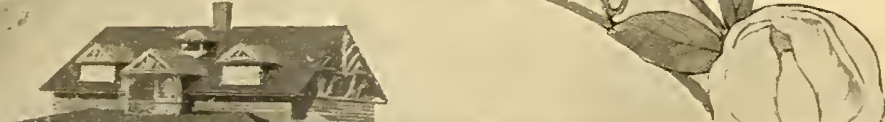

11 the

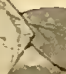

Domestic Parcel Post Rates on Seeds, First Each extrs Plants, Bulbs, Roots, Books, Tools, etc., pound or pound or

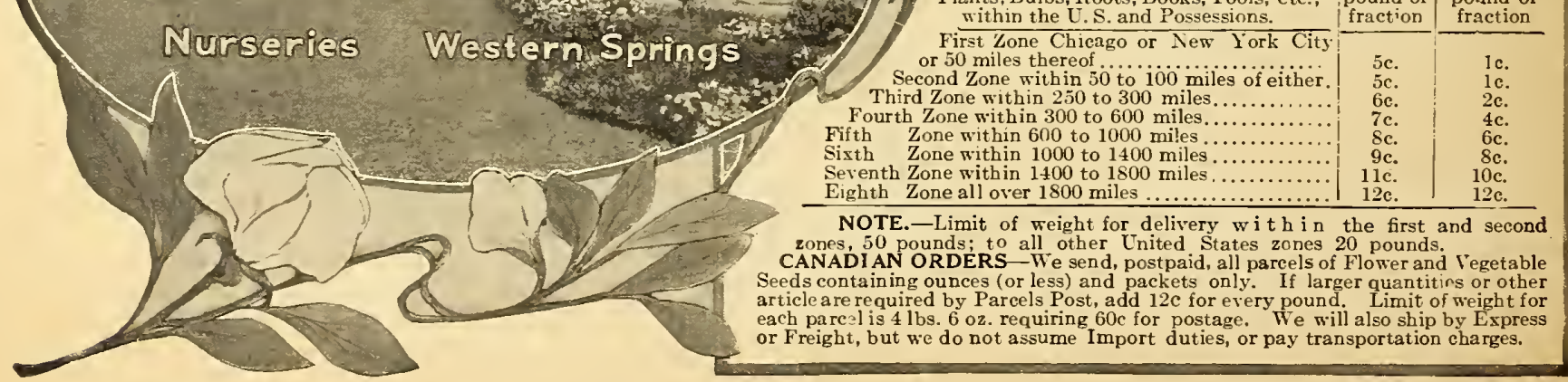


1915 SEED CROPS. In general we may say that vegetable seeds are the shortest for many years. Not only are the European seeds short, but on account of shortage in labor, poor harvest conditions, ignorance of help, they are far behind their usual high standard, both as regards mechanical quality and sclection to type.

We have had a representative in Europe since last June, and we think we are perhaps better fixed for our usual supply of European seeds than any other American firm. One might almost begin at "A" and go through the alphabet raming everything, and say that it was short this season

In America we have had far from a normal season. Wet weather does not producc a good seed harvest. Beans are a practical failure, and many, kinds are almost out of the market, particularly Wardwell's and Davis Wax and Black Valentine, Stringless Green Pod, Longfellow in the green pods. Onion seed, both Globe for big onions and Flat sorts for sets are twice their normal price. Other particularly short items arc Paris Golden SelfBlanching Celery; Carrots (European grown); Sweet Corn, late varieties; Herbs; Peas (dwarf varieties); Large Peppers; Radish (European sorts); Salsify, almost a failure; Spinach very short; Squash and Rutabaga.

We have made our prices low, much lower than the market might demand, for we realize the past year was a hard one for the market, gardener, and we are willing to work on a close margin.

Order early as on many items we may be sold out and then it might be impossible to replace, and if we could it would be impossible to maintain our catalogue prices.

\section{PURE BEAN SEED}

The illustration opposite shows our new Bean and early fie?d Corn warehouse at Ovid, Michigan. Around Ovid we grow on our own farm and by contract, under our direct supervision, a large proportion of the garden Beans we sell. We have been doing very careful work on improving our strains of Beans, and we are pleased that as a result of such work, especially that part of keeping our seed stocks as free as possible from Anthracnose (rust), we were in spite of an almost complete failure of other growers, able to harvest a fair crop. We claim our beans are superior to others in the following points: trueness to type, due to line breeding; vigor, seed selected free as possible from disease. Sample, we put more expense in cleaning than does any other firm.

\section{SURE CROP WAX}

Black seeded-An extra early flat wax bean-absolutely stringless and nearly rust proof. The pods are straight, light golden yellow color, 5 inches in length. A Stringless strain of "Curries Rust Proof." Quart, 50c; 1/2 pk., \$1.90; pk., \$3.75.

\section{LETTUCE WAYAHEAD}

An early Head Lettuce, a superior sort; early as May King, larger in size, darker green and a better market sort. Oz., 10c; $1 / 4$ lb., 25c; lb., $\$ 1.00$.

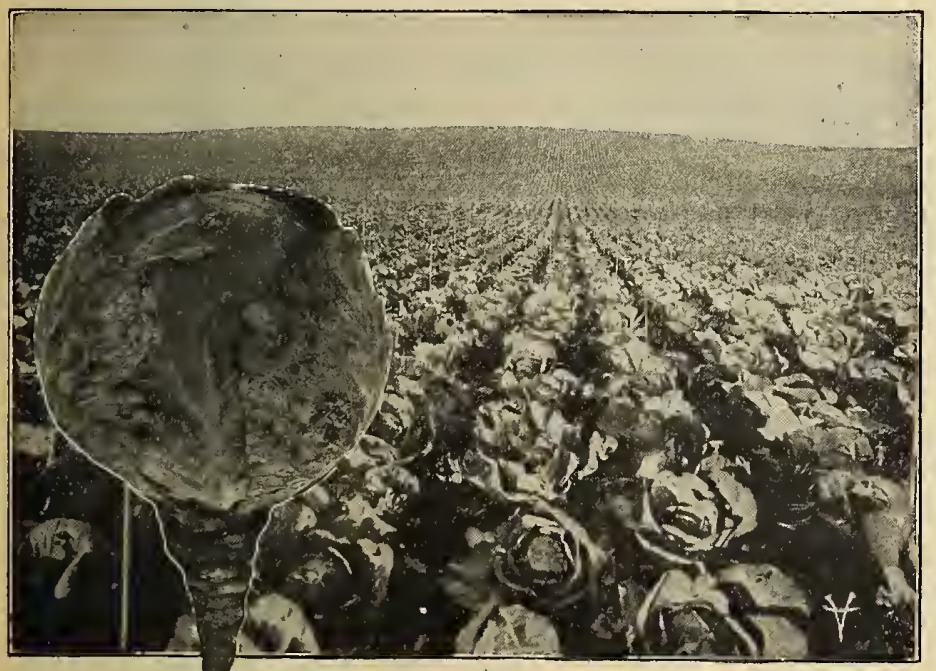

DUTCH WINTER OR HOLLANDER-Growing for Seed Note stakes marking heads for our stock seed

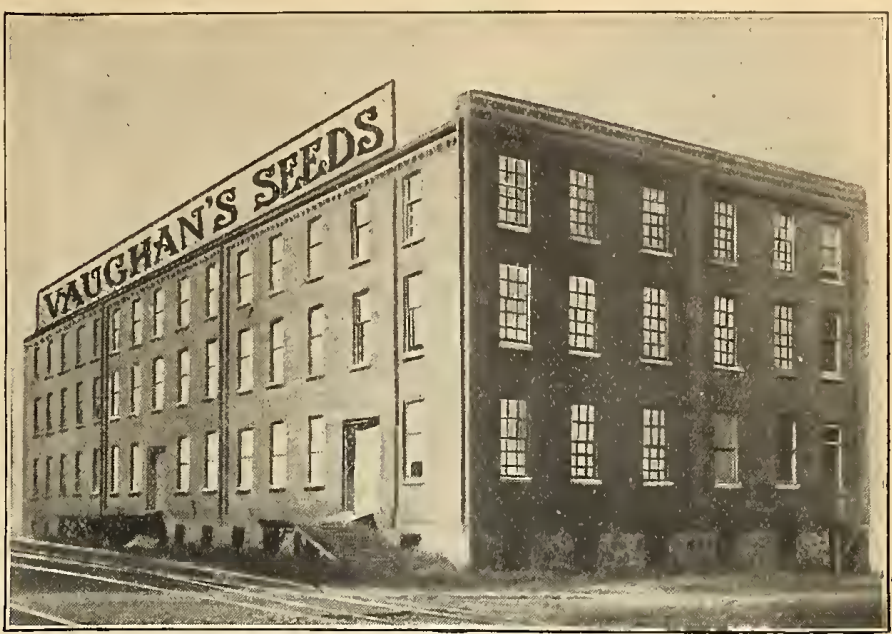

OUR NEW BEAN WAREHOUSE IN MICHIGAN

\section{NEW RED CABBAGE, DANISH STONE HEAD}

A fine, medium late, winter keeping red cabbage, Danish type. Heads round or ball shaped. Very solid; of fine, intense, deep red color. One of the best for market. $1 / 2$ oz., 20c; oz., 35c; 2 oz., 65c; $1 / 4$ lb., $\$ 1.10$; lb., $\$ 4.00$.

\section{COPENHAGEN MARKET CABBAGE}

The earliest cabbage among round or flat headed sorts. It is in season with "Early Jersey Wakefield" and ripens uniformally; heads average 10-pounds, are very compact and firm; has light green dish-shaped leaves, which fold tightly together; short stemmed, grows close to ground, permits close planting.

Originator's seed, Oz., 35c; 2 oz., 60c; $1 / 4$ lb., $\$ 1.15$; lb., $\$ 4.00$.

\section{DUTCH WINTER OR HOLLANDER \\ DANISH GROWN}

Stock Seed. Grown exclusively for Vaughan's Seed Store, by a celebrated Danish Seed Grower, who a few years ago was engaged by us to grow seed for this stock, free from blemish, true and uniform. See illustration. $1 / 2$ oz., 25c; oz., $40 \mathrm{c} ; 2$ oz., $65 \mathrm{c} ; 1 / 4 \mathrm{lb} ., \$ 1.15$; lb., $\$ 4.00$.

\section{CELERY, OR CHINESE CABBAGE}

Pe-Tsai-Improved Chinese Cabbage- has been offered on the vegetable market the past 3 years with considerable success. It should be grown like a late cabbage; planting in July turnip planting time, as early plantings run quickly to seed. The
seed is sown in drills 16 to 20 inches apart and the seedlings thinned two or three times. The full grown plant somewhat resembles a Cos Lettuce in appearance. It has a mild flavor and may be eaten raw or as a salad or cooked. Pkt., 10c, oz., 40c; $1 / 4$ Ib., $\$ 1.25$; lb., $\$ 4.00$

Vaughan's Early Sweet Corns

Grown on our Michigan Farms our extra early high germination true to type Sweet Corns are in a class by themselves for use for gardeners in equal latitudes or further south. For example, our Mammoth White Cory planted around Chicago is at least a week earlier than strains of the same variety offered by other seedsmen.

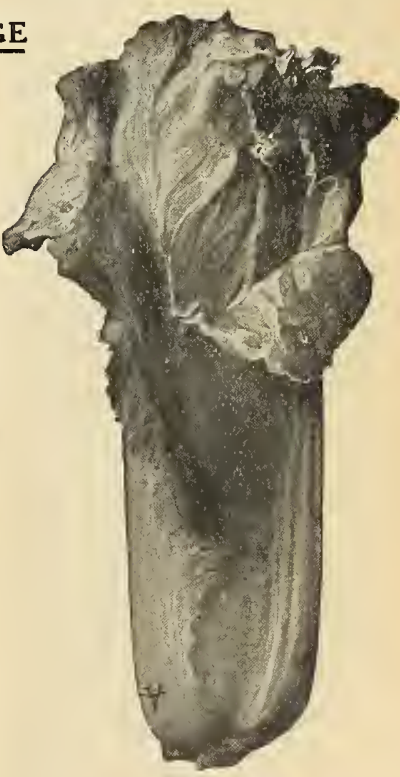

CELERY CABBAGE 


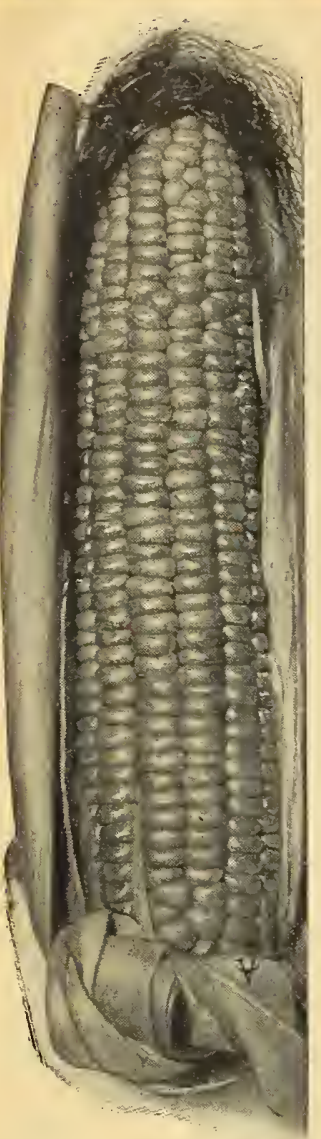

BANTAM EVERGREEN SWEET CORN

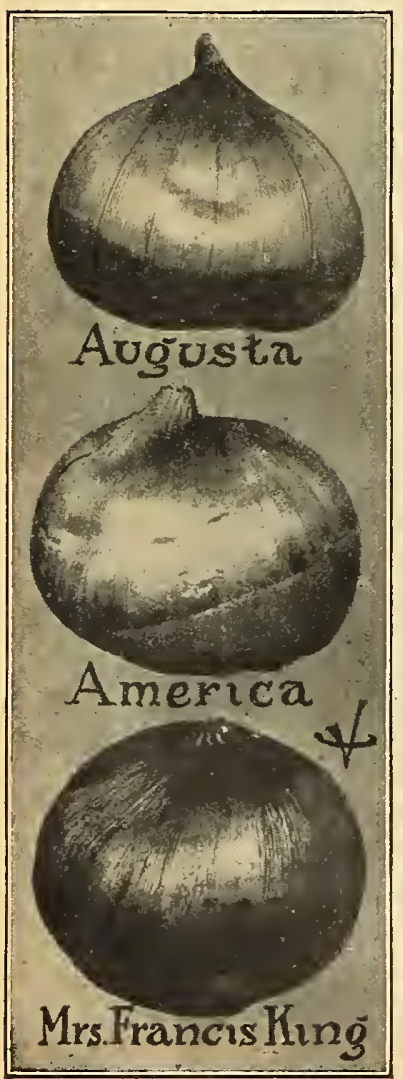

BANTAM EVERGREEN SUGAR CORN

"The sweetest of all Sugar Corns." A cross of "Golden Bantam" and "Stowells Evergreen," the first high quality yellow sweet corn of good marketable size. See illustration. Pt., 20c; qt., 35c; $1 / 2$ pk., $\$ 1.00$; pk., \$1.75; bu., $\$ 6.50$.

\section{LETTUCE TENDERHEART}

Early head lettuce with pale green leaves, outside slightly tinged with reddish-brown. The head is very tightly formed, is slow to run to seed and is very attractive. Oz., 20c; $1 / 4$ lb., 60c; lb., \$1.50.

NEW TOMATO, JOHN BAER

An extra early, very smooth productive Red Tomato of the Bonny Best and Chalks Jewel type. This variety, has created a furor in Tomato sections in the east and is sure to meet with favor wherever a market uses a red Tomato. Pkt., 10c; $1 / 2$ oz., 15c; oz., 25c; $1 / 4$ lb., $80 \mathrm{c} ; \mathrm{lb} ., \$ 3.00$.

\section{NEWEST AND BEST PEAS}

LAXTONIAN. New giant pod early dwarf Pea, almost as early as "Gradus" and yields better, and sells equally as well. This variety may be grown between rows of other crops. This is one of our introductions to the U. S. Qt., 35c; 1/2 pk., \$1.25; pk., \$2.40; bu., $\$ 9.50$.

VAUGHAN'S NEW PEA, TOP O' THE MORN. This ideal early Pea is an improvement on "Little Marvel," which was an improvement on "Nott's Excelsior." This is as early as "Nott's Excelsior," is larger podded, has equal quality and lasts longer. Pkt., 10c; pt., (about 1-lb.), 30c; qt., (about 2-lbs.), 50c; 1/2 pk., $\$ 1.75$; pk., $\$ 3.50$; bu., $\$ 14.00$.

LAXTON'S SUPERB PEA. This is a semi-wrinkled, extra early dwarf pea; permits early planting as it does not rot in the ground, like fully wrinkled peas do. . This takes the place of "Gradus" or "Pilot," the pods being much larger, earlier, and more prolific. Try it, you will find it profitable. Pt., 25c; qt., 50c: $1 / 2$ pk., $\$ 1.50$; pk., $\$ 3.00$; bu., $\$ 12.00$.

\section{Grow Gladiolus for Cut Flowers}

Both in England and the United States shrewd growers of garden vegetables under glass are working rapidly into the cut-flower trade.

In many thickly settled suburbs of eastern cities market gardeners are growing Gladiolus flowers, and young men during the summer and early fall take these flowers in large quantities to summer homes, selling regularly at good prices. The availability of Gladiolus Bulbs for this purpose is marked. The bulbs already contain the young flower staiks, and flower in 8 to 10 weeks from planting. We grow every year on our own farms many thousands of the best selling kinds of these flowers, and are able to offer them much cheaper than they have been previously sold. We illustrate here spikes of these beautiful flowers as well as the bulbs themselves. Every market gardener who reads this should try this spring a few thousands of these bulbs. There is every chance for a good profit in selling some of the same to every one of your customers, whether in private homes or in markets, butcher shops, or stores, in fact, if on your wagon, you will average to sell at more than half the places you call.

\section{THREE BEST COMMERCIAL KINDS \\ VERMILION SCARLET-Mrs. Francis King PINK-America WHITE-Augusta}

First size, $11 / 2$ in. and over, $100, \$ 1.25 ; 1,000, \$ 10.00$. Price of above Second size, $11 / 4$ to $1 \frac{1}{2}$ in., $100,85 \mathrm{c} ; 1,000, \$ 7.00$. Third size (all blooming bulbs) 1 in. and over, 100 , 75 c; $1,000 \$ 6.00$.

These three are the easiest grown and most satisfactory for general use and produce excellent effect when displayed together in vases or planted together in border or in beds on the lawn.

Write for Complete GLADIOLUS LIST. Mailed FREE.

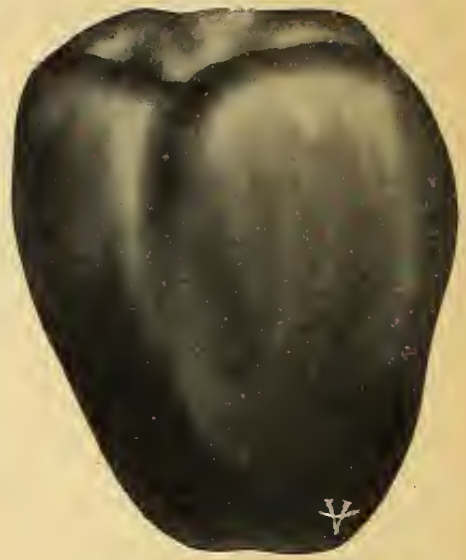

PEPPER, CRIMSON GIANT

\section{TOMATO, EARLY DETROIT}

A real early beauty; meets the requirements of our market g a rdener customers, among Chicago market gardeners it is a great favorite. The fruits are almost globe-shaped, purple in color, firm, ships well. The vines bear through a long season, attractive fruits that find ready sale. $1 / 2$ oz., 12c; oz., 20c; $1 / 4$ lb., 75c; 1 lb., $\$ 2.50$.

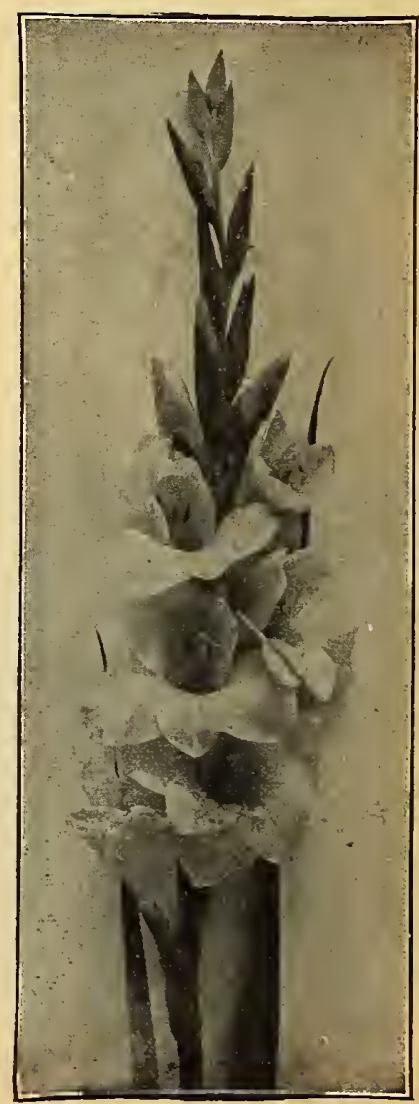




\section{BEANS Bush Wax Variety} season, wonderfully prolific $\operatorname{wax}$ bean, pods

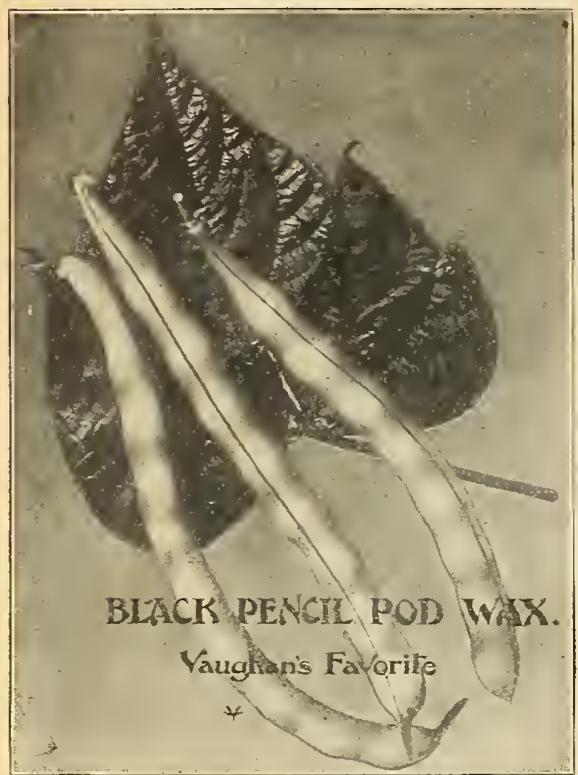

THE PRINCIPAL WAX VARIETIES-Crop Very Short

The principal wax varieties used by market gardeners are: Flat Pods-Davis Kidney IVax, having long straight pods, and white seeds, very prolific, does best on light soil; Wardwell's Kidney Wax, early stringless, pods about $51 / 2$ inches long, very productive, best adapted to a heavy soil; Hodson, a late

DAVIS

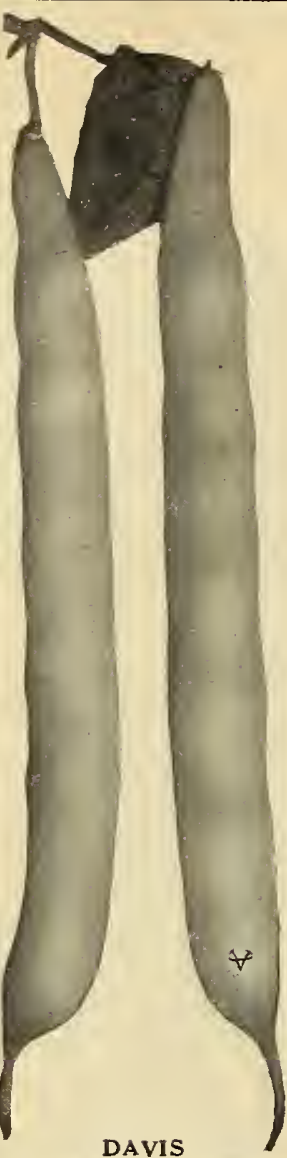
very similar to Davis. Round Pode-Among KIDNEY WHITE WAX the earlies: Round Pod Kidney Wax, Stringless and Prolific Black Tax - for a main crop: Pencil Pod, Currie's Rust Proof, Improved Golden Wax, Valentine Wax, a very early variety in the South; Horticultural Wax, early as Wardwell's, hardier, but not stringless

Currie's Rust Proof.

Challenge Black Wax

Flageolet Wax.

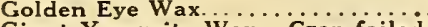

Giant Yosem

$\begin{array}{lll}\mathrm{Qt} . & 1 / 2 \mathrm{Pk} . & \mathrm{Pk} . \\ \$ 0.40 & \$ 1.50 & \$ 3.00\end{array}$

$\begin{array}{lll}.45 & 1.75 & 3.50\end{array}$

$\begin{array}{lll}.50 & 1.75 & 3.50 \\ .45 & 1.75 & 3.50\end{array}$

$1.50 \quad 3.00$

Hodson Wax.......................40 $\quad 1.40 \quad 2.75$

Monster Stringless Wax. Crop failed

Prolific German Black Wax.

Round Pod Kidney Wax.

Stringless Refugee Wax.

Valentine Wax

Wardwell's Kidney Wax.

Sure Crop. (New) ...................
Davis Kidney Wax.

Improved Golden Wax................ $.45 \quad \mathbf{1 . 6 0} \quad \mathbf{3 . 2 5}$

Pencil Pod Wax

Nichigan White Wax. (New)

\section{BEETS}

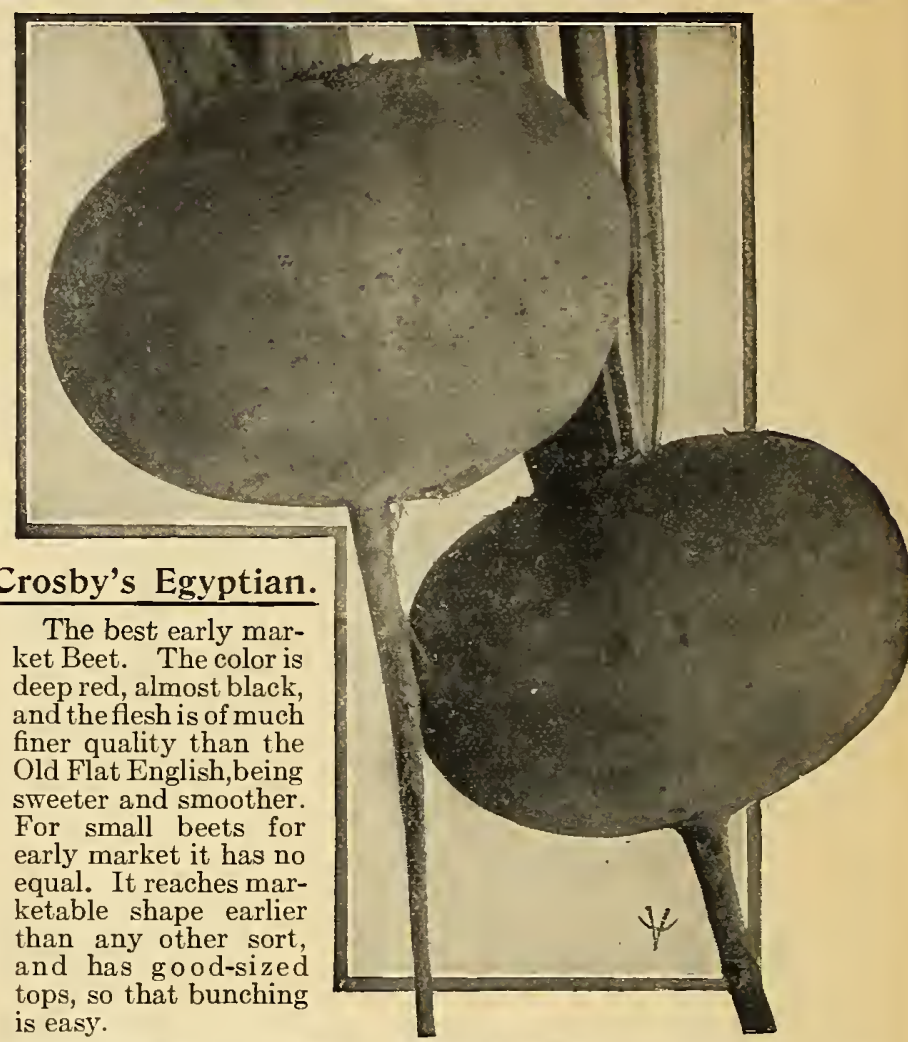

CROSBY'S EGYPTIAN, Vaughan's Selected Stock. Oz., 10c; $1 / 4$ lb., 35c; lb., $\$ 1.00 ; 5$ lb., $\$ 4.50$.

CROSBY'S EGYPTIAN, Regular Stock. Oz., 10c; 1/4 lb., 20c; lb., 65c; 5 lb., $\$ 3.00$.

\section{DETROIT DARK RED TURNIP.}

A grand Beet for bunching for market; tops exceptionally small and upright; roots are perfect turnip shape with small tap roots. Color of skin dark red; flesh bright red; Quality is of the very best, tender and lasting. One of the best for the market gardener and the home garden.

VAUGHAN'S Selected Stock. Oz., 10c; $1 / 4$ lb., 35c; lb., $\$ 1.00$; 5 lbs., $\$ 4.50$.

\section{CRIMSON GLOBE.}

One of the most popular sorts with Market Gardeners for a main crop variety. The roots are medium size; almost globe shape and entirely free from rootlets, leaving the skin entirely smooth. The flesh, blood red, slightly zone, and of highest quality. Price, $1 / 4 \mathrm{lb}$., 25c; lb., 75c; 5 lbs., \$3.50.

Arlington.

Improved Eariy Egyptian

Eclipse Extra Select Stock.

Vaughan's Chicago Market.

Dewing's Early Blood Turnip, Select.

Half Long Blood Red. Very Deep Red.

Hang Smooth Dark Blood.

Pole Beans.

GREEN POD-Burger's Stringless .........30

Dutch Case Knife.

Horticultural Cranberry.

Kentucky Wonder or Old Homestead.

Lazy Wife.

Scarlet Runner.

White Creaseback

WAX POD-Early Golden Cluster Wax.

Kentucky Wonder Wax.

POLE LIMA-Carpinteria...

Dreer's I mproved Lima.

Extra Early Jersey Lima

Early Leviathan Lima.

Ford's Mammo

Ideal Pole Lima ..............

Large Lima, Selected Seed.

Siebert's Early Lima.

Bus.

Edmund's Turnip. Select Stock......................... Fireball............................... 10 MANGEL

Vaughan's Mammoth Long Red............. .15

Champion Yellow Globe

Golden Tankard.

Giant Yellow Intermediate.

Giant Eckendorf

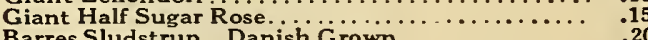

SUGAR BEETS

Vilmorin's Imperial White ................ $\quad .15$

French Red Top. .......

Klein's Wanzleben. Best German..............

BROCCOLI

Purple Cape...

$1 / 4 \mathrm{Ib}$.
.20
.20

Improved Dwarf
1.50

1.50

1.50

1.75

1.50

1.75

1.50

1.75

1.50

2.50

2.50

1.25
1.25 


\section{ONE OF OUR \\ LEADING SPECIALTIES \\ CABBAGE \\ VAUGHAN'S SURE \\ HEADING SEED}

\section{NOTE.}

We supply the most critical market gardeners in the Unitcd States, whose success depends upon buying the hest, with our well known spccial stocks of Cahbage Seed. No greatcr proof of quality, than incroasing husiness with experts.

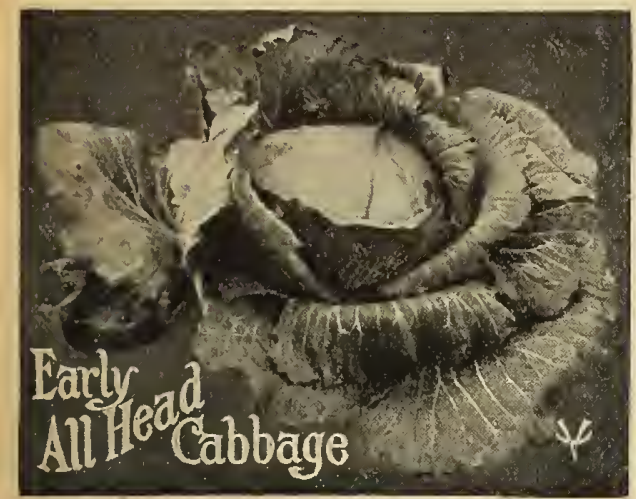

\section{ALL HEAD OR FAULTLESS}

\section{Earliest Large Flat Head}

This Cabbage leads in popularity, and it does so for the reason that it is a sure-to-head sort.

The heads are uniform in shape, large size and of remarkahly good quality Fine for Kraut.

It is a flat head cahhage, has few outer leaves, permitting closer planting to the acre than is possihle with other varieties. It is early, so it combines the necessary variety cabbage. Oz 30c, 2 ozs 55c, $1 / 4$ lb 75c, 1 lb $\$ 2.50$.

\section{DANISH BALL HEAD}

Our strain of this cahhage is grown for us in Denmark hy the most reliable grower there. It is the best late cabbage, for late spring sale and for shipping.

Has long stem, medium size head, extremely solid, long keeper. Oz 30c, 2 ozs $55 \mathrm{c}, 1 / 4 \mathrm{lb} 85 \mathrm{c}, 1 \mathrm{lb} \$ 3.00$.

\section{Early Oblong Varieties}

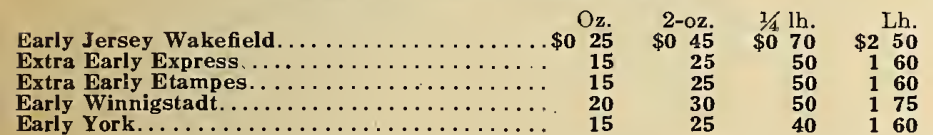

\section{Early Flat and Round Varieties}

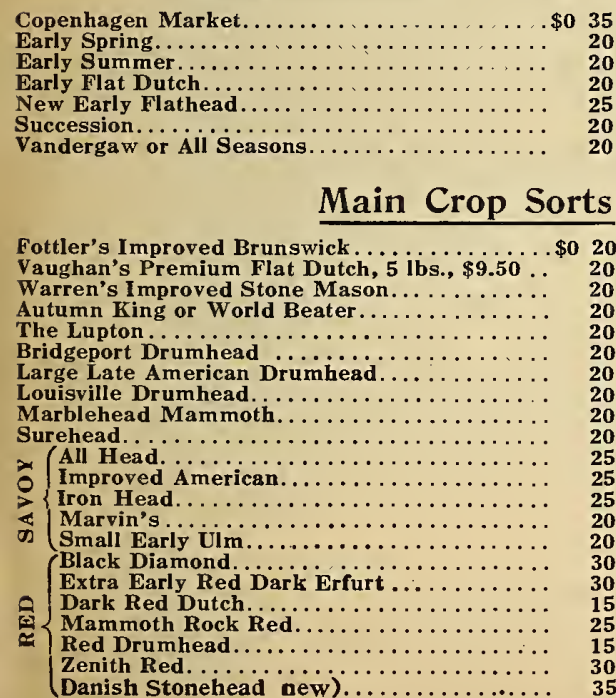

$\begin{array}{llll}\$ 0 & 60 & \$ 1 & 15\end{array}$ $35 \quad 50 \quad 200$ $35 \quad 50 \quad 200$ $45 \quad 70 \quad 250$ $\mathbf{3 5} \quad \mathbf{5 0} \quad \mathbf{2} \mathbf{0 0}$

$\begin{array}{ll}2 & 00 \\ 2 & 00\end{array}$

35

VAUGHAN'S SELECT EARLY JERSEY WAKEFIELD

This is the hest early cahbage in cultivation. It forms fine solid heads of good size and pointed shape, not many outer leaves. Of the extra early conical shaped We varieties, this is the hest in the United States.

We offer an extra fine strain of this seed, grown from selected hard heads. Oz 30c, 2 ozs $55 \mathrm{c}, 1 / 4 \mathrm{lb} 75 \mathrm{c}, 1 \mathrm{lb} \$ 2.50$.

\section{LARGE JERSEY OR CHARLESTON WAKEFIELD}

This sort is larger heading, than the Early Jersey Wakefield. It matures a few days later, with larger heads; hrings higher prices in the market.

It is popular with Southern planters. Re-selected seed. Oz 25c, 2 ozs 45c, $1 / 4$ lb 70c, 1 lb $\$ 2.50$.

\section{DUTCH WINTER OR HOLLANDER HOLLAND GROWN}

This cabbage is most universally grown throughout the Wisconsin, Michigan, Illinois and Indiana Cabbage growing districts.

The heads are very solid, hut not large, they are the right size and shape to meet the demands of the consuming puhlic. Short stem
Our strain of this cannot be surpassed: it has produced most successful results Our strain of this cannot be surpassed; it has produced
in every district. Oz $30 \mathrm{c}, 2$ ozs $55 \mathrm{c}, 1 / 4 \mathrm{lb} 85 \mathrm{c}, 1 \mathrm{lb} \$ 3.00$.

\section{DUTCH WINTER OR HOLLANDER 酐 DANISH GROWN}

Vaughan's Private Stock Seed, a strain grown for us from selected seed . Vaughan's Seed Store. Oz 40c, 2 Ozs 65c, 1/4 lb. $\$ 1.15,1$ lb. $\$ 4.00$.

\section{DWARF AMAGER OR SHORT STEMMED DANISH BALL HEAD}

A variety very similar to the Dutch Winter or Hollander. We import the $\$ 3.00$.

\section{VAUGHAN'S BRIDGEPORT DRUMHEAD}

The best largc, fall shipping cabbage in existence. Our strain of this cabhage, of which we are the introducers, has been selected by us for twenty years, and the original type has not only heen kept up but improved. A field of them is more uniform than any other sort.

Fine for slicing, for Kraut. for general table use it is unsurpassed. Oz 20c, 2 ozs $35 c, 1 / 4$ lb 50c, 1 lb $\$ 2.00$.

Glory of Enkhousen. A round-headed, very solid, fine rihhed, best hardest heading, long keeping quality early cabhage. We think this about the hardest heading, long keeping, early sort. It might he called a late strain of Second
Earlies. Live gardeners should give it a trial. Oz. 25c, 2 ozs. 45c, $1 / 4$ 1b. 70c, 1 lb. $\$ 2.50$.

Danish Summer Ball Head. This is the Danish Ball Head of early Winter Ball Head, except that it is smaller and may be brought in with the very early flat head sorts. There is a trace of curlinesf in its outer leaves and a delicate very enthusiastic. $1 \mathrm{oz} .25 \mathrm{c}, 2 \mathrm{ozs} .40 \mathrm{c}, 1 / 4 \mathrm{lb}$. $70 \mathrm{c}, 1 \mathrm{lb}$. $\$ 2.50$.

For full descriptions see our large illuslrated descriptive catalog. 


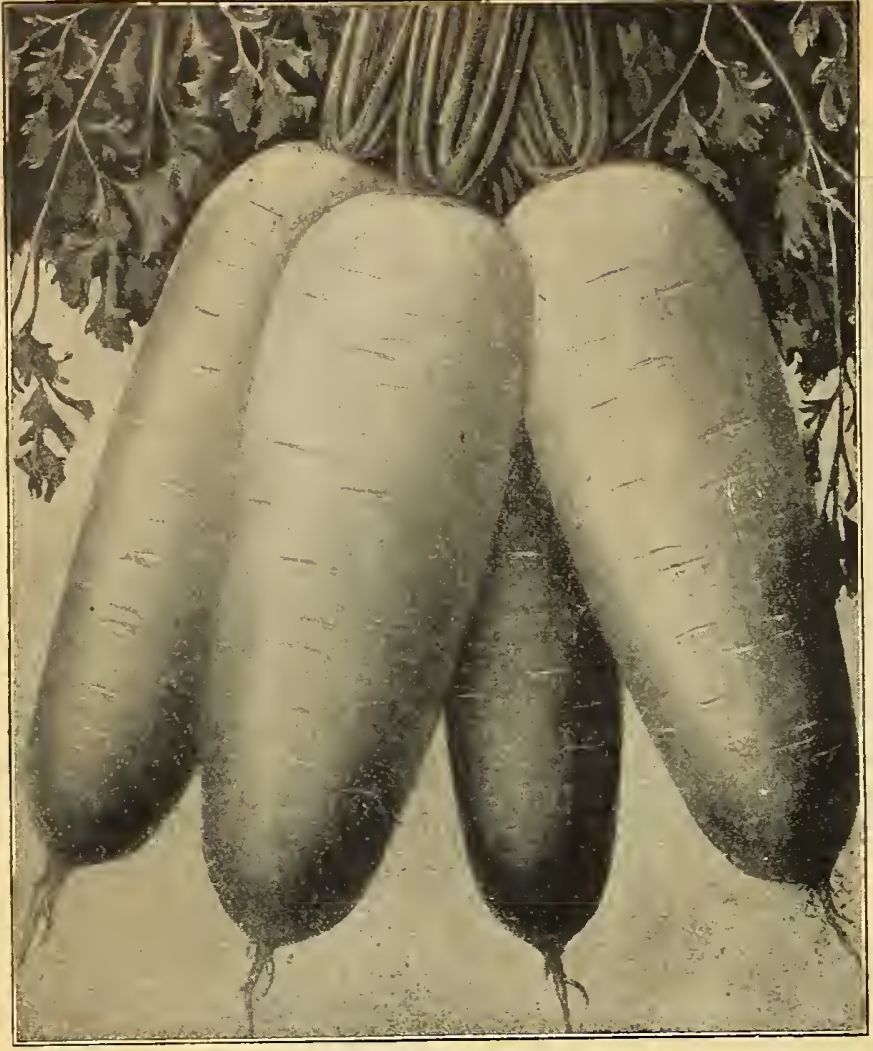

EARLY CHANTENAY

\section{A R $A$ For early bunching, gardeners will find Chantenay unsurpassed. For general crops, our Select Danvers;
for feeding, Mastodon and Belgians. \\ FOUR LBS. TO THE ACRE}

Our Carrot Seed is raised by the most careful and experienced growers, who know the importance of selection. The Early Scarlet Forcing is the earliest, followed by Early Short Scarlet, about three inches long; Oxheart, Nantes, and Chantenay follow, these being from four to six inches. Select Danvers is a little longer, and Long Orange the longest of all.

There is an immense superiority in our stocks over the cheaper California grown seed, and it will satisfy the most critical market gardener.

\section{CHANTENAY.}

The best for early bunching purposes.

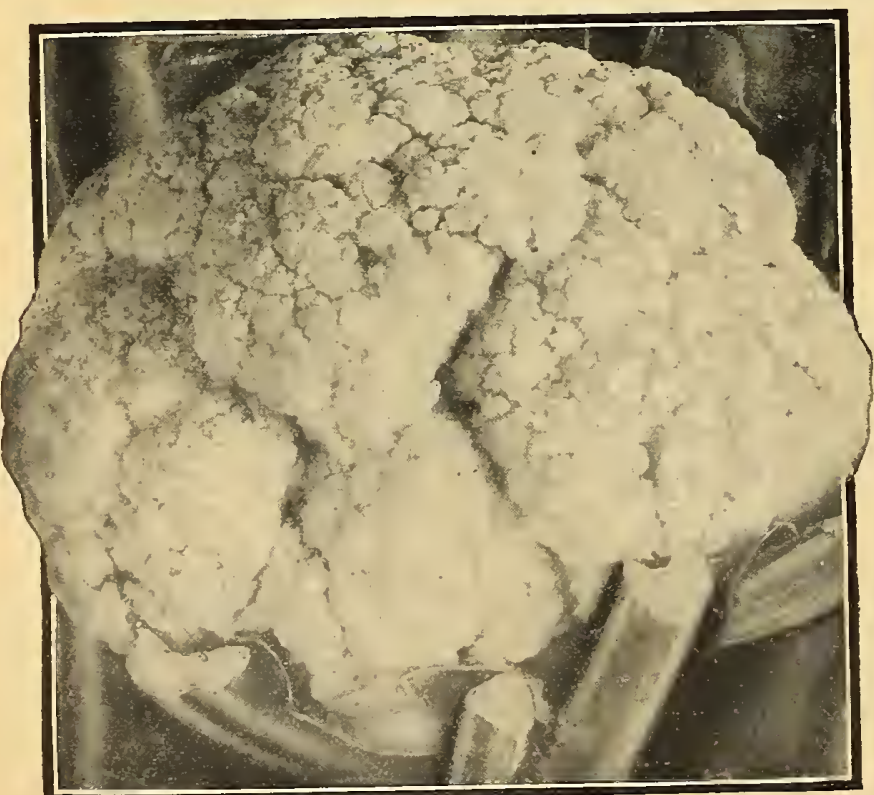

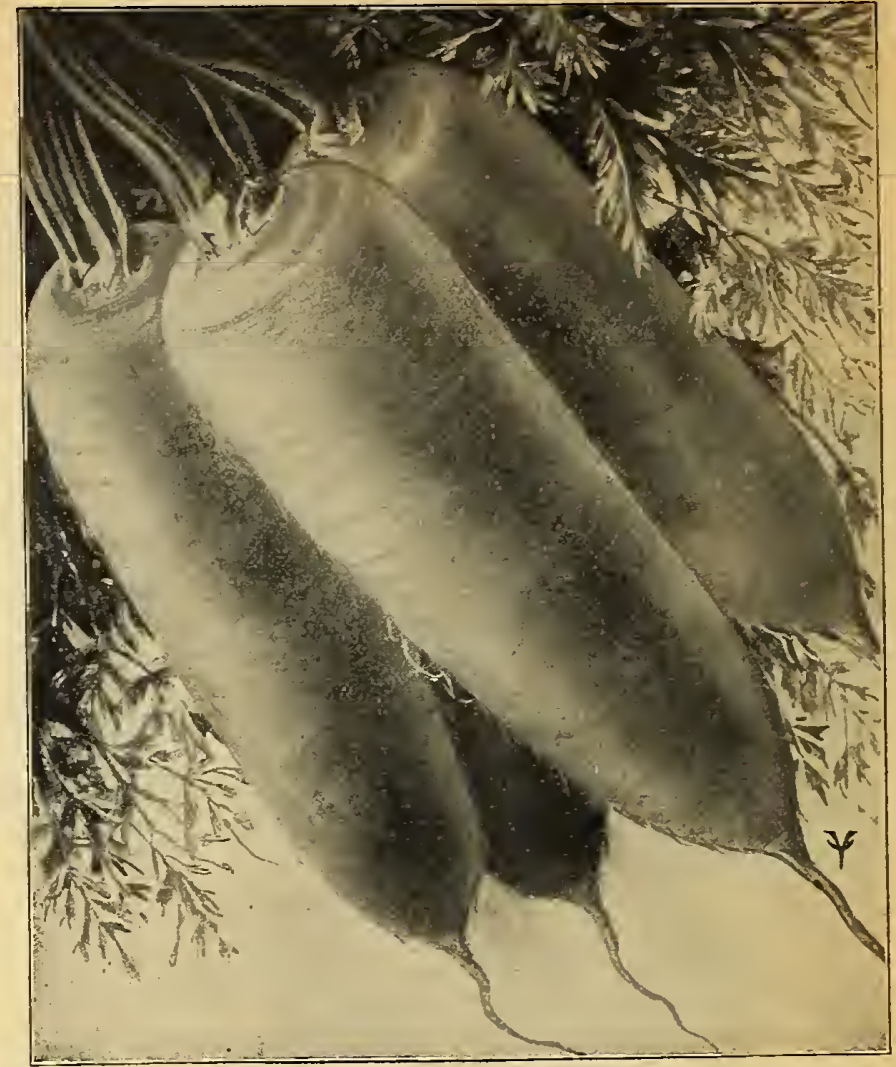

VAUGHAN'S SELECT DANVERS

VAUGHAN'S SELECT DANVERS TheGardener'sfavorbeen one of our special strains of seed during our 38 years in business. As a Carrot to fill a Carket marketable for the greatest yorgest roots orange color, 6 to 7 inches long with a blunt point.

VAUGHAN'S SELECT DANVERS.

Best gtrain of this sort. Uniform. Good color

Oz. $1 / 4 \mathrm{Lb}$. Lb. $5 \mathrm{Lbs}$.

and a splendid yielder.................\$0.15 $\$ 0.40 \quad \$ 1.25 \quad \$ 6.00$ Ins. Long.
2. Very Early Scarlet (French Horn) ........ .20
$\begin{array}{lll}.45 & 1.50 & 7.00\end{array}$
4. Early Short Stump Rooted (Dutch Horn).. .20
5. Guerande or Oxheart................ .15
6. Nantes Half Long Scarlet, stump rooted.. .15
8. Danver's Half Long, regular stock....... .15
14. Improved Long Orange............. . 10
10. White Intermediate or Mastodon....... .10
16. Long White Belgian, green top......... . 10
16. Long Orange Belgian ............... .10

$\begin{array}{lrl}.45 & 1.50 & \mathbf{7 . 0 0} \\ .45 & 1.50 & \mathbf{7 . 0 0} \\ .35 & \mathbf{1 . 1 0} & \mathbf{5 . 0 0} \\ .35 & \mathbf{1 . 1 0} & \mathbf{5 . 0 0} \\ .35 & \mathbf{1 . 1 0} & \mathbf{5 . 0 0} \\ .30 & .90 & 4.25 \\ .20 & .65 & \mathbf{2 . 7 5} \\ .20 & .60 & \mathbf{2 . 7 5} \\ .20 & .60 & \mathbf{2 . 7 5}\end{array}$

\section{CAULIFLOWER of the seeds in buying, in} which price should never be questioned.

Vaughan's Earliest Dwarf Erfurt Combines a 11 pedigree Vkt., 25c.; $1 / 4$ oz., 50c.; oz., \$1.75; 1/4 lb., \$7.00; lb., \$26.00.

Dry Weather For dry climates and dry seasons. Very sure heading and Pkt., 20c; 1/4 oz., 60c; oz., \$2.00.

Danish Snowball This is a grand second early. It is the resuit of long, Danish Snowball careful selection, and uniformly produces even regular heads. Through many seasons it has proven itself reliabl

Oz. $1 / 4 \mathrm{Lb}$. Lb.

\$0.40 $\$ 1.50$

Extra Early Paris.....................................40 1.50

Algiers, large late $\ldots \ldots \ldots \ldots \ldots \ldots \ldots \ldots \ldots \ldots, \quad .45 \quad 1.75$

Algiers, large late...............................5. $\quad \mathbf{5 0} \quad \mathbf{2 . 0 0}$

Lenormand's Short Stem Manmotive................. 1.00

Extra Early or Second Erfurt, Pkt., 10c; $1 / 4$ oz., 35c... $1.25 \quad 4.50$

Large Early Erfurt, $1 / 4$ oz., 30c.................. $\quad .75 \quad 2.50$ 


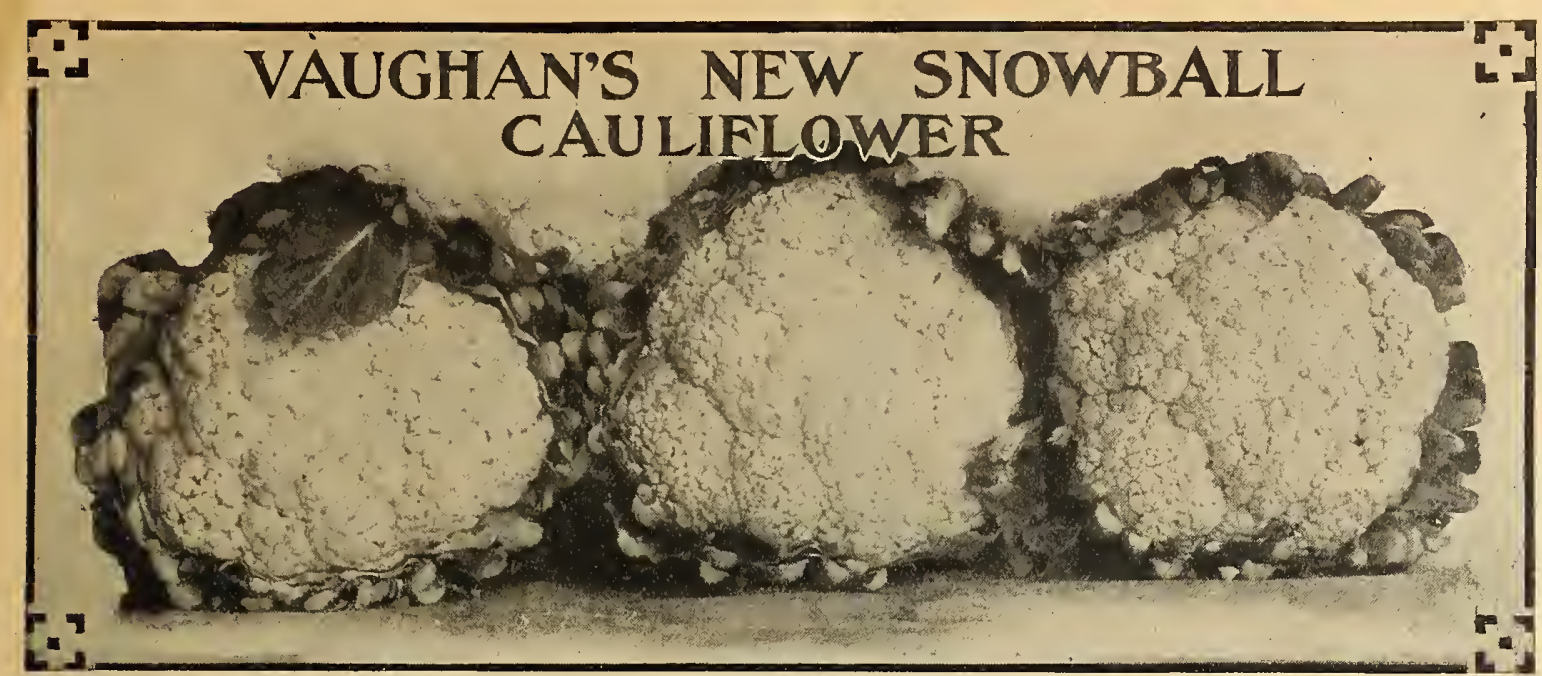

Vaughan's
New Snowball
Cauliflower
The best general
purpose variety either
for Spring or Fall
planting.

Vaughan's New Snowball Cauliflower is a specialty of our house. It is on such particular seed as Cauliflower, in which the least variance from the true strain results in great injury to the grower, that a seed house builds up its reputation. We know our Cauliflower is the equal of anything that can be produced. In our trial ground tests we have tried nearly every strain of cauliflower offered on the market and, while we have found does any large seed house in the United States just so that we can have it as near perfection as it is possible for man to grow it. High bred Cabbage and Cauliflower does not germinate as well as less carefully bred strains. Nevertheless we have taken such pains to reclean and re-sift our seeds after receiving them from the grower that our seed is always up to standard of growth. Head usually 9 to 10 inches across, perfectly white and very solid, deep and compact.

Vaughan's New Snowball. Pkt., 25c; $1 / 4$ oz., 65c; $1 / 2$ oz., $\$ 1.25$; oz., $\$ 2.00 ; 1 / 416 ., \$ 8.00$; lb., $\$ 32.00$. Vaughan's New Snowball Cauliflower is put up in special packages, sealed with our TRADE MARK with distinctive paper and and printing, as follows: PACKETS, QUARTER OUNCES, HALF OUNCES. ONE OUNCES.
THE seed of this with the greatest care only from perfectly developed heads, which yield but little seed. Good Cauliflower seed is always high in price; cheap Cauliflower is a poor investment, because it cannot be good.

The best seed of this type of Cauliflower comes from Amager Island, near Copenhagen, Denmark. There the winters are mild, causing little loss from rot in the seed heads, and the cool, moist summers give ideal growing conditions for this vegetable.

Available ground is scarce and values high, so intensive culture is necessary.

Vaughan's Snowball is the result of years of careful selection by an experienced and most painstaking gardener, under these conditions.

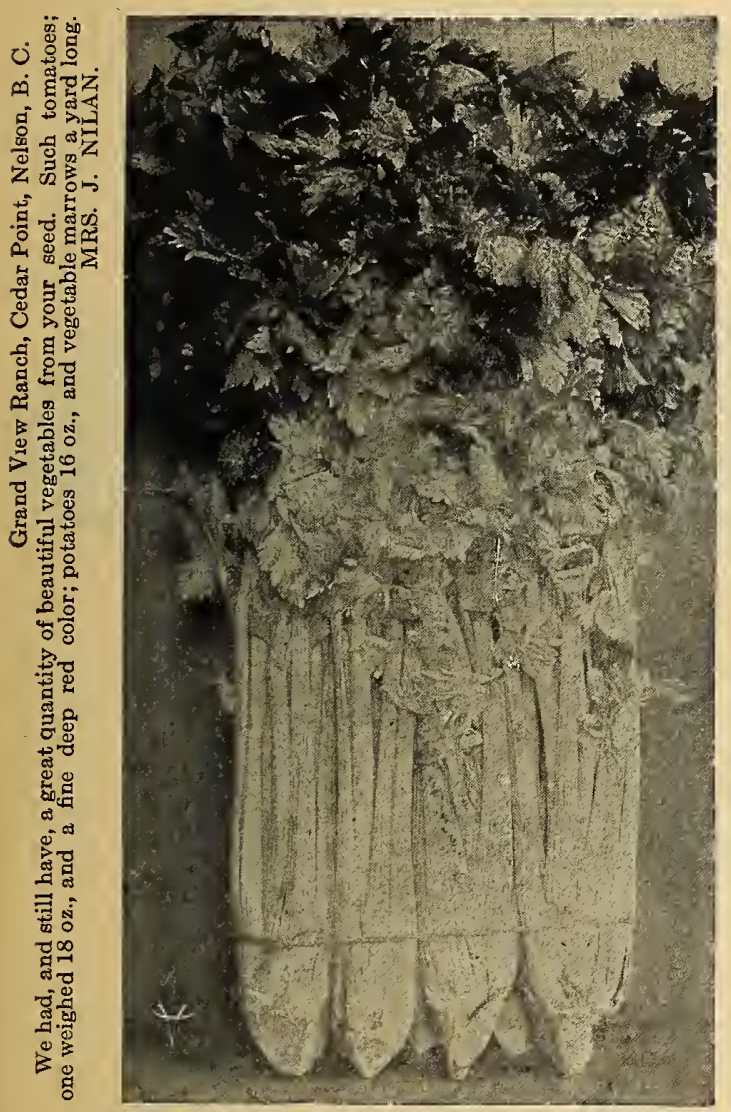

WHITE PLUME, Vaughan's Selected Stock.

VAUGHAN'S CELERY MANUAL

Written by a practical grower of 20 years* experience. Revised and published by J. C. Vaughan. Price, postpaid, 50c. Will be sent free if requested with a Celery seed order of $\$ 3.00$ or with any general order for other seeds amounting to $\$ 5.00$.

\section{White Plume, Self-Blanching-Vaughan's Selected Stock}

We have not yet found a Celery that is as early and of as good a flavor, as crisp and tender as our selection of this sort. We sell large quantities of this seed to market gardeners, who find it uniformly white and free from green or hollow stalks. It is not a good keeper, but it is excellent for Fall and early winter use. $1 / 2$ oz., 12c; oz., 20c; 2 oz., 30c; $1 / 41$ lb., 50c; lb., $\$ 2.00$. WHITE PLUME.-Regular Stock. 1/2 oz., 10c; oz., 15c; 2 oz., 25c; $1 / 4$ lb., 40c; lb., $\$ 1.50$. Golden Self-Blanching-Vaughan's Selected Stock This is the early use. The stalks are much broader and heavier than those of the White Plume, and greatly superior in quality. It is ready for use nearly as early, producing dwarfer and much larger bunches of broad, heavy stalks, blanching to a deep golden yellow. The handsome color, crispness tenderness, freedom from stringiness, and nutty flavor of this variety make it only necessary to be tried in order to establish it as the standard of excellence as an early sort. $1 / 20 z$., $65 \mathrm{c} ;$ oz.,
$\$ 1.25 ; 2$ oz., $\$ 2.25 ; 1 / 4$ lb., $\$ 4.00$.

GOLDEN SELF-BLANCHING-Regular Stock. $1 / 2$ oz., 25c; oz., 45c; $1 / 4 \mathrm{lb} ., \$ 1.50 ; \mathrm{lb} ., \$ 6.00$. "Winter Queen" This is without doubt the most valuable variety of Celery for Winter Wint Spring use. It is also much stouter, thicker and heavier, with double the amount of heart of any known Celery. The plant is of close habit and blanches to a beautiful cream white. Ribs perfectly solid, crisp and of a delicious nutty flavor. Grow Winter Queen once and you will always grow it. $1 / 2$ oz., $12 c$; oz., 20c; $1 / 4$ lb., 50c; lb., $\$ 2.00$.

Vaughan's Giant Golden Heart The best Celery for Winter Storage. Ever public favor and rightly so, for it is not only the best keeper, but it is large, solid, as sweet as a walnut and of a beautiful golden color. It is a selection from the Dwarf Golden Heart; grows much larger than its parent. Oz., 15c; $1 / 4$ lb., 40c; lb., $\$ 1.50$.

\section{STANDARD CELERIES}

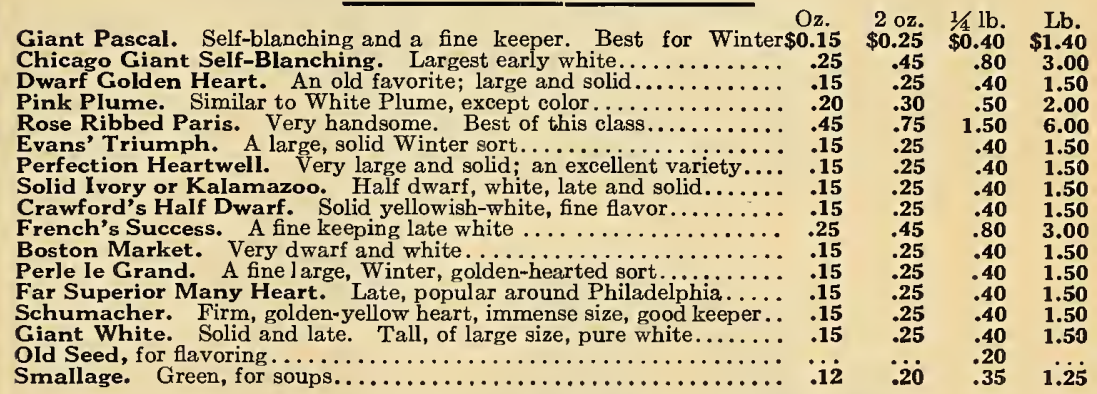

\section{CELERIAC, TURNIP ROOTED CELERY}

Delicatess. Produces perfectly smooth, oval roots with very few side roots. A delicious Produces perfectly smooth, oval roots with very few side roots. A delicious
flavor, much superior to other sorts. Pkt., 10c; 2 for 15c; oz., 40c; $1 / 4 \mathrm{lb}$., Large Erfurt. A standard large growing variety. Oz., 35c; $1 / 4 \mathrm{lb}$ lb, $\$ 1.00$.

Earliest of All. Very early, ready in June. Pkt., 10c.

Giant Prague. (Prager Reisen Sellerie.) The largest of all Celeries. Flavor excellent. 


\section{SWEET CORN vauhar's SWEET CORN Estra salected}

\section{THE FOUR BEST GARDEN VARIETIES}

Mammoth White Cory. One of the largest and best extra early large fine shaped ears ready days before other large sorts. The ears are 12 rowed, very symmetrical and handsome, with no opening between the rows at the base. The grain is large, broad, very white and of remarkably good quality for such an early sort. The size and beauty of this variety gives it ready sale large. $1 / 2$ Pk 55c, pk $\$ 1.00$, bu $\$ 4.00$.

Improved Early Champion. The Earliest Large Sweet Corn days. The new variety is without question the earliest large sweet Corn yet the first early small sorts. Ears nearly as large as the Mammoth; 12 rowed; pure white kernels, with medium ears to the stalk. The best kind for early and late planting. $1 / 2$ Pk 55c, pk. $\$ 1.00$, bu $\$ 4.00$.

Stowell's Evergreen. The most popular main crop Sweet Corn. of fine flavor A late our effort for many years. Seed grown near the Eastern Atlantic Coast has always shown by its flavor and shriveled, ripened kernels the highest percentage of sugar known. We offer both selected seed from Eastern grown stock and pk 55c, pk $\$ 1.00$, bu $\$ 4.00$. Western grown, qt 25c, $1 / 2 \mathrm{pk} 50 \mathrm{c}$, pk $95 \mathrm{c}$, bu $\$ 3.75$.

Country Gentleman. One of the sweetest of all Sweet Corn, and stalks averaging three ears, sometimes as many as five; kernels and cobs are pure white, cob small, kernels deep, ears average nine inches in length. Qt 25c, $1 / 2$ pk $60 \mathrm{c}$, pk $\$ 1.15$, bu $\$ 4.50$.

\section{EXTRA EARLY VARIETIES.}

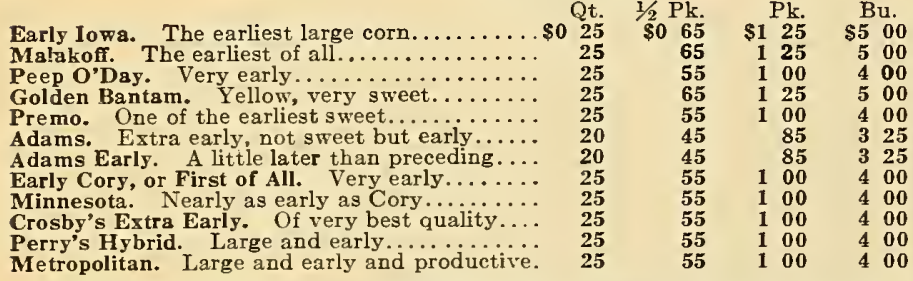

\section{CUCUMBER S}

Improved Long Green. Sclection from Long Green. Vines rigorous and productive, nearly as large as the Shorter Sort; fruit about 12 inches long, firm and crisp. Young fruits make exce.

Cool and Crisp. Skin dark green, almost black, covered with knobs, on which the spines set, giving the pickles a very attractive appearance. Very early and prolific, as a cucumber it is splendid. Oz 10c, $1 / 4$ lb 25c, lb 80 c.

\section{PICKLING VARIETIES}

Westerfield's Chicago Pickle. One of our specialties. The leading pickling concerns in the country buy our selected seed, it is the best. Oz 10c, $1 / 4 \mathbf{l b} 25 \mathrm{c}$, Ib $80 \mathrm{c}$. Snow Fancy Pickling.
Oz $10 \mathrm{c}$, 1 . 1 lb $30 \mathrm{c}, \mathrm{lb} 90 \mathrm{c}$.

Vaughan's XXX Pickling. A fine pickle sort, easy to pick, the fruits proruding from beneatt the foliage. Oz $10 \mathrm{c}, 1 / 4$ Ib $25 \mathrm{c}$, 1b 80c.

Jersey Pickling. A popuiar pickle. Oz 10c, $1 / 1 / 1 b \quad 25 \mathrm{c}, 1 \mathrm{~b} 75 \mathrm{c}$.

Jersey Pickling. A popuiar pickle. Oz 10c, $1 / 4$ lb 25c, Ib 75c.

Cumberland Pickle. A White spine. Oz $10 \mathrm{c}, 1 / 4 \mathrm{c} 25 \mathrm{c}, 1 \mathrm{~b} 75 \mathrm{c}$. $75 \mathrm{c}$

Fordhook Pickle. Medium size, very prolific. Oz $15 c, 1 / 41 b 25 c, 1 b 75 c$.

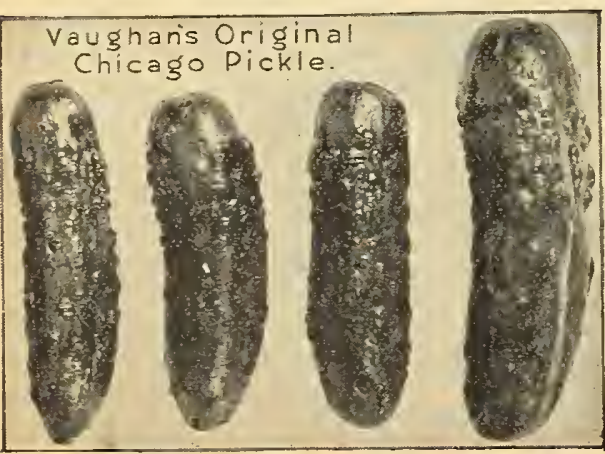
Green Prolific or Bos-

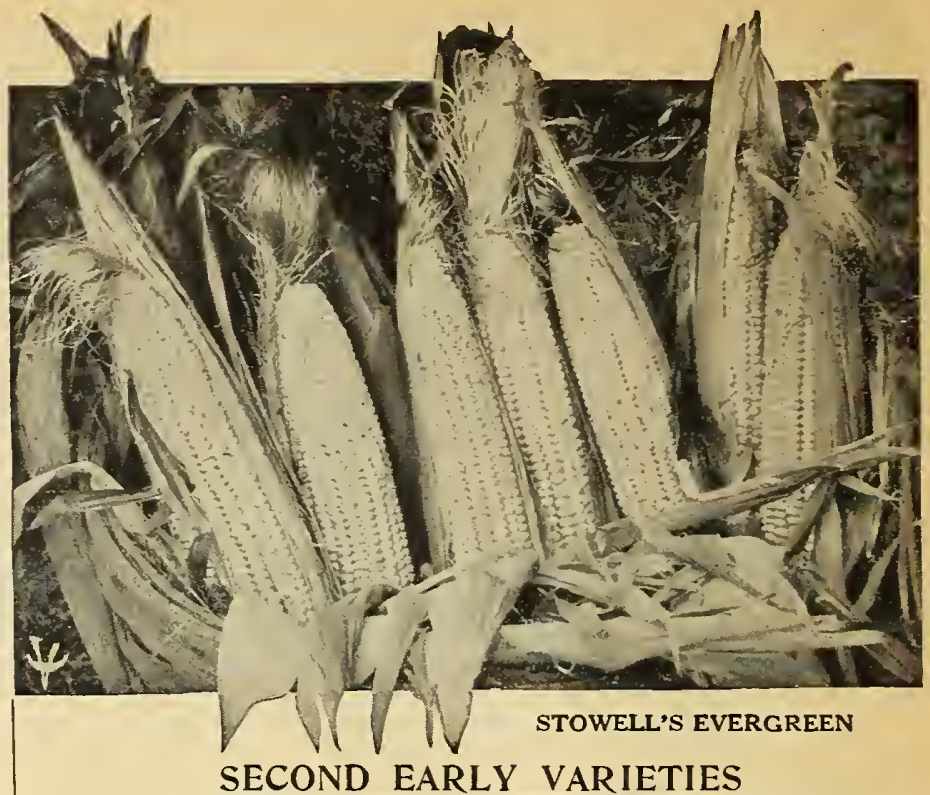

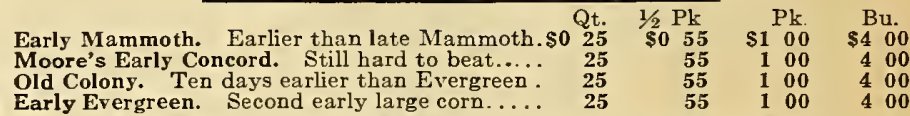

\section{LATE OR GENERAL CROP VARIETIES}

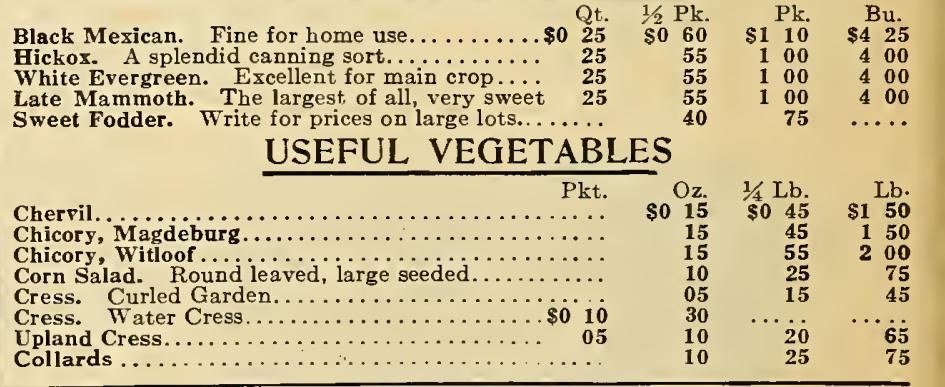

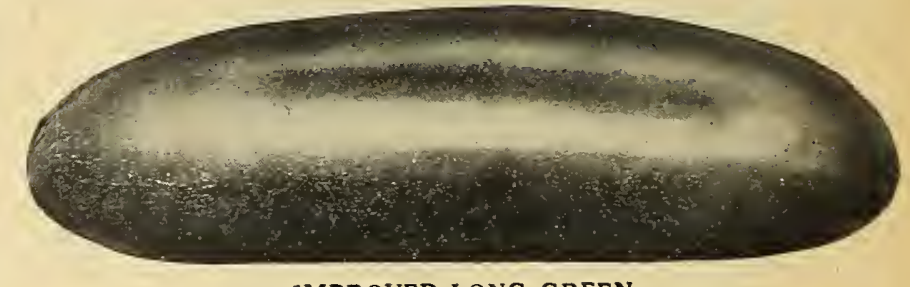

IMPROVED LONG GREEN

\section{WHITE SPINE STRAINS}

Evergreen, or Extra Long White Spine. One of the best table sorts, splendid for forcing under glass. A strain producing fruits frequently 12 in. long, smooth, round, handsomely colore

Daris Perfect. The finest type of extra long white spine. Our seed is raised under our direct supervision. Oz $10 \mathrm{c}, 1 / 4 \mathrm{lb} 30 \mathrm{c}, \mathrm{lb} 90 \mathrm{c}$.

Vaughan's Famous Arlington. The best of all medium length White Spine Cucumbers. Oz 15c, $1 / 4$ lb 30c, lb $\$ 1.00$.

Improved White Spine. Medium length, vines vigorous, very productive, ven shaped fruits, light green. Oz $10 \mathrm{c}, 1 / 4 \mathbf{1 b} 25 \mathrm{c}$, Ib $75 \mathrm{c}$.

Early Cyclone. Early, short, of dark green color which it holds well. The arliest of all Cucumbers. Oz 10c, $1 / 4$ lb 25c, lb 80c.

$1 / 4$ lb $25 \mathrm{c}, 1 \mathrm{~b} 75 \mathrm{c}$.
West India Gherkin. Very small with many spines. Oz 10c, $1 / 4$ lb $40 \mathrm{c}$, b $\$ 1.35$.

Early Frame. Short green sort. Oz 10c, $1 / 4$ OTHER SORTS

Emerald. Smooth dark green. Oz 10c, $1 / 41 b 25 c$, b $80 c$.

Early Cluster. Small fruit, borne in clusters. Japanese Climbing. Small fruits, very prolb $\$ 1.00$.

Boston Forcing White Spine (Vaughan's). Darker than Arlington. More (to 11 in. $\mathrm{Oz} 15 \mathrm{c}$ lb $30 \mathrm{c}$, lb $\$ 1.00$.

Fordhook Famous. Extra long, good dark green color. One of the best for market gardeners. Oz $15 \mathrm{c}, 1 / 4 \mathrm{lb} 30 \mathrm{c}, \mathbf{l b} 90 \mathrm{c}$.

Rockyford. Selcetion of Extra Long White Spine. Very prolific. Retains olor well; a shy seeder. Oz 10c, $1 / 4$ lb 25 c, lb 80 c.

New Century. A long, thick strain of White Spine. Oz. 10c, 1/y Ib 25c, 1b 75c.

\section{ENGLISH FRAME CUCUMBERS}

Rollison's Telegraph. Pkt 50c, 1/8 oz \$1.00, 1/4 Oz \$1.75.

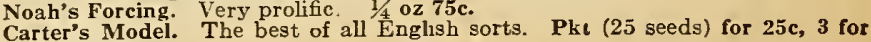
Carter's Model. The best.
(1) 1.00 . 
UANDELION. Thick Leaved or Cabbaging. Crop very short. Pkt., 10c; oz., 40c.

GARLIC. Selected Bavarian. Originally came from settlement of Illinois for a number of years. It is larger and more even than ordinary garlic, keeps much longer 3 lbs., $\$ 1.00 ; 5$ lbs., $\$ 1.50$; 10 lbs., $\$ 2.90 ; 100$ lbs., $\$ 28.00$ Ordinary Garlic. Write for prices.

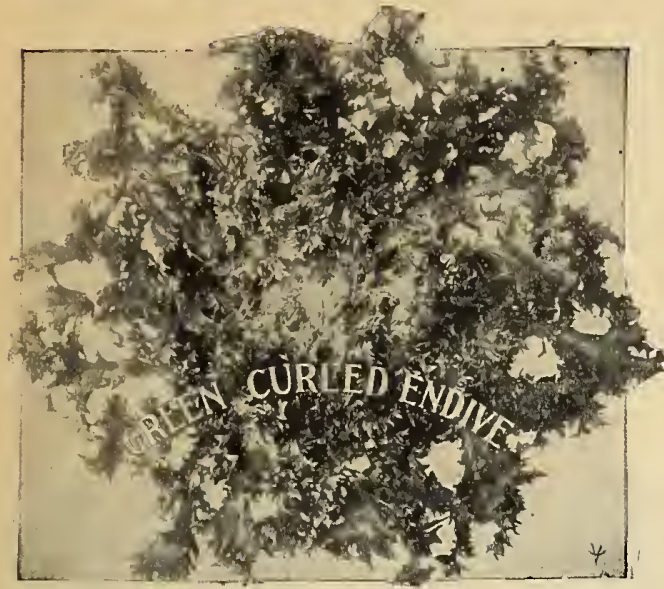

\section{HERBS}

Very short. Write for pound prices. Wurzhurg, Bavaria, and has heen grown in an old German

\section{EGG PLANT}

Vaughan's Improved New York Large Purple

Very large and smooth, fine dark color. Ours is the spineless kind, most preferred hy our market gardeners, hotl east and west. We have made the most careful selection possihle of our stock plants, and know this sort is unsurpassed for the $1 / 2$ oz., 20c.

Black Pekin. Lb., $\$ 3.00$; $1 / 4$ lb., 80c; oz., 25c.

Very Early Dwarf. Earliest of all: it re$20 \mathrm{c}$; $1 / 1 \mathrm{lb}, 65 \mathrm{c}$; $1 \mathrm{~b}$ ork in s.

\section{Black Beauty}

From 10 to 12 days earlier than New York Improved Purple. The fruits are broad and thick, of most attractive form, and of the finest flavor. The skin is a rich, purplish black,
entirely free from spines or thorns. The entirely free from spines or thorns. The fruits set most freely and are ready to market early, so that the entire crop can he gathered
before there is any danger of frost. $1 / 2$ oz., 20c oz., 35c; $1 / 4$ lb., $\$ 1.00 ; 1 b$., $\$ 4.00$.

\section{ENDIVE-Endivien}

Staghorn. Best for early. . $\$ 0.10 \stackrel{1 / 4}{\$ 0.30}$ Green Curled Summer ... $\quad .10$ Green Curled Winter. Moss, very fine curled Ever White Curled..........

Lb. Oz. Lh. Oz

Balm

Bohnen Kraut . ............

Borage (Gurkenkraut)

Wormwood..............
Anise.

S0.10

.15 30c; pkt., 10c.

Bene.

Caraway.

Pennyroyal..... Pkt., 10c; $1 / 2$ oz., 35c.

Pimpinella.

Rosemary

Sage.

$\ldots \ldots \ldots$

.30

Catnip or Catmint....

Chives....

$\$ 0.75$

Dill ..............

Fennel Sweet.

.60
.10
.10

.10

Plants.

doz., $85 \mathrm{c}$.

Summer Savory......

Sweet Mar joram........

Tarragon Plants.

doz, $85 \mathrm{c} ; 100$ for $\$ 6.00$

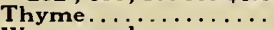

Hyssop

Lavender Spica
Short-leaved Early Erfurt
.30

.10

.15

.30

20
Broad Scotch...

Large Musselburg. . .

Rowen Large Winter.

\section{LEAF VARIETIES}

\section{GRAND RAPIDS FORCING}

The hest forcing Lettuce for Western Markets. Very hardy, grows large, and its handsome appearance gives it a ready sale. Keeps from wilting longer than other sorts.

Vaughan's Extra Selected Stock. Oz., 10c; 1/4 lb., 30c; lb., \$1.00; 5 lbs. $\$ 4.25$.

Ordinary Stock. Oz., 10c; 1/4 lb., 25c; lb., 85c; 5 lbs., $\$ 3.25$.

\section{BLACK SEEDED SIMPSON}

\section{Vaughan's Selected Stock}

This is hy far the most popular sort among the Chicago gardeners. It forms large, loose leaves of ideal color; the leaves are large, thin, very tender, and of very good quality. It it one of the hest sorts for use under glass as well as for early outdoor planting. As this kind varies when growing we have our stock seed all hand picked. Lb., \$1.00; $1 / 4$ lb., 30c; oz., 10c.

Black Seeded Simpson. Regular Stock. Oz., 10c; $1 / 4$ lb., 25c; lb., 80c.

\section{OTHER LEAF SORTS}

Oz.
Prizehead. Center portions of crinkled leaves hrown...\$0.10 Early Curled Silesia. Dwarf crisp golden leaves....... .10 Early Curled Simpson. White seeded. A fine sort..... .10 Tilton's White Star. Black Seeded Simpson type. Used for forcing. . . . . . . . . . . . . 10 Denver Market Forcing. A loose heading sort......... The Morse. A förcing selection of Black Seeded Simpson .10
$1 / 4$ Lh. Lb. $\begin{array}{ll}.25 & .80 \\ .25 & .80\end{array}$ 85 $\begin{array}{ll}.25 & .85 \\ .25 & .80\end{array}$ 25.80 $\$ 0.25 \$ \$ 0.80$
Early White Vienna.

Early Purple Vienna.

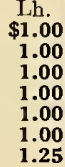

1.25

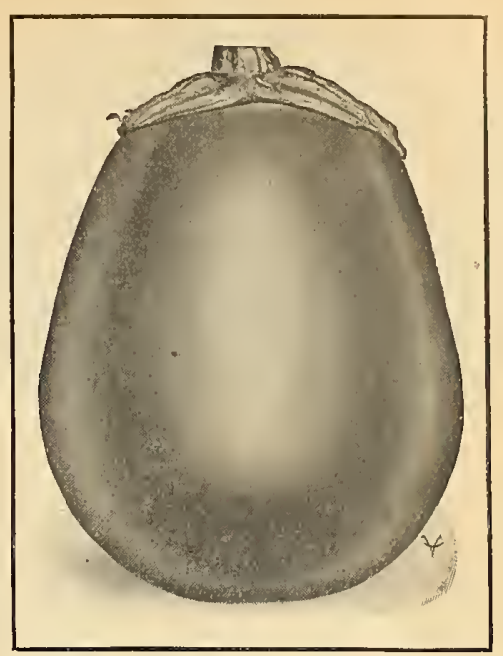

Improved New York, The Standard Variety.

\section{HORSE RADISH}

Horse Radish Sets. 100, 65c; 500, $\$ 3.25$; $1,000, \$ 5.00 ; 5,000$ for $\$ 25.00$.

Maliner Kren, New Bohemian Horse Radish. 100 roots, $75 \mathrm{c} ; 500, \$ 3.25 ; 1,000, \$ 6.00$.

\section{KOHLRABI}

\section{LEEK}

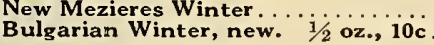

\begin{tabular}{rrr} 
Oz. & $1 / 4$ Lb. & \multicolumn{1}{c}{ Lh. } \\
$\$ 0.20$ & $\$ 0.65$ & $\$ 2.50$ \\
.20 & .50 & 2.00 \\
.20 & .50 & 2.00
\end{tabular}

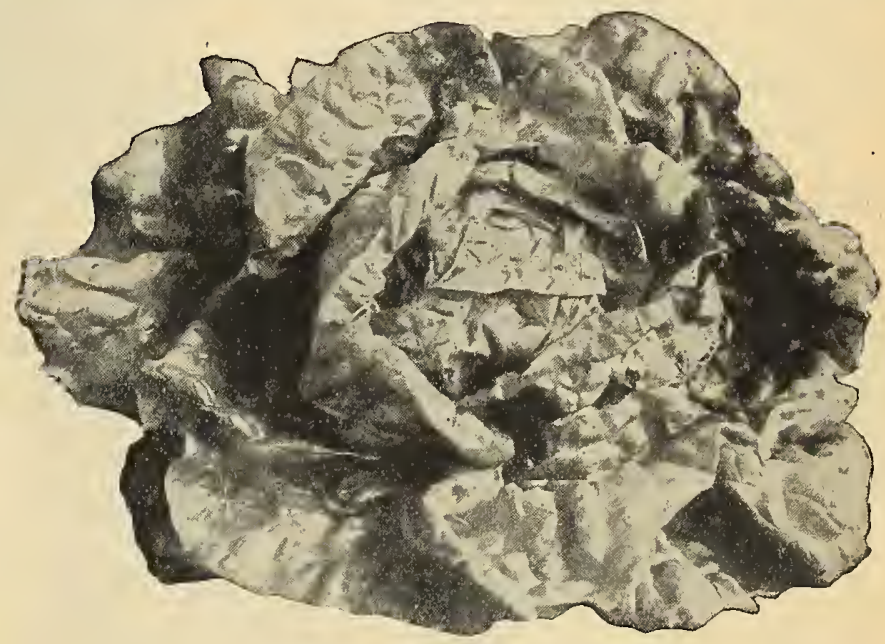

Vaughan's All Seasons Lettuce.

\section{VAUGHAN'S ALL SEASONS LETTUCE}

Re-selected Stock.

This lettuce is the best of All Head Lettuces. Known every where from its large solid head and desirahle color. Market gardeners who have purchased this seed from other sources always come to us the next season for the true stock. We have been, very careful in secd selection and this year we are offering a specia re-selected 


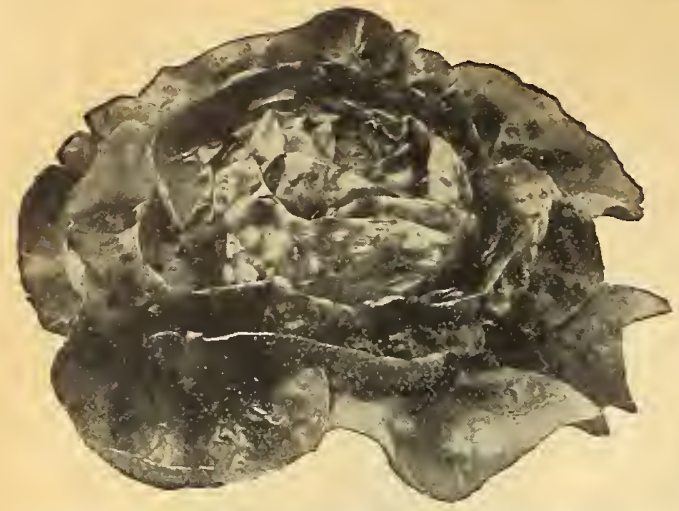

BIG BOSTON-Vaughan's Selected Stock

The best large heading, early variety. The most popular variety for the Southern gardener who ships Plants are large, vigorous; leaves are bright, light green, in the South will plant only Vaughan's Big Boston. Oz. 10c; 2 oz., 15c; $1 / 41$ lb., 25c; 1b., $\$ 1.00$.

May King. The best extra early head Lettuce. a brown tinge, oz., 10c; 1/4 lb., 30c; lb., $\$ 1.00$.

\section{LETTUCE}

Wayahead. A large extra early Head LetOz., 10c; 1/4 lb., 25c; lb., \$1.00.

St. Louis Butterhead. The head is large cabbage rith beautiful crumpled, yellow inside leave of the finest quality. An especially fine strai
this variety. Oz., 10 c; $1 / 1 / 1 \mathbf{l b}$., 20c; Ib., 80 c.

Improved Hanson. The most planted of good heat resister which forms large, firm heads with broad leaves, crumpled and exceedingly tender and
crisp. In the central corn sections the best purpose variety. Oz., 10c; 1/4 lb., 20c; 1b., 80c. The Deacon. A very sure heading, buttery to a beautiful golden yellow and is of fine flavor. Oz., 10c; 1/4 1b., 20c; 1b., 80c.

Maximum or Immensity. A popular especially in the East. Very large, solid heard and a
good heat resister Oz., 10; 1/4 1b., 25c; 1b., \$1.00.

\section{CABBAGE OR HEADING VARIETIES}

\section{MUSK MELON}

\section{Netted Gem-Rocky Ford-Selected Stock}

This seed is carefully grown, selected and saved at Rocky Ford under the care and supervision of one of the mose careful shippers. It is well known that much seed offered as Rocky Melons by men who know nothing of the responsibility of the seed business. Careful planters should avoid such stock.

VAUGHAN'S SELECTED STOCK. From best melons in field. Oz., 15c; 1/4 lb., 40c; lb., \$1.50.

REGULAR STOCK. Seed from entire field planted only for seed. Oz., 10c; 1/4 lb., 20c; 1b., 60c.

VAUGHAN'S HOODOO MELON. (Introducer's Strain.) As like as peas in a pod. The finest of the Green type of Salmon two. Slightly smaller and rounder than a Rocky ford. Nearly very fruit is of uniform high quality and sweetnes

Regular Stock, oz., 10c; $1 / 4$ lb., 25c; lb., 80c.

THE OSAGE GEM. Early as Netted Gem; same size and

Price, oz., 10c; $1 / 4 \mathrm{lb}$., 30c; lb., $\$ 1.00$.

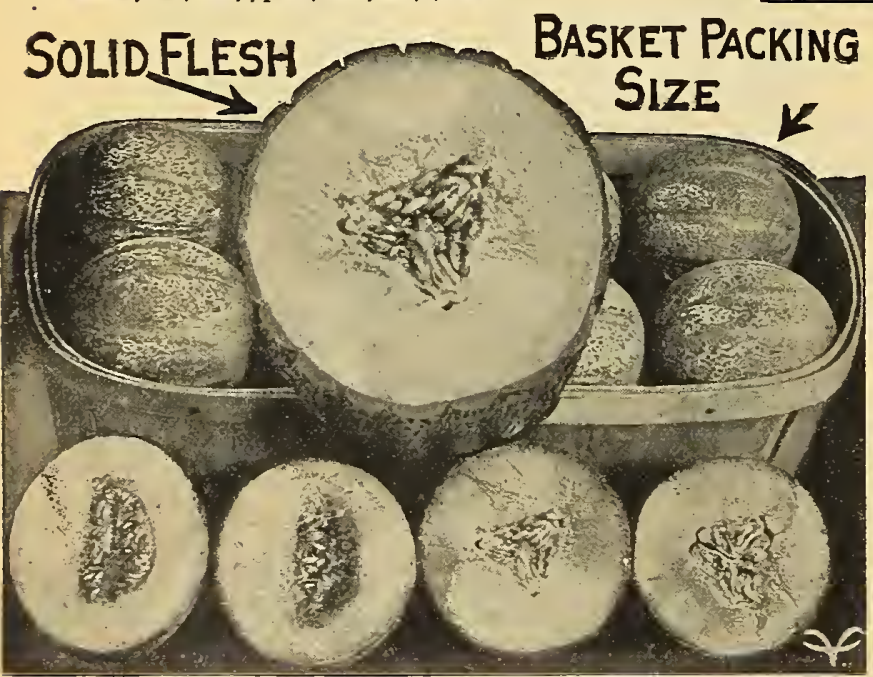

VAUGHAN'S PAUL ROSE or PETOSKEY

The best and most uniformly high quality table Melon introduced in ten years. This is a cross of the Osage with the Netted Gem, and combines the firmness of meat, salmon color, and cheesy structure peculiar to the Osage. In this respect it is superior to any Melon in existence, because of this thick, down" in keeping, retaining its form twice as long as any other shipping Melon. Vaughan's Selected Seed, oz., 20c; 2 oz., 40c; $1 / 41 \mathrm{lb}$., $60 \mathrm{c} ; 1 \mathrm{~b} ., \$ 2.00$. Regular Stock, 0z., 10c; 1/4 lb., 25c; lb., 80c.

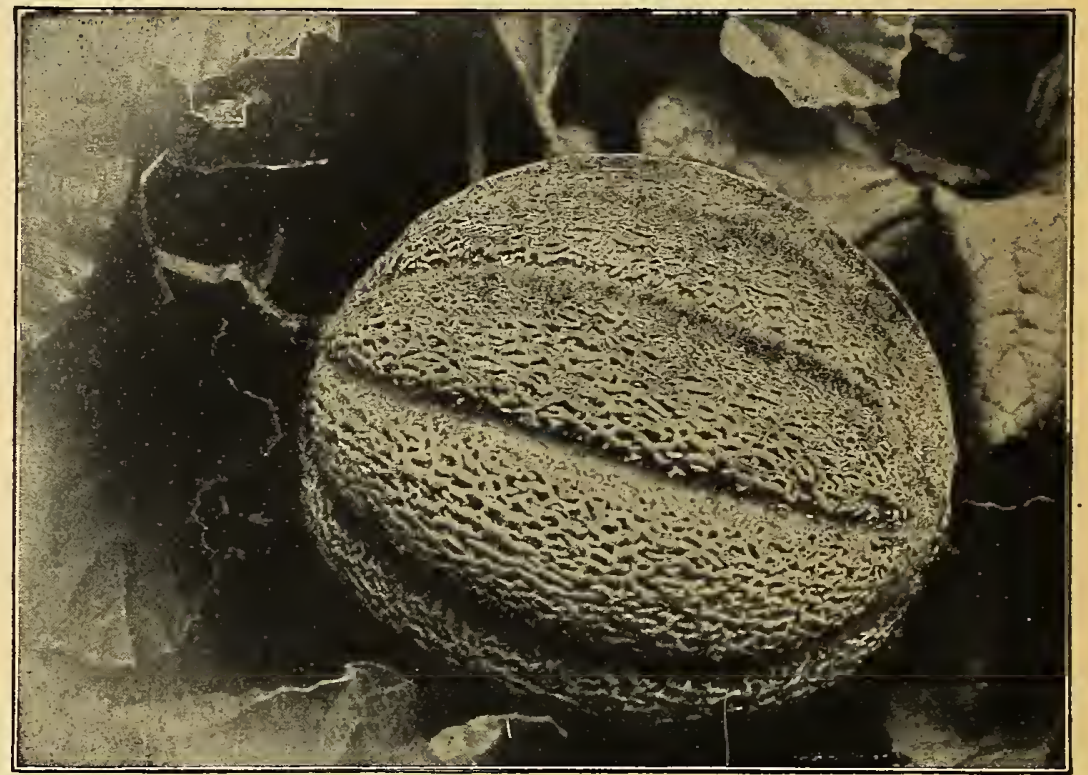

Rocky Ford Musk Melon.

\section{VAUGHAN'S ORIGINAL OSAGE}

This famous Melon is our own introduction, and we take special pride in maintaining the quality and superiority of our stock. We pay many times the prices given merchantable early MIelons. Seed obtained from culls left in the field after marketing is over can be bought cheaply, but is high at any price. However, seed taken from early choice market melons must bring a high price, though really a hundred times cheaper than the other. Salmon flesh, high table quality; during the last season was the best Melon on the Chicago Market. Our strain is dark skinned, but netted.

Vaughan's Selected Stock. Oz., 20c; 2 oz., 35c; 1/4 Ib., 65c; lb., \$2.25.

Regular Seed. Entire field grown for seed, but seed not chosen from special melons. Oz., 10c; 1/4 lb., 25c; lb., 80c.

Osage, Special Shipping Strain. Slightly more netted than Oz. $1 / 4 \mathrm{lb} . \quad \mathrm{Lb}$.

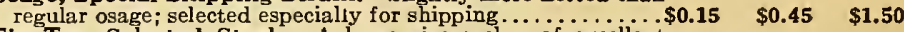
$\begin{array}{lllll}\text { Tip Top, Selected Stock. A large size melon of excellent } & & & & \\ \text { Tip } & \mathbf{3 0} & \mathbf{1 . 0 0}\end{array}$ Extra Early Hackensack. An early selection of Hackensack. Melons large, weight 4 to 10 lbs. Well netted, green flesh, .10 $\begin{array}{llr}10 & .25 & .75\end{array}$ $\begin{array}{lllll}\text { Emerald Gem. Dark green, early melon. Delicate salmon } & 10 & .30 & 1.00\end{array}$ fiesh. Not good for shipping. Of high table quality $\ldots . . . .$.
Milwaukee Market. For local market use, nothing better. Salmon flesh, good size. Is not a good shipper...................

Vaughan's Chicago Market. A large, early nutmeg.

Oval Gem. The Eastern grown Rocky Ford.

Extra Early Nutmeg. Smail and early

Early Citron. Landreth's Early Flat, fair quality

Jennie Lind, Improved. A flattened, good shipping variety Montreal Market. The largest of 'Nutmegs .

Round Gem. The standard round Netted Gem..............

Mango Melon, or Vegetable Peach. . For pickles and pre-

Forcing Melons, Emerald Gem Forcine A1 Superb, Bestof A Dis.s. Blenheim Orango. Diamond Jubilee, Invincible Scarlet, Royal Sovereign. Trade pkt., each 25c. 


\section{VAUGHAN'S LIVE MUSHROOM SPAWN}

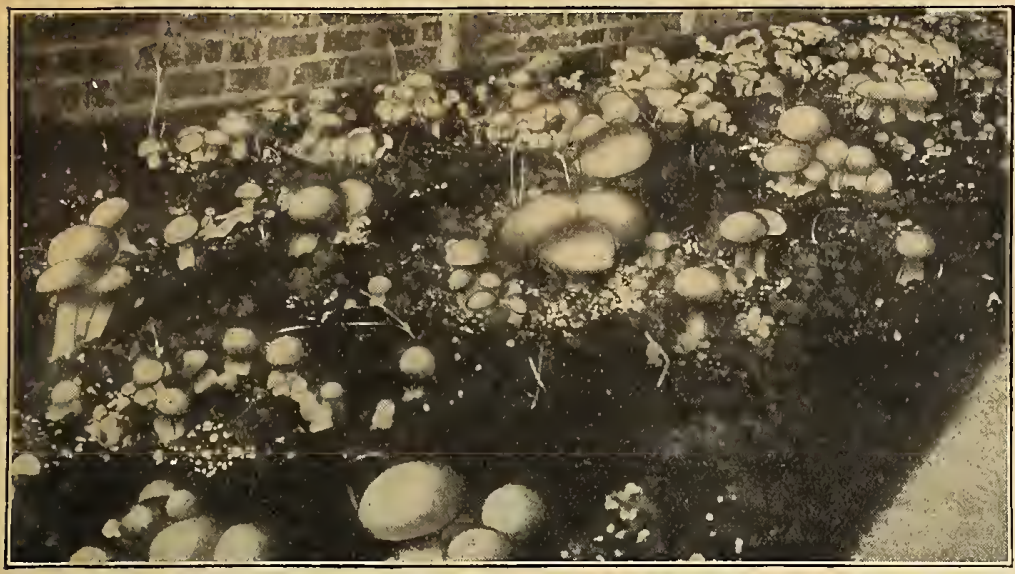

Make Bed in Basement or any Out-Building-Temperature 550 to 650 Fahrenheit

Vaughan's English Mushroom Spawn. Our Spawn is manufactured by the largest and most successful maker of Spawn in the world. He has made Spawn for some thirty years and has kept up on all the new methods of manufacture. Our Spawn is made by the famous tissue method from selected specimens. It has been found that English Spawn, as a rule, does not bear so quickly as the American pure culture, but it, however, lasts longer in bearing.

Price: (Weight per brick, 11/4 lbs.), brick, 15c; 2 bricks, 25c; 8 bricks, $\$ 1.00 ; 25$ lbs., $\$ 2.00$; 100 lbs., $\$ 7.00$; if shipped from New York $\$ 6.50$ per $100 \mathrm{lbs}$. Special prices on $1 / 2$ ton lots and upward.
The growing of mushrooms has now become a standard business and there are many successful growers in all parts of the country. Better culture and better apawn are the causes of the change from a speculative to a standard crop. Vaughan's Sced Store has been very successful in supplying both the American Pure Culture and the imported English spawn. We receive monthly shipments of American and sir monthly shipments of English spawn from our manufacturers, so our spawn is always fresh.

\section{LAMBERT'S PURE CULTURE SPAWN}

Lambert's Pure Culture Spawn. This is made in America from selected Mushrooms grown under cultivation. The bricks are inoculated with tiny threads from a young specimen fruit, so that the special sorts are produced truc to type, theoretically, in practice they sun nearly true to type. American Spawn is much presher than English as it is not necessary to dry out the bricks for a long transportation trip.

Order by number. The following now run nearly true to type. The Whites and Cream-Whites are the most popular market sorts.

5. Brown (Bohemia) prolific, grows in clusters.

6. White (Alaska) similar to 9 but with heavier stem.

7. Brown (Bohemia) hardy, good producer, very heavy

8. Cream-White, hardy, prolific, preferred for summer planting.

9. White (Alaska) a market favorite.

10. Light Brown (Bohemia) heavy, quite fleshy

11. Cream (Columbia) similar to 8 , but larger and slightly darker

12. Cream (Columbia) large and very fleshy.

Price: Direct Bricks (weight 11/4 lbs. per brick), inoculated from laboratory cultures. Brick, 30c; 5 bricks, \$1.25; 10 bricks, \$2.00; 25 bricks, $\$ 4.25 ; 100$ bricks, $\$ 15.00$.

Standard Bricks (weight 11/4 lbs. per brick) inoculated from direct bricks (weight 11/4 lbs. per brick). Brick, 25c; 5 bricks, $\$ 1.00 ; 10$ bricks, $\$ 1.85 ; 25$ bricks, $\$ 3.75 ; 100$ bricks, $\$ 12.00$.

In watermelons for market there has been a considerable change in varieties the past few seasons due to the introduction of the Alabama Sweet and Tom Watson, good shipping varieties of the long type melon, a type long associated with high quality but heretofore too poor shippers. Growers who intend to ship carloads a way to market should be careful to find out what their receiving market demands.

Kleckley Sweets. The quality melon for home and local market. Without doubt this is the highest quality melon both as to texture, firmness with no stringiness, and sweetness, in which respect it has no equal of all melons on the market today. In shape it is oblong, of good size, skin today. In shin dark green, fesh bright scarlet, ripening close to the skin. The large heart does not crack open when ripe. Its one fault is that the shell is thin 1/4 $\mathrm{lb}, 25 \mathrm{c}$; 1b., 75c; $5 \mathrm{lb} ., \$ 3.25$.

Alabama Sweets. A popular, rather new, long oblong melon with hard shell, which makes it a good shipper. In color dark green, size large and districts. Select stock. Oz, 8c; $1 / 4 \mathrm{lb}, 20 \mathrm{c} ; \mathrm{lb} ., 60 \mathrm{c}$

Vaughan's Black Diamond. Its prominent points of merit are its extreme size and productiveness. Melons weighing 75 to 90 pounds are frequent. It is the most prolific Water Melon. Its color is a rich, dark green, almost black. Oz., 7c; 1/4 lb., 15c; lb., 50c; 5 lbs., \$2.25.

Sweetheart. A standard shipping melon of the round type. Vine vigorous and productive. The melons are large, uniform and heavy, mottled light and dark green. Oz., 7c; $1 / 4$ lb, $15 \mathrm{c} ; \mathrm{lb} ., 40 \mathrm{c} ; 5 \mathrm{lbs} ., \$ 1.85$.

Improved Kolb's Gem. The best known shipping melon of the old type. Color, dark with yellow blotch on bottom. Oz., $5 c ; 1 / 4$ lb., 15c; lb., 40c; 5 lbs., \$1.85; 10 lbs., \$3.25.

Triumph. One of the largest and handsomest of the large round shipping melons. Dark green. Oz., 7c; 1/4 lb., 15c; lb., 40c.

Winter Water Melon (Novelty). A small round light colored melon of high quality, which can be kept until Christmas. Pkt., 10c; oz., 20c; 2 oz., 35c; $1 / 4$ lb., 50c; lb., $\$ 2.00$.

New Chilian. Nearly round melon, ours is the early strain. A very fine flavored melon; something different and attractive for local market. $\mathrm{Oz}, 10 \mathrm{c} ; 1 / 4 \mathrm{lb}$ 30c; lb., \$1.00.

7c the ounce on any of the following:

$1 / 4 \mathrm{lb}$. $\mathrm{lb}$

Citron, red seeded . . . . . .20 .60

Colorado Citron..........20 .60

Cuban Queen ............20 .60

Dark Icing . . . . . . . . . . 15

Dixie...................

Duke Jones. . . . . . . . . . . . . 15

Florida Favorite...........15 .50

Early Fordhook ...........20
$1 / 4$ lb. lb.

Rattlesnake............. $15 \quad .50$

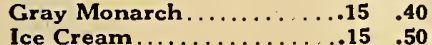

Jones' Jumbo. . . . . . . . . ...15 .40

Peerless................ $15 \quad .50$

Phinney's Improved . . . . . . $15 \quad .40$

Mountain Sweet ..........15

McIver's Sugar

White Velvet.

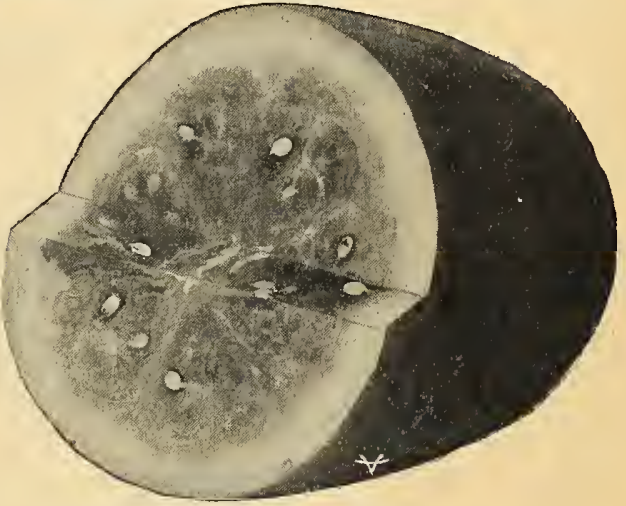

TOM WATSON

Water Melon Tom Watson. Considered one of the most important introductions of recent years. A variety which has in the last few years become the most popular of all shipping melons. In appearance it resembles somewhat the Kleckley Sweets except that it is much fuller at the ends. Its extreme value is in its shipping qualities. The rind is very thick and growers prefer this variety to Keckley's or Halbert Honey for shipping to a long distance. The fruits are cylindrical in shape and the rind is a dark green. The flesh is a deep red, very sweet and melting. Oz., 10c; $1 / 4$ lb., 25c; lb., 75c; 5 lbs., \$3.25.

\section{COLE'S EARLY}

Cole's Early. This is the best Early Water Melon for the home market. For sweetness and delicate texture of flesh it has no equal in the earlies. The rind is thin and brittle, and therefore this variety is not suitable for shipping. We have an extra early strain. Oz., 10c; $1 / 4 \mathrm{lb}$., 20c; lb., 60c; 5 lbs., $\$ 2.65$.

\section{MARTYNIA FOR PICKLES}

The young and tender seed pods make a very fancy pickle. Oz., 15c; $1 / 4 \mathrm{lb}$ 40c; lb., \$1.50.

White London

MUSTARD

Brown

New Chinese.

Fordhook Fancy

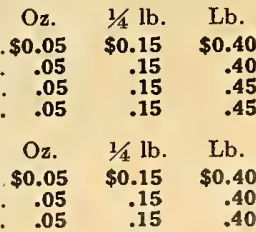

Tall (Perkin's Mammoth)

OKRA

.05

.




\section{VAUGHAN'S PEDIGREE ONION SEED}

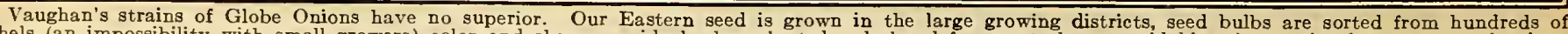

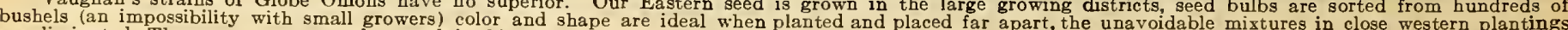

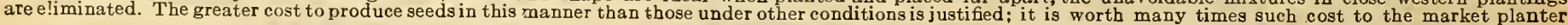

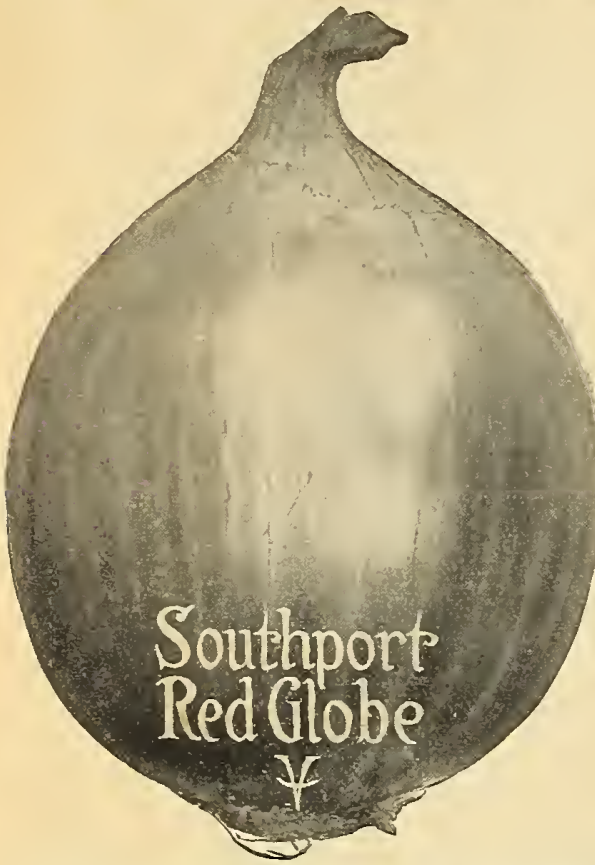

Southport Red Globe.

Has a beautiful dark red skin; the onions ing them first sellers and excellent keepers.

Yield $\rightarrow 800$ to 1,000 bushels per acre is not uncommon with our seed. It is rown under our supervision by a specially equipped expert in this line.

Eastern grown, $\mathrm{Oz} 20 \mathrm{c}, 1 / 4$ lb 65c, lb $\$ 2.50,5$ lbs $\$ 12.00,10$ lbs $\$ 23.00$. Western grown, Oz 15c, 1/4 lb 55c, lb \$2.00, 5 Ibs \$9.50, 10 lbs $\$ 18.00$. Ohio Yellow Globe. (Sce illustration.) Best of all yellow onions. Danvers. Earlier, smaller necked, perfect globe shape, uniform as to size and color and a greater cropper. Vaughan's Special Ohio-grown Seed of this type is an extra fine selection of this most excellent sort, for color, shape and yield Seed growers regard it the superfine strain of yellow Onion Seed. Eastern grown $\mathrm{Oz} 25 \mathrm{c}, 1 / 4 \mathrm{lb} 70 \mathrm{c}, 1 \mathrm{lb} \$ 2.75,5$ lbs. $\$ 13.25,10$ lbs $\$ 25.50$. Western grown, $\mathrm{Oz}$ $20 c, 1 / 41 b 60 c, 1 b \$ 2.25,10$ lb. lots and over $\$ 2.15$ per lb.

Ohio Red Globe. A very uniform Red Globe Onion similar in shape grown by the originator. Oz 20c, 1/4 Ib 65c, Ib $\$ 2.50 .5$ lbs $\$ 12.00,10$ lbs $\$ 23.00$. Vaughan's Apple Shaped Red Globe. The most perfect Red Globe Onion. Ideal shape for maximum yield. Color is absolutely darkest blood-red. Its size equals any of the largest types of Red Globe.

History- first planted in the west (1896) under the name of Extra Early Red Globe, grown on rich land; carefully selected for size, carefully selected for size,
shape and color, improved shape and color, improved believe it is the best of its class. Oz 20c, $1 / 4$ lb $65 \mathrm{c}$, Ib $\$ 2.50,5$ Ibs

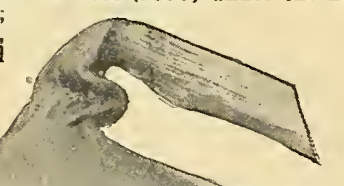

VAUGHAN'S

APPLE SHAPED

RED GLOBE

ONION

\section{Mammoth Silver King.}

The largest of the white Onions. Specimens weigh 2 to 4 pounds each. Mild flavor. Fine for fancy market. Oz 20c, $1 / 4 \mathrm{Ib}, 60 \mathrm{c}$ Ib $\$ 2.00$.

Ailsa Craig. Vaughan's Re-Selected A better keeping and Seed. Very short crop. ping and larger Onion than Prizetaker. Unexcelled for exhibition. Sow early in hotbed and transplant. Pkt 15c, 1/2 oz Bermuda Onions. Ours is true Grown Seed of these popular southern o riff $\left.\begin{array}{l}\text { White Bermuda } \\ \text { Red Bermuda } \\ \text { Crystal White Wax }\end{array}\right\}$ Sold out

NITRATE OF SODA or Chili Saltpeter For Onions, a top dressing of from 75 three times t intervas $100 \mathrm{lbs}$. per acre two or may be used after the roos have well started For Nitrate of Soda, Muriate of Potash and Vaughan's High Grade Truck and Farm Manure, see page 27.

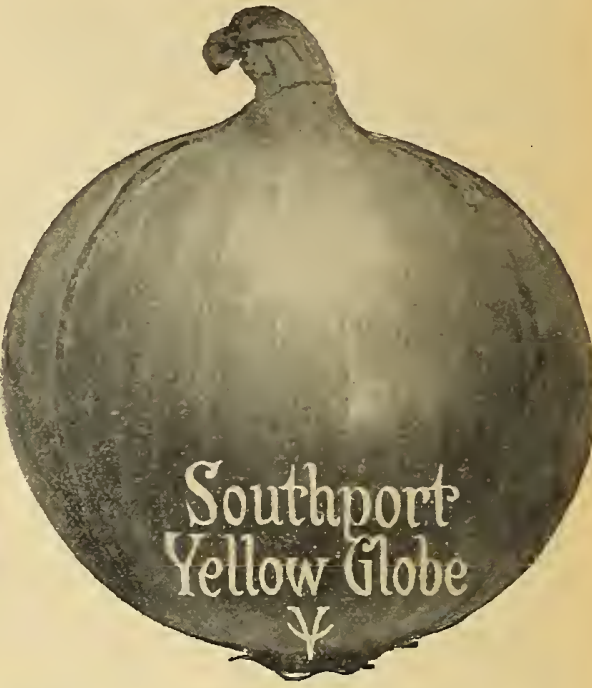

Vaughan's Ideal White Globe Onionis omeness personified; true globe form, pure white, hard, mall necked, ripens very early, evenly and is a good keeper. west. Don't plant inferior stock with only low price to recom mend it; it is far more expensive than our high Eastern grown, Oz $35 \mathrm{c}, 1 / 4 \mathrm{lb} \$ 1.10$, Ib $\$ 4.00$ Will satisfy the small buyer or the Best of all yellow onions for keeping. Our Eastern strain comes from a growe

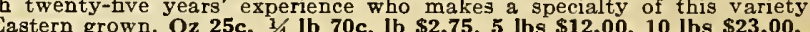

\section{PRIZETAKER ONION}

Vaughan's Selected Stock. Handsomest and largest yellow Globe Onion. Fair keeper, of finest flavor 等 morted) seen in fruit stores. Always commands a high price.

Prizetaker nearly always grows to a perfect globe shape with a bright straw grown seed. Oz 20c, $1 / 4$ Ib 60 , Ib $\$ 2.00 .5 \mathrm{lbs}$

Australian Brown Globe. A very maturing variety. Bulbs are good size, very solid. Keeping quality excellent, one of the The onions are thin necked and ripen evenly

thin necked and ripen evenly n 1 oz 20c $1 / 4$ lb 60c, lb $\$ 2.25,10$ ways ripen up hard. American
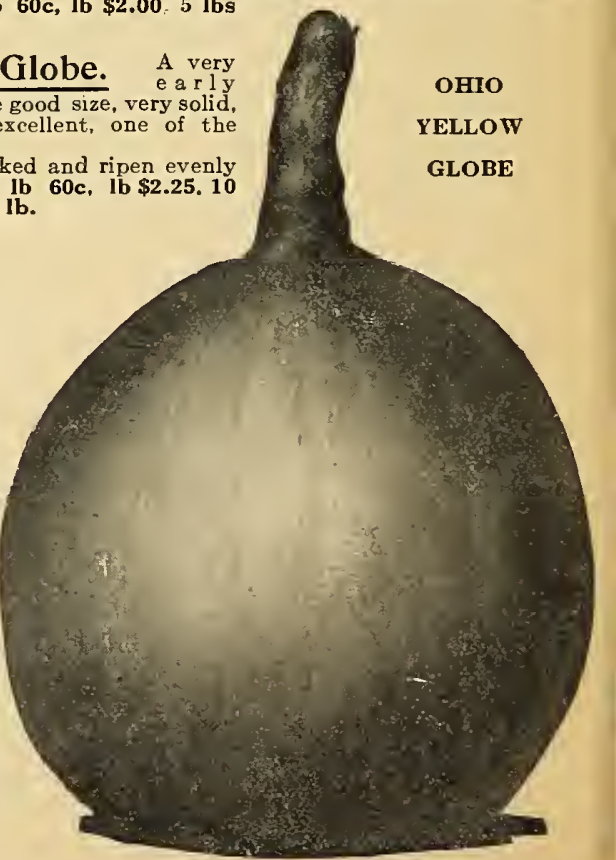


\section{VAUGHAN'S PEDIGREE ONION SEED}

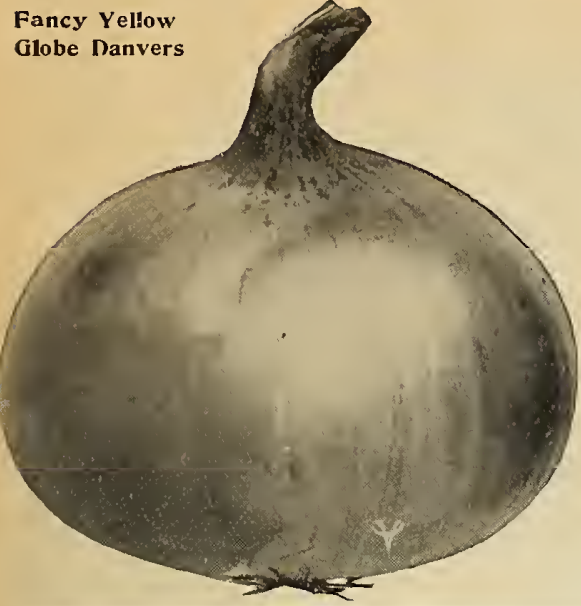

“Fancy" Yellow Globe Danvers. The shape is uniformly round; color a fine brown, orange yellow. gardener can afford to experiment with doubtful seed. Oz., 20c; 2 oz., 35c; $1 / 4$ lb., 60c; lb., $\$ 2.25 ; 10$ lb. lots and over \$2.15 per $\mathrm{lb}$.

Yellow Globe Danvers. This strain of Globe Danvers is equal to any usually sold and may be relied and over $\$ 1.90$ per $\mathrm{lb}$.

Early White Welsh Onion. For Green Onions. This kind does not form a bulb, but is one of the

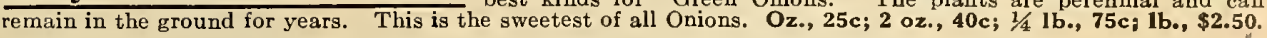

\section{EARLY MILD ONIONS. European Grown.}

Vaughan's Pickling. This is a uniform early small round, hard, crisp, tender and very handsome

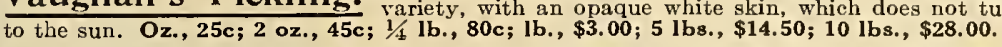

White Queen. Remarkable for its earliness and very mild flavor; it is small and white skinned. Every oz., 20c; 1/4 lb., 65c; lb., $\$ 2.45 ; 5 \mathrm{lbs}$., $\$ 11.75 ; 10 \mathrm{lbs}$., $\$ 22.50$.

White Barletta. It is a beautiful waxy-white color, much admired by housewives. Price, same as that of White Queen. Oz., 20c; 1/4 lb., 65c; lb., \$2.45; 5 lbs., \$11.75; 10 lbs, $\$ 22.50$

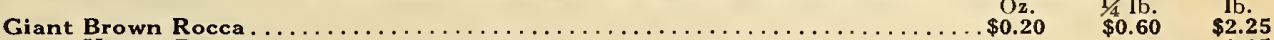
Giant Yellow Rocca...

\section{From Carefully Selected Seed Bulbs

Our Onion Set Seed is strictly California-grown from carefully selected bulbs. We particularly pride ourselves on germination-due to up-to-date cleaning machinery. Every bag must test satisfactorily before it leaves our establishment.

\section{FLAT ONION SET SEED.}

White Portugal or Silverskin. A large flat onion of mild flavor skin glistening like silver. A favorite with many for at beauty, its clear white or bunching onion, and for pickles. It is also a good keeper and fine for fall and early winter use. Oz., 25c; $1 / 4 \mathrm{lb}$., $85 \mathrm{c}$; $1 \mathrm{lb}$., $\$ 3.10$; $10 \mathrm{lb}$. lots $\$ 3.00$ per $1 \mathrm{lb}$ Philadelphia Silverskin. Special strain of White Portugal. Oz., Large Red Wethersfield. This is the standard Red Flat Variety; somewhat flattened; flesh, purple-white; moderately fine grained, and stronger fomewh than any of the other kinds. It is more inclined to form large necks, if planted on unsuitable soil, than the Danvers, but it is the best variety on poor or dry soil. Oz., 20c; $1 / 4 \mathrm{lb} ., 60 \mathrm{c}$; 1b., $\$ 2.30 ; 10 \mathrm{lb}$. lots $\$ 2.20$ per lb.

Extra Early Flat Red. Ours is an especially early dark red strain, careonion. Oz., 20c; 1/4 Ib., 60c; 1b., $\$ 2.30 ; 10 \mathrm{lb}$. lots $\$ 2.20$ per $1 \mathrm{lb}$.

\section{FLAT YELLOW SORTS.}

Strassburg or Flat Dutch. A standard flat yeliow onion. Flesh onion. Oz., 20c; 1/4 lb., 60c; 1b., $\$ 2.10 ; 10 \mathrm{lb}$. lots $\$ 2.00$ per lb.

Yellow Danvers. A fine productive variety of medium size; skin, coppery Ib., \$2.10; $10 \mathrm{lb}$. lots and yellow. Excellent for yellow sets. Oz., 20c; 1/4 1b., 60c: Australian Brown Flat. The longest keeping flat onion. Extra early used for "Brown Sets." Oz., 20c; $1 / 4 \mathrm{lb}$., 60c; $1 \mathrm{~b}$., $\$ 2.10 ; 10 \mathrm{lb}$. lots and over $\$ 2.00$ per $\mathrm{lb}$.

Yellow Cracker. The earliest flat yellow; desirable in climates where sealots and over $\$ 2.00$ per $1 \mathrm{~b}$. Bolton. The ideal set onion. Brown color, sell for yellow, early maturing, $\mathbf{l b . ,} \$ 2.10 ; 10 \mathrm{lb}$. lots and over $\$ 2.00$. per $\mathbf{l b}$.

\section{ONION SETS}

Onion sets are subject to market changes, and while we shall try to maintain these prices, we cannot guarantee them to last throughout the season and advise early orders.

These are the product of seed and are used for "Green Onions" or to produce large Onions, which they do much more quickly than can be grown from seed. Our sets are small, dry and unsprouted.

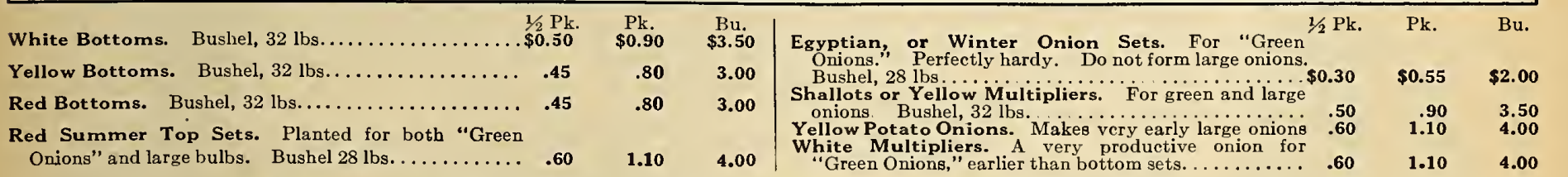

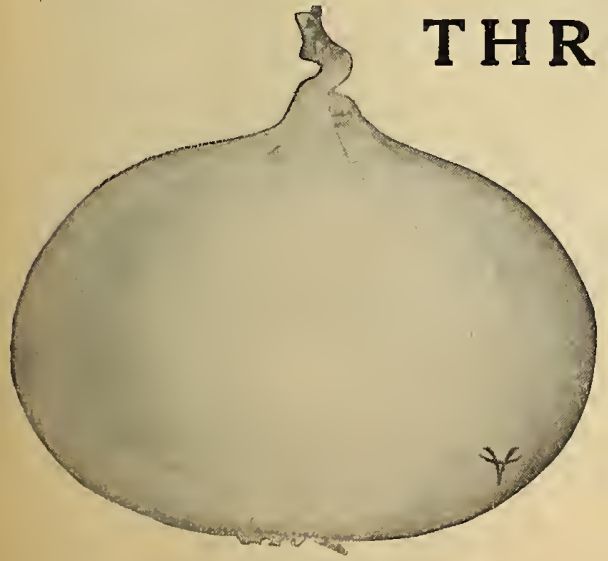

WHITE PORTUGAL

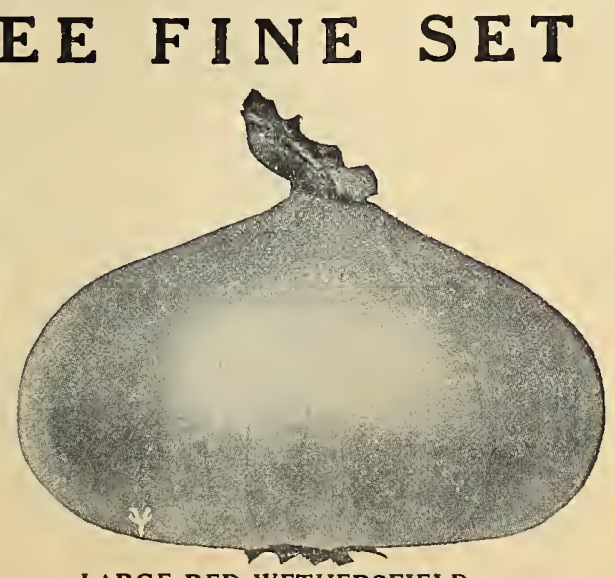

LARGE RED WETHERSFIELD
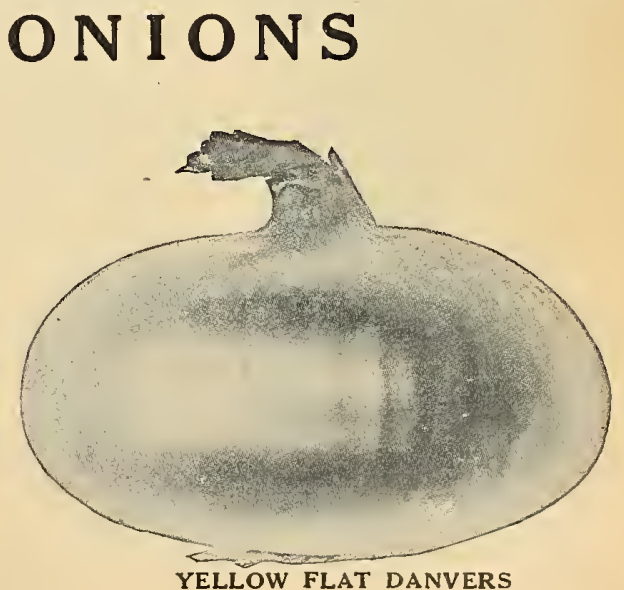


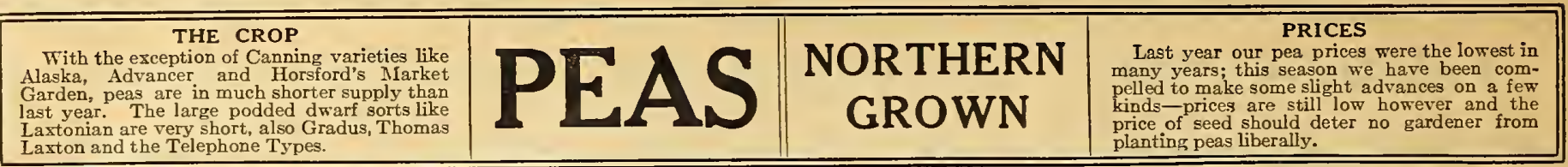

\section{EXTRA EARLY TALL SORTS \\ GRADUS-VAUGHAN'S RE-SELECTED STOCK}

Gradus is the best extra early wrinkled pea for the market gardener. It is twice as large. The pods are so large that they sell for Telephones on the market. The quality is unsurpassed and our stock is always top-notch. Continual reselection is necessary to keep this pea free from small pods and runners. Beware cheap strains, they cannot be good. Qt. 30c; 1/2 pk. 90c; pk. $\$ 1.75 ;$ bu. $\$ 7.00$. THOMAS LAXTON Similar to Gradus, only pods are blunt shaped instead of pointed or tapering. On the market it does not sell up to Gradus unless known. It is a better yielder however, and in ordinary
seasons the pods contain from one to two more peas. Qt., 30 c; $1 / 2$ pk., $\$ 1.00$; pk., \$1.85; bu., $\$ 7.50$.

ALASKA This is the standard market extra early. The seed is round and wrinkled pea and hence may be planted very early. In season our Alaska is as early 2 any other sort except Velocity. Pod $21 / 2$ incheslong. Uniform and even

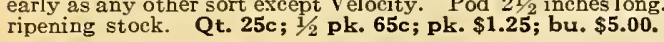

VAUGHAN'S SELECT EXTRA EARLY (MAUD S.) The early seeded round peas are generally known as the "extra earlies," and they go by many different names. Vaughan's Maud S strain is a very early, reselected stock, bred especially for uniformity in ripening so that the crop may be harvested at one picking. The pods are $21 / 2$ in. long, and the peas are of good quality, superior one picking. The pods are $21 / 2$ in. long, and the peas are of good quality, sup
to Alaska of the same season. Qt. 25 c; $1 / 2$ pk. 65 c; pk. $\$ 1.25 ;$ bu. $\$ 5.00$.

AMEER "A large podded Alaska." A few days later in season than Alaska. The pods are large, trifle smaller than the Telephone and usually sel better on the market than Alaska or Extra Early;
and the quality like Alaska. Qt. 30c; $1 / 2$ pk. 85 c; pk. $\$ 1.65 ;$ bu. $\$ 6.50$.

VAUGHAN'S NEW LATE GRADUS This new pea fills in the space the which has hitherto existed in the equal of Gradus; it has Telephone pods and yields very nearly as well. Qt. 35c; pk. $\$ 1.15$; pk. $\$ 2.25$; bu. $\$ 9.00$.

\section{OTHER EARLIES}

Velocity. Smaller and earlier than Alaska......\$0.30 Surprise. The earliest wrinkled variety ............30

First and Best. Choice extra early, white seed.. .25

$\begin{array}{rr}1 / 2 \mathrm{pk} . & \text { pk. } \\ \$ 0.85 & \$ 1.65 \\ .85 & 1.65 \\ .65 & 1.25 \\ .85 & 1.60\end{array}$

$\$ 6.50$

Premium Gem. Semi-dwarf, early wrinkled pea. $\mathbf{. 3 0}$

\section{MARKET GARDEN DWARF VARIETIES}

LAXTONIAN The Dwarf Gradus-a new giant podded, early dwarf pea; almost The pods are large and sell equally as well as Gradus, being of dwarf habit this pea may be grown between other crops and will be out of the way when other crops

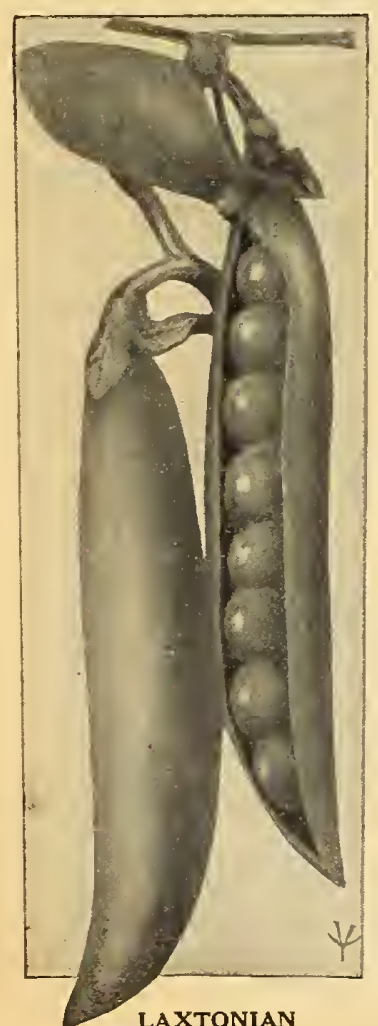
are just well started. Vaughan's Seed Store introduced this pea in America, and we are headquarters for the right stock. A low Qt. 35c; 1/2 pk. $\$ 1.25$; pk. $\$ 2.40$; bu. $\$ 9.50$. NOTT'S EXCELSIOR HeaviestyieldOt, 30c; $1 / 2 \mathrm{pk}$ $85 \mathrm{c}$; pk. $\$ 1.65$; bu. $\$ 6.50$.

SUTTON'S EXCELSIOR Large pod hardy ear tender Gradus. Qt. 35c; $1 / 2$ pk. 90c; pk.
$\$ 1.90 ;$ bu. $\$ 7.50$.

IMPROVED STRATAGEM Late, high quality, dark green pods Hard to keep straight because small podded vines grow pk. 85c; pk. $\$ 1.65$; bu. $\$ 6.50$.

\section{OTHER DWARFS}

\section{AmericanWonder $1 / 2 \mathrm{pl}$}

$\begin{array}{lllll}\text { early dwarf ....... } \$ 0.30 & \$ 0.85 & \$ 1.60 & \$ 6.50\end{array}$

Little Marvei.

proved Nott's

Excelsior, dark

pods..............
Advancer. Second

$\begin{array}{llll}30 & 1.00 & 2.00 & 8.00\end{array}$

Advancer. Second
heary yielder,

fair size pods....

Garden. Mid-

se as on, heavy
yielder.........
warf Telephone.

Dwarf Telephon
(Very short).....

Heroine. Lat e
Dwarf, good pods.

J uno or Dwarf

Champion. Late

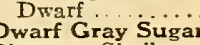

$\begin{array}{llll}30 & .75 & 1.50 & 6.00\end{array}$

Pion Gray Sugar

Laxtonian.

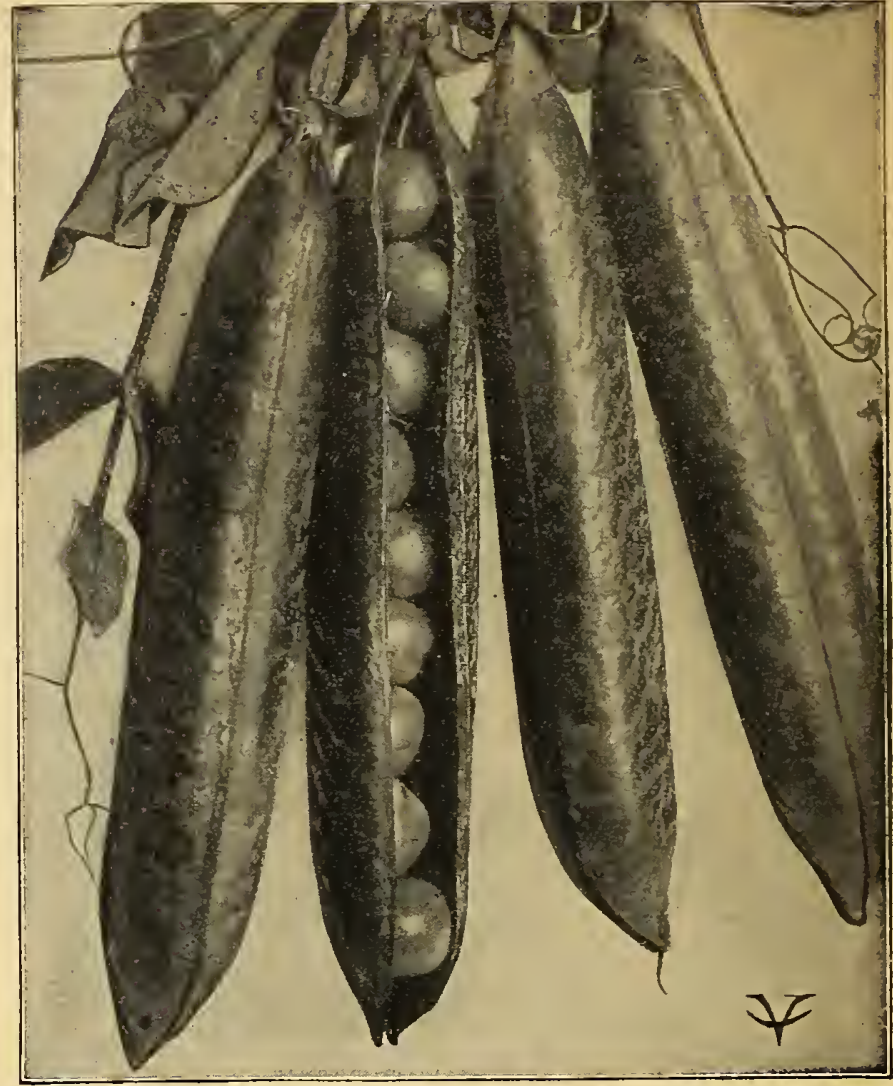

VAUGHAN'S IMPROVED TELEPHONE

\section{TELEPHONE TYPES}

The early season, heary yield, large pods, and fine flavor of Telephone Peas have placed this $\mathrm{v}$ ariety in the greatest favor for both market and home use. Following are the best selections of this popular sort:

\section{VAUGHAN'S IMPROVED TELEPHONE}

Standard high quality has been maintained for this most popular favorite, notwithstanding the unfavorable seasons of the past few years. This excellent sort has exceptional qualities, and is the best main crop. The pods immense in size, fine dark green color, more desirable than the light green of ordinary
Telephone, and they are well filled with delicious, sweet peas. Height four feet. Our stock is uniform. Qt. 30c; $1 / 2$ pk. 85c; pk. $\$ 1.65$; bu. $\$ 6.50$.

ALDERMAN Best of the Duke of Albany type. Large dark pods. Uniform Atrain. Qt. 30c; $1 / 2$ pk. 85c; pk. $\$ 1.65 ;$ bu. $\$ 6.50$.

TELEPHONE Light green colored pods, less uniform than Improved TeleTELEPHONE phone. Qt. 30c; $1 / 2$ pk. 75c; pk. $\$ 1.50$; bu. $\$ 6.00$.

ADMIRAL DEWEY Similar to Vaughan's Improved Telephone. Large dark PRINCF EDWARD IaTgest pods of the Telophone Trpe: dos not rield Pa heavy as Vaughan's Improved. Qt. 30c; $1 / 2$ pk. $85 \mathrm{c}$; pk. $\$ 1.65 ;$ bu. $\$ 6.50$.

\section{LATE OR MAIN CROP VARIETIES}

CHAMPION OF ENGLAND Tall, vigorous and an enormous yielder; a of the oldest before the public. Late. Qt. 30c; $1 / 2$ pk. 75c; pk. $\$ 1.50$; bu. $\$ 6.00$. EVERBEARING Medium height, pods 3 inches long, very prolific. Qt. 30c; EVERBEARING 1/2 pk. 75c; pk. \$1.50; bu. $\$ 6.00$.

QUITE CONTENT The largest podded of all Peas. Quite Content is an QUI English exhibition variety which does very well in the United States. The vine's habit is slighty stronger than Telephone-the pods Long Island Mammoth. A smooth seeded Tel- Qt. 1/2 pk pk. bu.

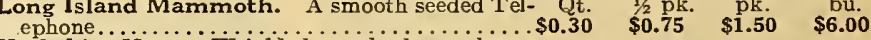
$\begin{array}{llllll}\text { Yorkshire Hero. Wrinkled standard sort; keeps } & 30 & .85 & 1.65 & 6.50\end{array}$ in good condition for a long time ..................

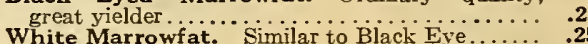

Mammoth Podded Sugar. Largest podded

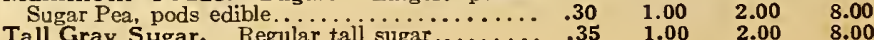




\section{P A R S L E Y}

The Champion. Is a prize-winning English variety, in appearance like a tuft of run to seed and very hardy; of easiest growth, a few seeds sown in onion rows use no space. Grows in window boxes. Oz., 10c; $1 / 4$ lb., 25c; lb., 90c.

Vaughan's XXX Parsley. An extra selected and dwarf strain of moss curled garnishing variety to be found. Its size makes it especially desirable for greenhouse and frame use. Oz., 15c; $1 / 4 \mathrm{lb}$., 40c; lb., $\$ 1.25$.

Double Curled. Oz., 10c; 1/4 lb., 25c; 1b., 90c.

Fern-Leaved. Oz., 10c; 1/4 lb., 25c; lb., 90c.

Plain. Oz., 10c; 1/4 lb., 25c; lb., 90c.

MARKET

GARDENERS'

STRAINS

Hamburg Rooted or German Parsley. The root resembles a small parsnip flavoring soups. Oz., 10c; 1/4 lb., 30c; lb., $\$ 1.00$.

\section{P A R S N I P S}

Magnum Bonum, A very fine and greatly improved strain of Hollow Crown Parsnip, roots are smooth, not so long as those of the standard sort, somewhat thicker in diameter and much more easily pulled. A very heavy cropper. Oz., 7c; 1/4 lb., 15c; lb., 50c.

Improved Guernsey. An improved strain, which has given general as those of the Hollow Crown, but are of greater diameter and more easily gathered. Of excellent quality. Oz., 7c; $1 / 4$ lb., $15 c ; 1 b ., 50 c$.

Hollow Crown, or Long Smooth. (Abbot's Improved.) Smooth, of the best. Our stock is very fine. Oz., 7c; 1/4 lb., 15c; lb., 50c.

Vaughan's Marrowfat. A thick shouldered hollow crown variety. ance gives it a ready sale. Oz., 10c; 1/4 lb., 20c; 1b., 60c.

\section{P E P P E R}

\section{Vaughan's Magnum Dulce Pepper}

Decidedly superior to Chinese Giant or any other variety known to market in size and sweet quality. The result of many years' careful selection by a successful grower The yield of this variety may be greatly increased by pinching out the first or king blossoms which appear. These king blossoms produce the largest peppers. However, in doing so, they reduce the yield. The flesh runs $1 / 2$ to $3 / 4$ inch thick, and is exceptionally mild and pleasant in flavor. Fifteen fruits to a bushel. Pkt., 10c; oz., 35c; 2 ozs., 65c; $1 / 4$ lb., $\$ 1.15$; lb., $\$ 4.50$.

Vaughan's Improved Sweet Mountain. It is a strong ductive. The peppers when young are of a bright green color, without any shade of purple; when ripe they are of a very beautiful red; the flesh is thick, sweet and mild. They often grow 6 inches long by 4 inches through. Our strain has been selected with great care for over twenty years. $1 / 2$ oz., $15 c$; oz., 25c; $1 / 4$ lb., 75c; lb., $\$ 2.50$.

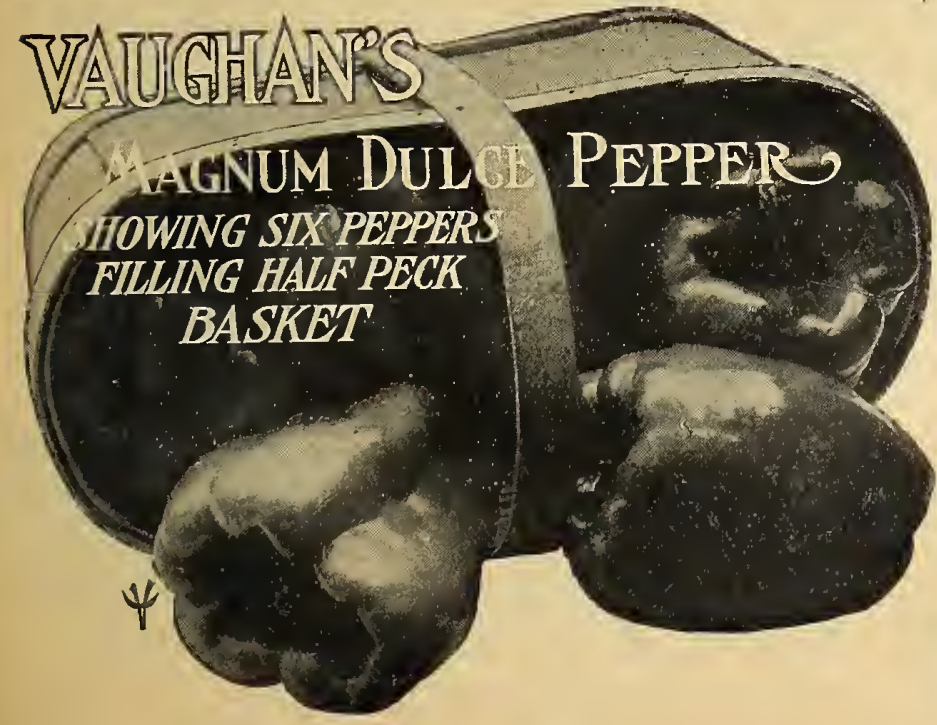

Ruby King: Grows $41 / 2$ to 6 inches long, by $31 / 2$ to 4 inches thick. The The mat or walls, is quite crisp and tender. $1 / 2$ oz., 15c; oz., 25c; $1 / 4 \mathrm{lb}$., 75c; lb., $\$ 2.50$.

Chinese Giant. Double the size of "Ruby King." Not only is it early size will cause it to sell most readily. The fruits are of thick blocky form and of glossy scarlet. They grow four or five inches broad at the top, and are of equal length. All uniformly large. The flesh is mild and unusually thick; it makes an excellent salad sliced and sert
$35 c$; $1 / 4$ lb., $\$ 1.15 ; 1 b ., \$ 4.50$.

Pepper, New Neapolitan. A great market gardeners' variety, two King. It is of good size, mild flavor, and weeks earlier than Bull Nose or Ruby Its great value lies in its prolificacy. The flesh of the fruit is quite thick, and ripens an even bright red. Price, $1 / 2$ oz., 15c; oz., 25c; 1/4 lb., 75c; 1b., $\$ 2.50$. Pepper, New Upright Sweet Salad. This pepper grows updo other sorts. It is a cross between Chinese Giant and a very mild, sweet variety. Its value to the market gardener is in its earliness and mild flavor, so mild, in fact. that even the seeds may be eaten raw without inconvenience. Fruits are of medium size and are produced in good numbers. The color is a very handsome green, and turns a waxen red when ripe. A fine variety for fancy trade. Pkt., 10c; $1 / 2$ oz., 25c; oz., 40c; $1 / 4$ lb., $\$ 1.00 ;$ lb., $\$ 4.00$

Large Bell or Bull Nose.

Cayenne Long Red.

Cayenne Pickling.

Celestial

Elephant's Trunk.

Golden Dawn.

Mammoth Golden Queen

Neapolitan Improved Upright (New)

Red Cherry.

Spanish Monstrous.

Tabasco, Pkt., 10c.

\begin{tabular}{|c|c|c|c|}
\hline $\begin{array}{l}1 / 2 \mathrm{oz} . \\
\$ 0.15\end{array}$ & $\begin{array}{c}\mathrm{Oz.} \\
\$ 0.25\end{array}$ & $\begin{array}{r}1 / 4 \mathrm{Lb} \text {. } \\
\$ 0.75\end{array}$ & $\begin{array}{l}\text { Lb. } \\
\$ 2.50\end{array}$ \\
\hline & .20 & .60 & \\
\hline .15 & .25 & .70 & \\
\hline .12 & .20 & 60 & $\begin{array}{l}2.25 \\
2.25\end{array}$ \\
\hline 12 & .20 & .60 & 2.25 \\
\hline .12 & .20 & :u & 2.2 \\
\hline .20 & .30 & 1.00 & 3.50 \\
\hline .1 & .25 & .75 & $\cdots$ \\
\hline 1 & .20 & & \\
\hline & .2 & .6 & 2.25 \\
\hline & .3 & & \\
\hline
\end{tabular}

\section{P U M P K I N}

\section{VAUGHAN'S SUGAR PIE PUMPKIN}

Flesh very thick, sweet and fine flavored. Makes delicious pies. Price: Oz., 10c; 1/4 lb., 20c; lb., 60c; 5 lbs., $\$ 2.50$.

Winter Queen (Winter Luxury.) Fine quality....

Calhoun. Skin, cream color; flesh, salmon yellow

Large Field. For cattle feeding. $10 \mathrm{lb} ., \$ 2.50 \ldots$

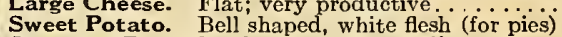

Japanese Pie. Good keeper, fine quality .............

Vaughan's Mammoth Prize. Very productive.

Small Sugar. Good for the Home Garden.

Golden Oblong. Flesh yellow, excellent flavor.

Large Tours, or Mammoth French. Very large size.

Quaker Pie....

\section{RHUBARB}

\begin{tabular}{|c|c|c|}
\hline $\begin{array}{r}\mathrm{Oz} .10 \\
\$ \$ \$ 0.10\end{array}$ & $1 / 4$ L L & Lb. \\
\hline .10 & $\begin{array}{r}\$ 0.20 \\
.20\end{array}$ & $\$ 0.75$ \\
\hline .10 & .15 & .35 \\
\hline .10 & .20 & .50 \\
\hline .10 & .25 & .90 \\
\hline .10 & .25 & .85 \\
\hline .15 & .40 & 1.50 \\
\hline .10 & .20 & .75 \\
\hline .10 & .20 & .75 \\
\hline .10 & .25 & .85 \\
\hline .10 & & .85 \\
\hline
\end{tabular}

Chicago Giant. The best bred and finest variety of Rhubarb to date. MAMMOTH. Oz., 10c; 1/4 lb., 30c; lb., $\$ 1.00$.

Linnaeus. Oz., 10c; $1 / 4 \mathrm{lb}$., 30c; lb., $\$ 1.00$.

RHUBARB ROOTS. Clumps. Each 15c, 25c and 50c, according to size Seedlings, per $100, \$ 4.00$.

RAMPION. Roots and leaves used for Salads. Oz., 25c; 1/4 lb., 80c. SORREL.
Broad leaved French. Cultivated for its leaves. Used like
Spinach. Oz., 15c; $1 / 4$ lb., 50c; lb., $\$ 1.60$.

SAGE. For seasoning. Oz., 15c; $1 / 4 \mathrm{lb}$., 45c; lb., $\$ 1.50$. 


\section{\begin{tabular}{|l|l}
\hline Vaughan's Seed Potatoes & GROWN IN THE \\
\hline
\end{tabular} FAR NORTH}

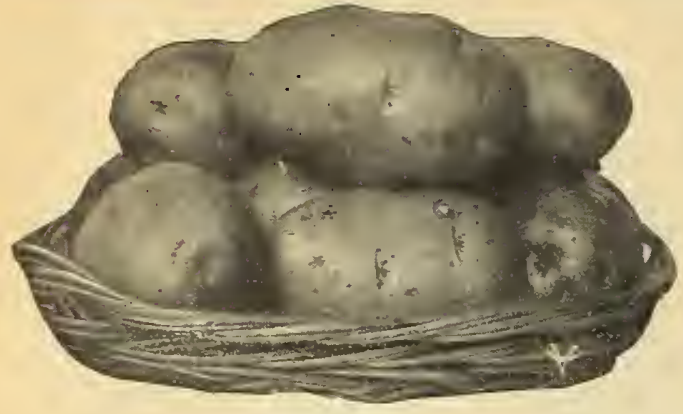

EARLY OHIO

THE last few seasons have been unfavorable for Ohio Potatoes in some localities, so a 1 demand has developed for an early sort that will give a good yield before the later ones are ready. While we have nothing to supplant the Early Ohio, we do offer three in the Second Early Class that are quite as prolific and in some seasons mature only a few days later than the former. They are the Irish Cobbler, Dearborn and Woodbury's White Rose, maturing within a few days of each other in the order named.

For almost twenty years we have grown our Early Seed Potatoes in the Red River Valley of the North. Now Vaughan's Red River Valley-Grown, True-to-Type Early Seed Potatoes are the standard of quality throughout the country. Red River Valley Early Seed Potatoes we have found by careful trials are earlier, more vigorous and better yielders than stock from any other section. Write for latest market prices in quantity lots. 10 bushel price subject to market changes.

The prices on our potatoes are f. o. b. Chicago. If to be shipped from New York, add 50c per sack and 20c per bushel; peck and half-peck prices are the same.

\section{Vaughan's Improved Early Ohio}

Vaughan's Red River Ohios are now the Standard of quality for this sort. We were the first to grow this variety in the Red River Valley many years ago and our stock is the best obtainable. Vaughan's Improved Early Ohio is the earliest heavy yielding quality potato on the market to-day. Peck, 60c; bu., $\$ 1.75$; sack (165 lbs.) $\$ 4.50$; bbl., $\$ 4.70 ; 10$ bu., $\$ 15.00$.

\section{Vaughan's Dearborn}

A grand second early. We think it the finest sort since Irish Cobbler. It matures only a few days later than Cobbler and yields from fifteen to twenty-five per cent better in our trials, it ripens in plenty of time for the high early market. The tubers are round slightly flattened sometimes with a densely netted skin. This sort has a future. $1 / 2$ pk., 40c; pk., 70c; $1 / 2$ bu., $\$ 1.10$; bu., $\$ 2.00$; sack (165 lbs.) $\$ 5.25$; bbl., $\$ 5.45 ; 10$ bu., $\$ 17.50$.

\section{Woodbury's White Rose}

A heavy cropping second early White Potato. It inherits its earliness from its parent Early Rose yet in yield it compares with any of the late sorts like Rural New Yorker or Carman. The tubers are white, not so long as Early Rose and therefore are much more attractive for the ordinary market. In season White Rose ripens about ten days later than Ohio, and in quality it is superior to any other early variety. Especially good on light soil and for a local market. $1 / 2$ peck, 40c; peck, 70c; $1 / 2$ bu., $\$ 1.00$; bu., $\$ 1.85$; sack (165 lbs.) $\$ 4.80$; bbl., $\$ 5.00 \cdot 10$ bu., $\$ 17.00$.

\section{Standard Kinds}

Vaughan's White Ohio. Heavier yielding than the Red Ohio, but white Carman No. 3. A popular main crop variety. Our stock is fine this Rural New Yorker No. 2. Standard White Market Potato. Known Acme. A profitable early potato. Belongs to Ohio type; however, better

Sir Walter Raleigh. The best of the Garman Group. A late, flat than Rural New Yorker.

Vermont Gold Coin. A very profitable crop in loose or muck soils. As soils. The tubers are white, oblong, broad and blocky.

$$
\text { Variety. }
$$

Rural New Yorker No. 2

Carman No. 3

Acme

Sir Waiter Raleigh

Bliss' Triumph

Vaughan's White Ohio

Vermont Gold Coin

11-peck bbl., 25c extra.

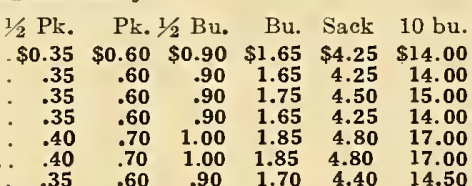

\section{SWEET POTATOES}

GROWN ESPECIALLY FOR SEED

We can offer Yellow Jersey (the most popular Northern sort), Red Jersey, Red Bermuda, Early Carolina and Nansemond.

Yellows

Reds.

3 bbl. lots, 25 per bbl. less

\section{Irish Cobbler}

This variety has attained great popularity in the past few years on account of its extreme earliness and heavy yields. On favorable soils (this variety prefers light or sandy conditions) Irish Cobbler will yield well up in comparison to late varieties. The quality is rather coarse but the appearance is excellent and it meets with a ready sale. We are able to offer Red River Grown stock this year and we know our customers will like it much better than any stock they have seen of the variety heretofore. $1 / 2$ peck, 35c; peck, 60c; bu., $\$ 1.75$ sack (165 lbs.) $\$ 4.50$; bbl., $\$ 4.70 ; 10$ bu., $\$ 15.00$.

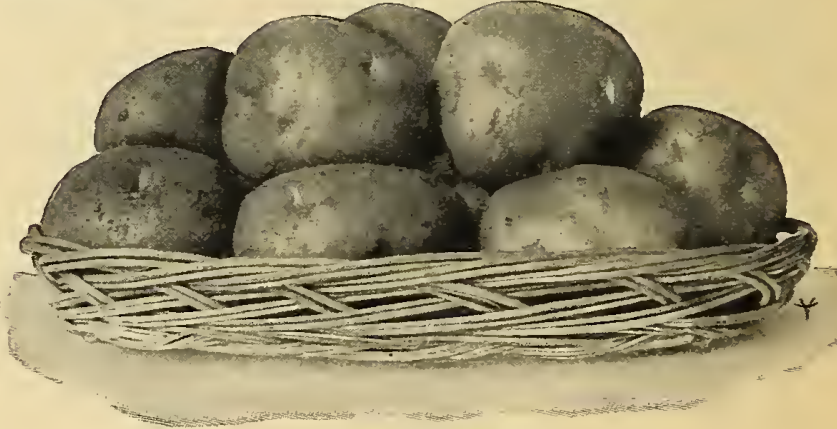

IRISH COBBLER

Russet Rural. (Petoskey.) The new standard late potato. In the past Fichiman thiscons the years it has become the most popular variety in the large a russet or netted skin quality uneta potato districts. Its shape is like a Rural with or Carman, quite late in season. Price, $1 / 2$ pk., $35 \mathrm{c}$; peck, $60 \mathrm{c}$; $1 / 2 \mathrm{bu}$., $90 \mathrm{c}$; bu., $\$ 1.70$; sack (165 lbs.) \$4.40; bbl., \$4.60; 10 bu., \$14.50.

Green Mountain. We think this the most desirable of the late cylindrical Green Mountain. shaped potatoes. Especially good on light and muck soils. Habit of growth and blossoms very distinct from Rural types. Excellent (165 lbs.) \$4.40; bbl., $\$ 4.60 ; 10$ bu., $\$ 14.50$.

\section{NEBRASKA, New Late White}

This is one of the best main crop White Potatoes ever introduced everywhere outyielding the standard main crop kinds. The vines are wonderful growers and very hardy. Does well on heavy lands as the tubers are flat and set near the surface. Price $1 / 2$ peck, $35 \mathrm{c}$; peck, 60 c; bu., $\$ 1.70$; sack (165 lbs.) $\$ 4.40$; bbl., $\$ 4.60 ; 10$ bu., $\$ 14.50$.

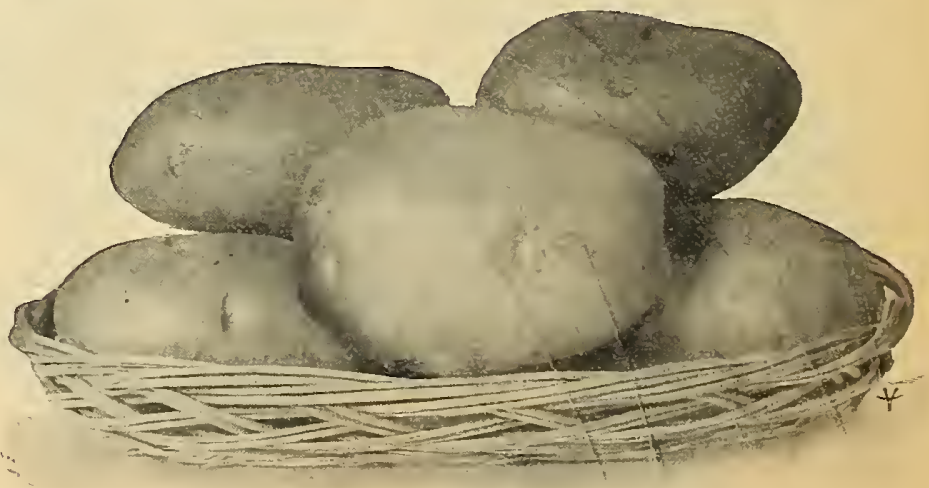

NEBRASKA, NEW LATE WHITE

VAUGHAN'S PEDIGREE SEED CORN-Our list of both early and late varieties is complete and up-to-date. Standard sorts recognized by the different breeding associations. No old varieties with new high-sounding names. Page 22. 


\section{BEST TYPES \\ VAUGHAN'S RADISH}

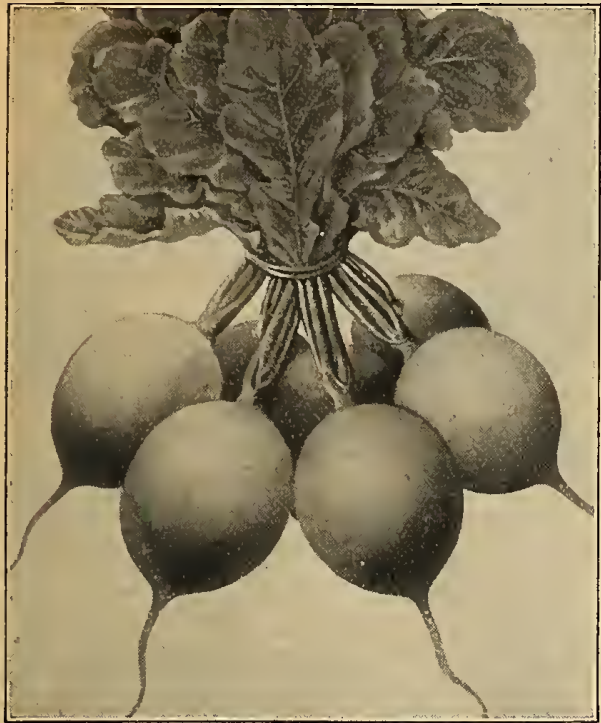

VAUGHAN'S SELECT SCARLET GLOBE

EARLY VARIETIES

\section{IMPROVED EARLY SCARLET GLOBE Vaughan's Selected Stock}

For greenhouse and hotbed forcing, and also for outdoors this is a most desirable sort.

Very early, mild, crisp, juicy and tender; top small and will stand heat and not become pithy.

Its bright scarlet color and handsome shape make it most attractive and one of the best sellers.

Our stock is selected with greatest care, as to size, shape, color and earliness, it is the very best; it is the right one in every respect and a money maker for market gardeners. Oz. 10c, $1 / 41 b .25 c$, lb. 70 c, 5 lbs. $\$ 3.25,10$ lbs. $\$ 6.00$.

Scarlet Globe, Ordinary. Oz. 5c, $1 / 4$ lb. 20c, lb. 50c, 5 lbs. $\$ 2.25,10$ lbs. $\$ 4.00$.

\section{C I C L E}

The finest of the White Radish variety; has long slender pure white roots, crisp to the bite, and remain so until they grow larger. The tops are short, permitting close planting; early maturing, mild. The roots keep a long time before getting pithy.

Many of our customers consider it the finest quality radish they have ever planted.

Owing to its exceptional qualities as a perfect Radish for eating, being mild, crisp, white, it is a great favorite, and a profitable sort for the market gardener with a private trade. $1 / 4 \mathrm{lb} .15 \mathrm{c}, \mathbf{l b} .50 \mathrm{c}$, 5 lbs. $\$ 2.25$.

\section{STANDARD TURNIP SORTS}

\begin{tabular}{|c|c|c|c|c|}
\hline Vaughan's Early Scarlet Globe, White Tip... & $\begin{array}{c}\mathrm{Oz} \\
50.10\end{array}$ & $\begin{array}{l}1 / 4 \mathrm{lb} \text {. } \\
\$ 0.25\end{array}$ & $\begin{array}{r}\text { Lb. } \\
\$ 0.70\end{array}$ & $\begin{array}{r}5 \mathrm{lbs} \\
\$ 3.25\end{array}$ \\
\hline Earliest Carmine Turnip........ & .10 & .25 & .70 & 3.25 \\
\hline Crimson Giant Forcing.. & .10 & .25 & .70 & 3.25 \\
\hline Earliest White Turnip (White Box) ........ & .10 & .25 & .70 & 3.2 \\
\hline Triumph (Variegated).. & .10 & .25 & .70 & 3.25 \\
\hline All Seasons........... & .05 & .15 & .60 & 2.7 \\
\hline Non Plus Ultra......... & .10 & .25 & .70 & 3.2 \\
\hline Early Deep Scarlet Turnip........ & .05 & .20 & .60 & 2.7 \\
\hline Yellow Turnip........... & .05 & .20 & .60 & 2.7 \\
\hline Golden Yellow Summer Turnip & .05 & .20 & .60 & 2.7 \\
\hline aughan's Cardinal Forcing.... & .10 & .25 & .75 & \\
\hline
\end{tabular}

For Garden and Greenhouse Tools, Market Gardeners' Supplies, Fertilizers, etc., see pages 23 to 26 . We carry only high grade, dependable stock.

\section{EARLY VARIETIES SCARLET TURNIP WHITE TIP Vaughan's Sparkler Strain}

This is the most popular Radish for outdoor planting. It combines those qualities of attractive appearance, both color and shape which make it a splendid seller:

It is bright scarlet with white tip, just enough white to give sharp contrast to the red.

The tap root is very slender. We sell many thousands of pounds of this Radish annually to the most critical market gardeners, proving our stock is the very best.

Our seed is most carefully grown from transplanted roots, just right in color, size and shape. Oz. 10c, $1 / 4$ lb. $15 \mathrm{c}, \mathrm{lb} .45 \mathrm{c}, 100 \mathrm{lbs}$. $\$ 40.00$.

Scarlet Turnip White Tip, choice stock. Oz. 5c, 1/4 lb. 15c, lb. 40c, 100 lbs. $\$ 35.00$.

\section{EXTRA EARLY OLIVE SHAPED RADISHES}

\begin{tabular}{|c|c|c|c|}
\hline $\begin{array}{l}\text { Vaughan's } 20-D a y \text { Forcing } \\
\text { Improved French Breakfast } \\
\text { French Breakfast } \ldots \ldots \ldots \ldots \\
\text { Earliest White Olive } \ldots \ldots \ldots \\
\text { Olive Yellow May } \ldots \ldots \\
\text { Oval Deep Scarlet } \ldots \ldots \\
\text { Vaughan's Olive Crystal } \ldots\end{array}$ & $\begin{array}{r}\mathrm{Oz} \\
. \$ 0.10 \\
.10 \\
.05 \\
.10 \\
.05 \\
.10 \\
.10\end{array}$ & $\begin{array}{r}1 / 4 \mathrm{lb} . \\
\$ 0.25 \\
.25 \\
.20 \\
.25 \\
.20 \\
.25 \\
.25\end{array}$ & $\begin{array}{r}\text { Lb. } \\
\$ 0.70 \\
.70 \\
.60 \\
.80 \\
.60 \\
.70 \\
.80\end{array}$ \\
\hline
\end{tabular}

\section{EARLY LONG RADISHES}

ICICLE. The best early white Radish, the

very highest quality and the roots keep a

long time without becoming pithy...... \$ $\$ 0.05$

Brightest Long Scarlet (Cardinal)

Early Long Scarlet (Short Top)

Cincinnati Market

Vaughan's Market (Long White)
Wood's Early Frame

Half Long Deep Scarlet.

.05
.05
.05
.05
.05

$\$ 0.15$

.15

$.05 \quad .15$

$\begin{array}{ll}.05 & .15 \\ 05 & .20\end{array}$

$\begin{array}{ll}.05 & .20 \\ .05 & .20\end{array}$

\section{SUMMER VARIETIES}

\begin{tabular}{|c|c|c|c|}
\hline $\begin{array}{l}\text { Improved Chartier. } \\
\text { Long White Vienna. } \\
\text { White Strassburg... } \\
\text { White Stuttgart.... }\end{array}$ & $\begin{array}{r}\mathrm{Oz} \\
\$ 0.05 \\
.05 \\
.05 \\
.05\end{array}$ & $\begin{array}{r}1 / 41 \mathrm{~b} \\
\$ 0.20 \\
.20 \\
.15 \\
.20\end{array}$ & $\begin{array}{r}\text { Lb. } \\
\$ 0.60 \\
.60 \\
.50 \\
.60\end{array}$ \\
\hline
\end{tabular}

White Stuttgart...

WINTER RADISHES

Do not sow until last of June

Chinese Mammoth, or Celestial ....

Rose, or Scarlet China Winter

Round Black Spanish

Long Black Spanish

Half Long Bldck Winte

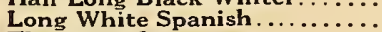

The Munich . ................

$\begin{array}{rr}\text { Oz. } & 1 / 4 \mathrm{lb} \\ \$ 0.05 & \$ 0.20 \\ .10 & .25 \\ .05 & .20 \\ .10 & .25 \\ .10 & .25 \\ .10 & .25 \\ .10 & .25 \\ .10 & .25\end{array}$

Lb.

$0.60 \$ 2$.

$.60 \quad 2.75$

$70 \quad 3.25$

$\begin{array}{rr}.70 & 3.25 \\ 75 & 3.50\end{array}$

$70 \quad 3.25$

$.70 \quad 3.25$ 


\section{SALSIFY OR OYSTER PLANT}

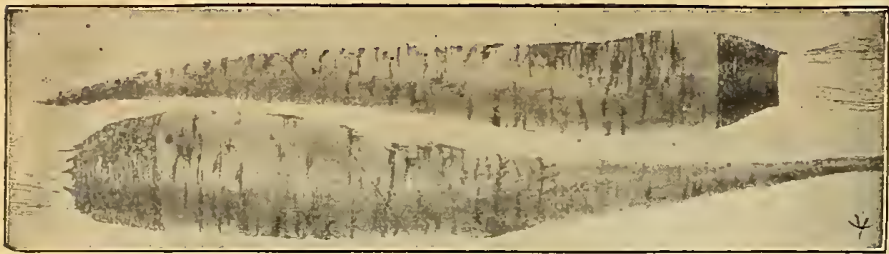

Sandwich Island Mammoth. Grows uniformly to an fully double the size and weight of the roots of the old variety. The roots, notwithstanding their size, are of superior quality and very delicate flavor. Oz., 20c; 1/1/ lb., 50c; lb., \$2.00.

LONG WHITE SALSIFY. Oz., 20c; $1 / 4 \mathrm{lb} ., 50 c ; 1 b ., \$ 2.00$. Scorzonera. (BLACK SALSIFY). Oz., 15c; $1 / 4 \mathrm{lb} ., 40 \mathrm{c}$.

\section{SP I NACH}

Giant Fill Basket. (New). Considered in

best Spinach ever produced. Our customers and trial grounds report phenomenal results. Its broad thick leaves are produced in remarkable abundance.

Price, lb., 30c; 10 lbs., $\$ 2.75$.

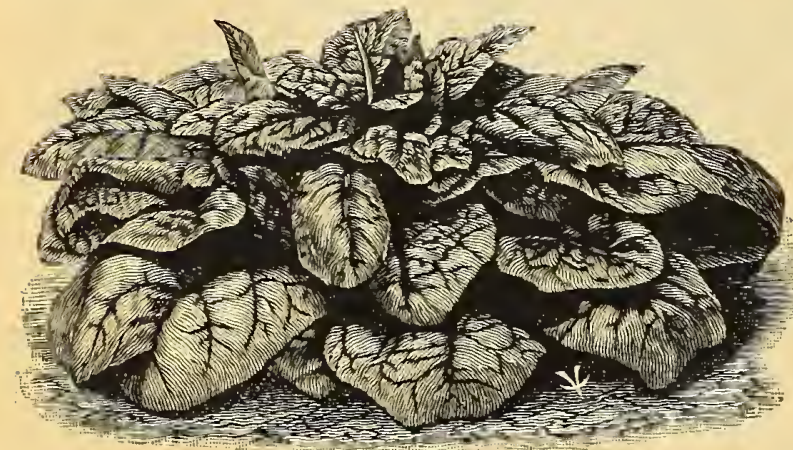

For spring planting-Norfolk Savoy or Bloomsdale, Large Round Leaf and Victoria are most generally planted.

The new variety Vaughan's Fill Basket, however, produces much larger plants in the same time and Vaughan's Triumph does not run to seed as quickly as other kinds.

For Fall Season-Norfolk Savoy, Large Round Leaf and Prickly or Winter are good sorts.

Vaughan's Giant Fill Basket. As early as any and produces the largest plants of allspinach. Oz., 5c; $1 / 4$ lb. 10c;lb., 30c; 10 lbs. \$2.75.

\section{VAUGHAN'S NORFOLK SAVOY SPINACH}

The popular Southern Spinach. The leaves remarkably thick and blistered, extremely hardy. Do not settle in the barrel in shipping as do other varieties. Our strain is right. Very early. $1 / 4$ lb. 10c., lb., 25c; 10 lbs., \$2.25.

Extra Large Round Leaved-The most popular western variety much planted around Chicago. $1 / 4$ lb., 10c; lb., 25c; 10 lbs., $\$ 2.25$.

Vaughan's Triumph (new)-This variety will stand summer heat without running to seed longer than any other sort. $1 / 4 \mathbf{l b}$., 10 c; lb., 25c; 10 lbs., $\$ 2.25$.

Bloomsdale-Same as Norfolk Savoy. Lb., 25c; 10 lbs., \$2.25.

Large Round Viroflay-Early and large. Lb., 25c; 10 lbs., \$2.25.

Victoria-large and long seasoned thick leaves. $1 / 4 \mathrm{lb}, 10 \mathrm{c}$;

lb., 25c; 10 lbs., $\$ 2.25$.

Long Standing-Smooth seed. Slow to run to seed. $1 / 4$ lb., $10 \mathrm{c} ; \mathrm{lb} ., 25 \mathrm{c} ; 10$ lbs., $\$ 2.25$.

Prickly Seeded-Hardy for late planting. Lb., 25c; 10 lbs., \$2.25.

New Zealand-A particular branching type for summer use.

Price, oz., 7c; $1 / 4$ lb., 20c; lb., 60c.

\section{SWISS CHARD--A Money Crop}

Cut and Come Again Spinach, as it is sometimes called, is far superior to the common Beet for greens and equal to Spinach. Planted like Beets, it may be cut throughout the entire summer and fall when no spinach is to be had. Often used as a catch crop chard gives quick results where ground would otherwise stand idle. Especially popular with the Italian gardeners.

Large Leaved or Sea Kale Chard. Oz., 7c; $1 / 4$ lb., 25c; lb., 75c;

Lucullus-A very curled sort, very large leaves, broad mid-ribs Price, oz.. 10c; $1 / 4$ lb., 30c; lb., $\$ 1.00$.

Lyon-A new variety especially selected for its broad mid-ribs and stems which are cooked like asparagus. Oz.,10c; $1 / 4$ lb., 30c; lb., $\$ 1.00$.
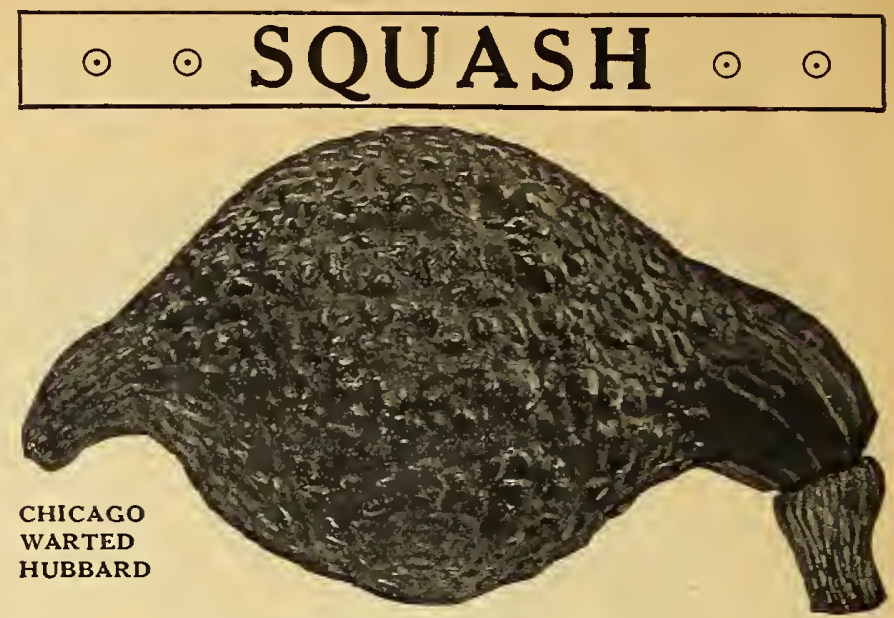

\section{SUMMER VAKIETIES}

aughan's Giant Summer Crookneck. The best of the Yellow Summer ookneck varieties. A large and fine strain. Oz., 10c; 1/4 lb., 25c; lb., 80c. Mammoth White Bush. (Patty Pan.) An improved selection of the ant White Summer Crookneck. A white selection $\mathrm{Oz}$. 1/4 lb. Lb. f Yellow Summer Crookneck ..............\$0.10 $\$ 0.25 \quad \$ 0.80$ ellow Summer Crockneck. Smaller than Giant. ... $\quad .10 \quad .25 \quad .80$

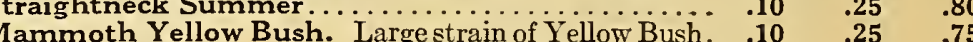
White Bush. (White Patty Pan) .............. $\begin{array}{ll}.30 & .90 \\ .25 & .75\end{array}$ $.30 \quad 1.00$

\section{WINTER VARIETIES}

Chicago Warted Hubbard. A selection of the largest, heaviest dark rough skinned specimens of the old Hubbard. We are and have been headquarters for years. Price, oz., 10c; 2 oz., 15c; $1 / 4$ lb., 25c; lb., 80c; 5 lbs., $\$ 3.75 ; 10$ lbs., $\$ 7.00$.

Hubbard. An extra choice strain, none better. Oz., 10c; $1 / 4$ lb., 25c; lb., 80c; 5 lbs., $\$ 3.75 ; 10$ lbs., $\$ 6.00$.

Golden Hubbard. A form of Hubbard. Almost bug-proof

Price, oz., 10c; $1 / 4$ lb., 30c; lb., 90c.

Delicious. The quality squash..........\$0.10 $\$ 0.30 \quad \$ 1.00$

Boston Marrow. Fall orange sort......... $.08 \quad \begin{array}{llll}.20 & .75\end{array}$

Chicago Orange Marrow. Large as Hub-

$\begin{array}{lll}10 & .25 & .75\end{array}$

Pike's Peak. Large oval fruits............

Faxon's Brazilian. Long keeping............. $.10 \quad .25 \quad .75$

Golden Bronze. Very sweet.................

$\begin{array}{llll}\text { Essex Hybrid. (Turk's Cap.) Large fall sort. } & .10 & .25 & .75\end{array}$

$\begin{array}{lllll}\text { Marblehead. Fine quality, blue, olive shape. } & .10 & .30 & .90\end{array}$

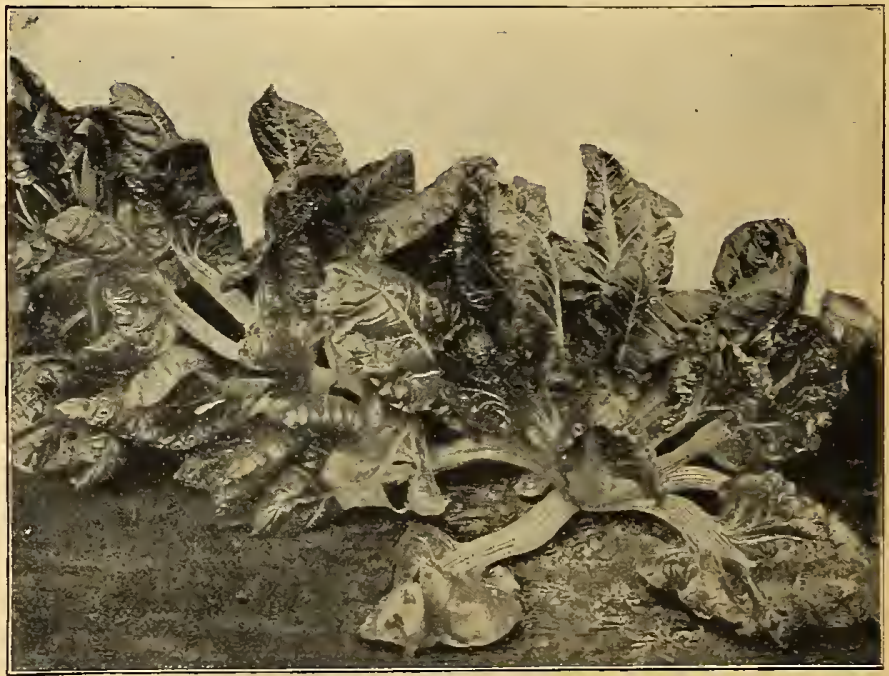

SWISS CHARD-Nothing better for "Summer Greens" 


\section{VAUGHAN'S TOMATO SEED}

Our seed is raised by the most experienced growers, some of whom specialize on par-

is very dear for the market gardener.

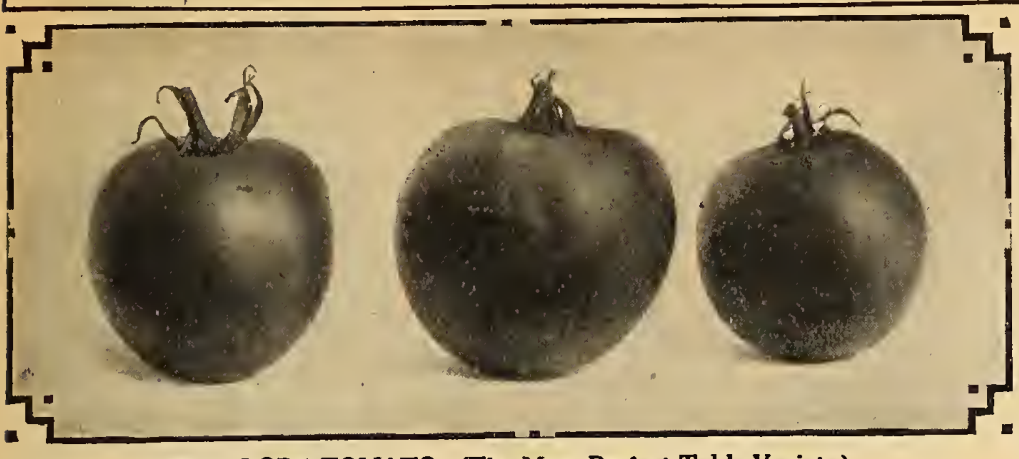

NEW GLOBE TOMATO (The Most Perfect Table Variety)

Certain Tomatoes sell much better on some markets than do other sorts. For example, a red tomato sells well in New York while a purple sort is wanted in Chicago. Find out what your customers want.

New Globe. An entirely new shaped purple tomato. The majority of Nruits being elongated in shape. Medium in season it is exceedingly prolific and bears large sized fruit throughout the season. In quality purple sort. Every gardener raising tomatoes should have a planting of this new kind. $1 / 2$ oz., 12c; oz., 20c; $1 / 4$ lb., 70c; lb., $\$ 2.50$.

June Pink. The earliest pink tomato. We have a fine strain Our last few seasons $1 / 2$ oz., 12c; oz., 20c; $1 / 41$ lb., 70c; lb., $\$ 2.50$.

Early Detroit. (New) See page 4-novelties. A new second early purple variety. Summarized, it is an early Beauty producing even more marketable fruits than that old standard.

$1 / 2$ oz., 12c; oz., 20c; $1 / 4$ lb., 70c; lb., $\$ 2.50$.

Vaughan's Select Earliana. The earliest large smooth red Tomato variety is without equal as an early. Our strain has been most carefully bred early in season and produces a large percentage of smooth fruit.

$1 / 2$ oz., 12c; oz., 20c; $1 / 4$ lb., 60c; lb., $\$ 2.00$.

Bonny Best. An improved type of Chalk's Early Jewel Tomato. A red variety ripening right after Earliana and producing a fine large smooth fruit. It bears for a much longer period than Earliana, lasting well into the main crop season. $1 / 2$ oz., 12c; oz., 20c; $1 / 41$ b., 70c; lb., $\$ 2.50$.

\section{POPULAR STANDARD}

Per pkt., 5 cents for any of the following except when noted:

ACME. Early, large, smooth pinkish, purple in color, always $1 / 2 \mathrm{Oz} .1 \mathrm{Oz} .1 / 4 \mathrm{lb}$.

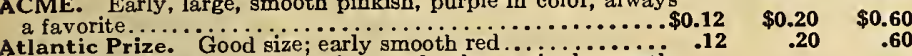

BEAUTY. Fine strain of this popular large sized smooth

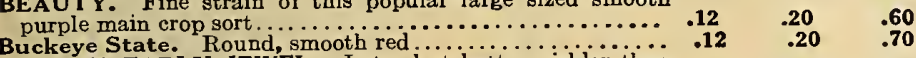

CHALK'S EARLY JEWEL. Later but better yielder than

CHALK'S EARLY JEWEL. Later but better yielder than $\mathbf{. 1 2}$

$.20 \quad .60$

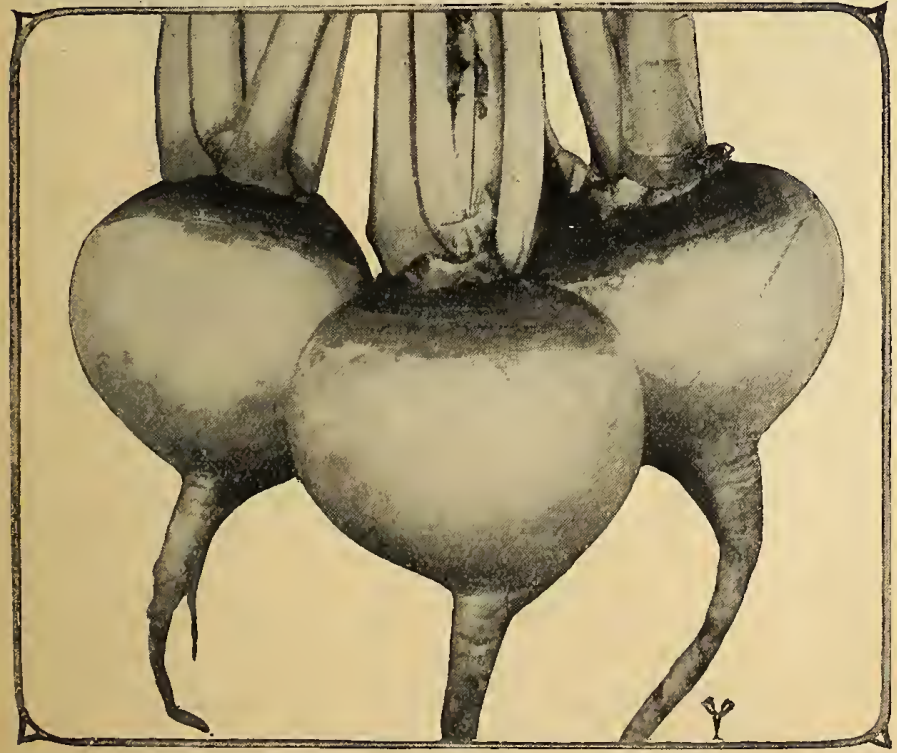

PURPLE TOP WHITE GLOBE TURNIP

\section{POPULAR STANDARD_-Continued}

CORELESS. A late crop. Round sort

wonderfully prolific and of fine

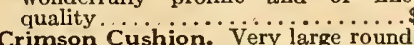

Crimson

$\begin{array}{lllll}\text { Cream City. Purple, large and early. } & .12 & .20 & .60 & 2.00\end{array}$

DWARF CHAMPION. The mo....

popular dwarf. Purple in color, al-

smooth.

DWARF STONE. 'Red, the largest

dwarf. .

Earliest of All-Vaughan's. The

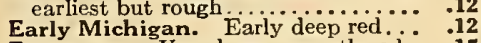

Enormous. Very large, smooth red.:

Favorite. Early, large smooth red..

Freedom. Very early bright scarlet..

Golden Queen. Rich deep yellow...

Imperial. Large smooth purple .....

Honor Bright. A fine shipper, largo

HUMd good quality ..................

tomato. Early bright scarle.......

MAGNUS. Large potato-leaved purple

MATCHLESS. A fine large bright red

Model-Vaughan's. One of the best

Perfection. One of the best scarlets:

PONDEROSA. The largest of all STONE IMPROVED. The best main crop. The most productive of all crop. The most productive of all varieties and a tine shipper.

strain unsurpassed..................
Tall Champion. A wonderf of medium sized purple Acme colored

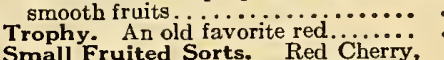

Small Fruited Sorts. Red Cherry,

Red Currant, Yellow and Red Pear,

Red Plum, any one.....................
Forcing Sorts. Comet, Sunrise, Sterling Castle, Hubert's Marvel, Lister's Prolific, Frogmore Select, each, pkt., 25c; 1 oz., 50c. Lorillard, Sutton's Best of All, pkt., 10c; oz., 35c.

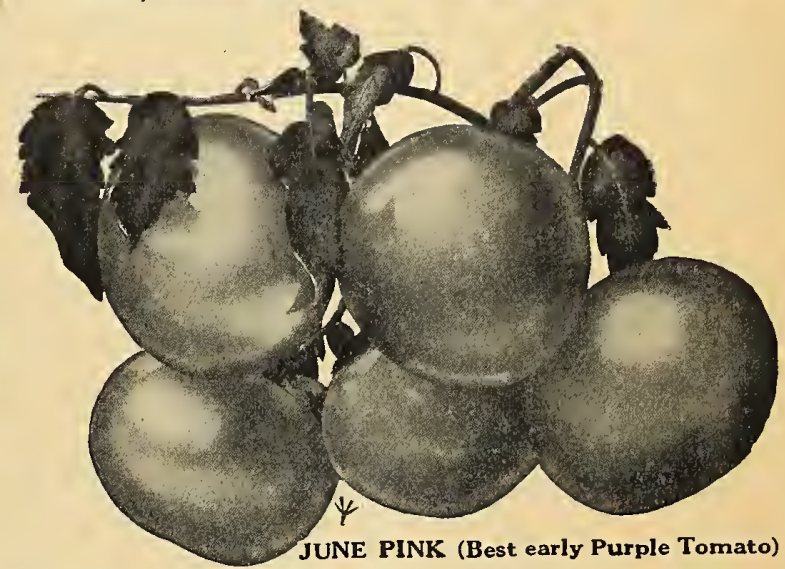

\section{TURNIP}

White Milan. Earliest of all

Early Extra Purple Milan

Purple Top Strap Leaf, $10 \mathrm{lbs}$., $\$ 3.50$

White Egg

Purple Top White Gilobe, 10 ibs., $\$ 4.50$

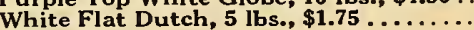

Amber Globe .

Yellow Aberdeen

Golden Ball .

Large Yellow.

Long Cowhorn

Early Snowball ....

Yellow Stone

White Norfolk

Teltow..........

RUTABAGA, OR SWEDE

$\$ 0.10$

$1 / 4 \mathrm{lb}$.

$\$ 0.30$

\begin{tabular}{ll}
.65 & 2.25 \\
.60 & 2.00 \\
.75 & 3.00 \\
.60 & 2.00 \\
.65 & 2.25 \\
.65 & 2.25 \\
.75 & 2.50 \\
.60 & 2.00 \\
.60 & 2.00 \\
.65 & 2.25 \\
.60 & 2.00 \\
.65 & 2.00 \\
.70 & 2.50 \\
.60 & 2.00 \\
\hline 1.10 & 4.00 \\
& \\
\hline 60 & 2.00 \\
\hline
\end{tabular}

Monarch, 10 lbs., $\$ 4.50$

$1 / 4 \mathrm{lb}$.

Laing's Swede

$\$ 0.05$

New Breadstone.

Carter's Imperial Swede

American Improved, 10 lbs., $\$ 4.50$

Skirving's Ru

White Swedetabaga.

Rhode Island Rock

Sutton's Champion

Sweet German

Vassar (New)

Bangholm Danish
.30

.15

.20

.15

.15

.15

.15

.15

.15

.15

.15

$b$.
.90
.90
.40
.45
.50
.40
.50
.45
.45
.50
.50
.45
.45
.50
.45
.75

Lb.

$\$ 0.15$
.15
.15

.15

.15

.15

.15

.20

.15

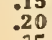




\section{Vaughan's Pedigree Seed Corn}

\section{Our Seed Corns, Early and Late, Dents and Flints, Fit Every Corn Growing Locality}

The 1915 wet season has resulted in many of the northern sections being practically without giving good seed corn this year. We now have (Jan. 1st) limited supplies as below. After March 1st write us for special Corn List.

Seed Corn for the whole country cannot be raised in one locality. Our Seed Corn is grown by the most expert growers in those localities where each variety does its best. Kinds suitable only for a short or medium corn-growing season are raised for us in Northern sections. Main Crop sorts are grown for us in sections where they reach their full maturity and development. Order Seed Corn early, then you can make your own vitality tests before planting. We test bi-monthly and no Seed Corn of doubtful vitality is shipped out by us. Prices subject to change.

\section{EARLY VARIETIES}

Madison Yellow Dent.

in 100 to 105 days of ordinary

Dent, but resembles the latter
closely set together in even rows, variety otherwise. Ears $81 / 2$ in. long, 16 rowed, dark red Cob. The kernels are deep ocalities. Price, shelled from selected ears, $1 / 2 \mathrm{pk} 75 \mathrm{c} ; \mathrm{pk} \$ 1.35 ;$ bu $\$ 4.50 ; 2$ bu or over at $\$ 4.25$ per bu.

We have a few crates, hanger dried, Michigan grown corn at $\$ 5.50$ per bushel crate.

Reid's Yellow Dent, Northern Grown. The highest standard Yellow Dent Corn grown in Illinois, We have never dared sell the regular full sized type of "Reid's" north of Kankakee and La Salle counties; while it really matures best south of that parallel we know some dealers who pick small ears from their crop, grown farther south and sell the same in Northern Illinois. Such are not honest seedsmen. We have secured a selection of Reid's Dent this season which has grown and matured in fire dry condition within 50 miles of Chicago for three years and this we now offer for use in Cook County and westwarú as the finest, highest grade yellow Corn which can be safely planted this far north. Shelled 1/2 pk 75c; pk \$1.25; bu \$4.00. A few crates of selected ears at $\$ \$ .00$ per bushel.

Minnesota No. 13, or Wisconsin No. 8. A heary yielding, extremely Early Yellow Dent Corn. It and this variety furnishes a large amount of fodder. Grows to a height of $8 \mathrm{ft}$. on good soil. Ears, medium size, 8 in. long. 16 row, and taper toward the tip. The kernels show a good Dent type and are of fair depth. It is not as well bred a type yet as Madison Yellow Dent. It is, however, about 10 days earlier. Minnesota grown shelled from selected ears. $1 / 2$ pk $75 \mathrm{c}$; pk $\$ 1.35$; bu $\$ 4.50$.

North Star. This variety which has been featured in our catalog for more than 25 years we have occasionally lost our crop of, but good customers of ours in the vicinity of Baraboo, Wisconsin, have maintained a notable purity of selection and we renewed our planting stock last spring. The resulting crop on our own farms this autumn has proven very early, being dry and fit for seed purposes in September. This Corn will mature as far north as Madison, wisSouthern Minnesota and Middle Wisconsin. A little 1914 seed. Price, Sbelled Corn, 1/2 pk 75c; pk $\$ 1.35 ;$ bu $\$ 4.50 ;$ Selected ears, bu crate $\$ 5.50$.

Pride of the North. A very desirabe variety for southern Wisconsin, Michigan and northern Illinois, especvery early. Type not well fixed. Price: Shelled, pk 85c, \$2.75, bu 2 bu \$5.00.

Silver King, or Wisconsin No. 7. White Dent matures in 100 to 105 days. of good cylindrical shape enough so rapid ripening is not checked. Will ripen as far north as central Wisconsin. Michigan grown seed. Price: shelled, from selected ears, $1 / 2$ pk $75 \mathrm{c}$; pk $\$ 1.35 ;$ bu $\$ 4.50$. Selected ears, per bushel crate, $\$ 5.50$.

Dakota Sunshine. The earlest Dent Corn. Matures in better than 90 days. Kernels are quite dented, yellow Price, Sbelled, $1 / 2$ pk 90c; pk $\$ 1.50$; bu $\$ 5.00$.

\section{MEDIUM AND LATE VARIETIES}

\section{Reid's Yellow Dent.}

(Shelled and on ear.) The great prize-winning Show Corn. Brought to Illinois in 1846 pearance of ears. It is more accurately described as follows: Ear 9 to 10 in. long, 7 in. around, 18 to 24 rows with narrow space between rows; deep grains with small cob, well filled at butt and tip. We offer a very choice selection of seed grown from pedigree seed selections for years. It has won first prizes at Springfield State Fair and Nation $\$ 1.00 ;$ bu $\$ 3.50 ; 4$ bu $\$ 15.00 ; 10$ bu $\$ 30.00$. Selected ears, bu. crate, $\$ 4.50 ;$ three for $\$ 12.75$.

Gold Mine. This is now a standard yellow for central Corn belt. We as to maturity all through central Illinois, Iowa and like sections as far north as Dixon and Cedar Rapids. Price: Pk 75c; bu $\$ 2.504$ bu lots $\$ 9.00$.

Leaming. This Corn is a very popular large Yellow Dent variety. The each stalk. Averages about 20 rows, has a deep kernel with small red cob. It is the feeder s ideal Corn. Ripens in 100 to 110 days of good Corn weather. Price: Pk 75c; bu $\$ 2.50 ; 4$ bu lots $\$ 9.00$.

Silver Mine. (Iowa.) In this we offer one of the best standard White claimed to have produced 215 bushels per acre); it will mature in a fair season as tar north as Dubuque, Iowa. It has shelled 64 pounds of Corn to 6 pounds of cobs. Customers who are looking for a big yield will do well to put in a good acreage of Silver Mine. Price: pk 75c; bu $\$ 2.50 ; 4$ bu lots $\$ 9.00$.

Boone County White. The highest type of White Dent 120 day great prize winner at Corn Shows! Central Illinois Seed of class! Price: selected ears, bu crates $\$ 4.50 ; 3$ bu $\$ 12.75$; shelled, $1 / 2 \mathrm{pk} 60$ c; pk $\$ 1.00$; bu $\$ 3.50$.

See our General Descriptive Catalog for varieties of Grass and Farm Seeds. We offer all the leading sorts of Oats, Wheat,

\section{FLINT VARIETIES}

Longfellow Flint. A beautiful 8-rowed Yellow Flint. Ear from 10 to 75 ; bu $\$ 2.50$. postpaid large pkt $10 \mathrm{c}$, pt $25 \mathrm{c}$, qt $35 \mathrm{c}$.

Giant Long Flint. A tawny and smoky white variety, one of the ing habit and breadth of blade. Price: $1 / 2$ pk 40c; pk 75c; bu $\$ 2.50 ; 2$ bu for $\$ 4.75$. .

Golden Dew=Drop. A handsome, bright rellow, 8-rowed Flint postpaid. Pk 75c; bu $\$ 2.50 ; 2$ bu for $\$ 4.75$. King Philip. (Reddish Flint.) Price: shelled, pkt 10c, pt 25c, qt 35c,

Will's Jehu 70=Day. This is probably the earliest valuable Yellow in Dakota for best Yellow for that climate. Dakota Grown. Price: pkt 10c, postpaid. By express, $1 / 2$ pk 90c; pk $\$ 1.50$; bu $\$ 5.00$.

Rhode Island White Cap Flint. A variety particularly suited pk 85c; bu \$3.00. Postpaid, pkt 10c, pt 25c, qt 35c.

Smut Nose. A popular Wisconsin and Michigan variety usually planted Smen planting time is too late for Dent varieties. Price: sbelled, pk 75c; bu \$2.50. Postpaid, pkt 10c, pt 25c, qt 35c. 


\section{REVISED \\ A B C LIST OF SUPPLIES}

NOTICE-Prices quoted in this Catalogue are subject to change without notice, owing to the unsteady condition of market. This applies partinotice, owing to the unsteady condition of market. This
cularly to Fertilizers. Supplies postpaid only if so stated.

APRONS, Rubber

These are especially made for us of best quality of Black Sheeting, and are $1 \frac{1}{4}$

yards long. Each, $\$ 2.00 ; 3$ for $\$ 5.70$. Postage, 25c each extra.
Waterproof, Oiled, Yellow-Will give good satisfaction, each $\$ 1.00 ; 3$ for $\$ 2.75$.

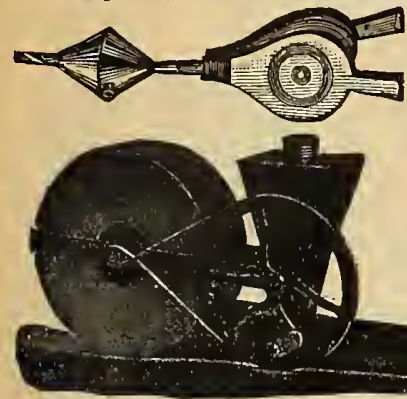

\section{BELLOWS}

American. Used for dusting plants with sulphur or like material. Three sizes, Each, \$1.00, \$1.25 and \$1.35.

PEERLESS SULPHUR BLOWER. The best machine on the market for applying sulphur, paris green, slug shot, etc., to plants in greenhouses. A $200-\mathrm{ft}$. greenhouse can be easily powdered in five JUMBO POWDER GUN, 25c.
CYCLONE, small size, 15 c.

LEGGETT'S

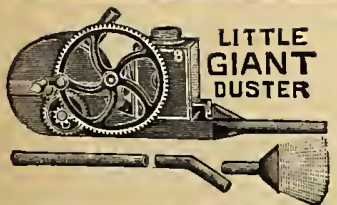

LITTLE GIANT DUSTER

The best dry powder gun; can dust two rows at a time. Each, $\$ 6.00$.

DIBBERS. For transplanting vegetable plants. Steel point; very desirable. Each, 30c; postpaid, 40 c.

CARNATION SUPPORT-Common Sense. The best and simplest Carnation Support on the market to date. Has a 24-inch galvanized stake that will hold 1 to 4 rings. The anchor or foot holds the support erect and firm. The rings are prevented from twisting or sliding by the crimps in the stake. Write for descriptive pamphlet and prices in large quantities. Price, 2-ring supports per $100, \$ 2.00 ; 1000, \$ 17.00$, f. o. b. Chicago. $\$ 2.50$ per $100 ; \$ 20.00$ per $1000 \mathrm{f}$. o. b $\$ 3.00$ per $100 ; \$ 23.00$ per 1000 f. o. b. New York City.

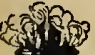

\section{FUMIGATORS}

No. 1. Eureka, galvanized, holds $1 / 2$ peck of stems

No. 2. Eureka, galvanized, holds 1 peck of stems

No. 3. Eureka, galvanized, holds $1 / 2 \mathrm{bu}$. of stems.
No. 4. Eureka, galvanized, holds $3 / 4$ bu. of stems.

EXTRA HEAVY BRAIDED GARDEN LINE

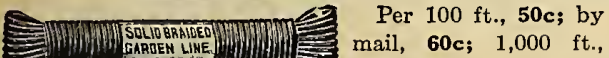
GAREEH LME,

GARDEN LINE REEL, each. $60 c$.

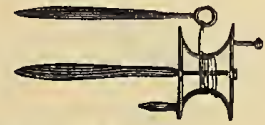

GLAZING TOOLS AND MATERIALS
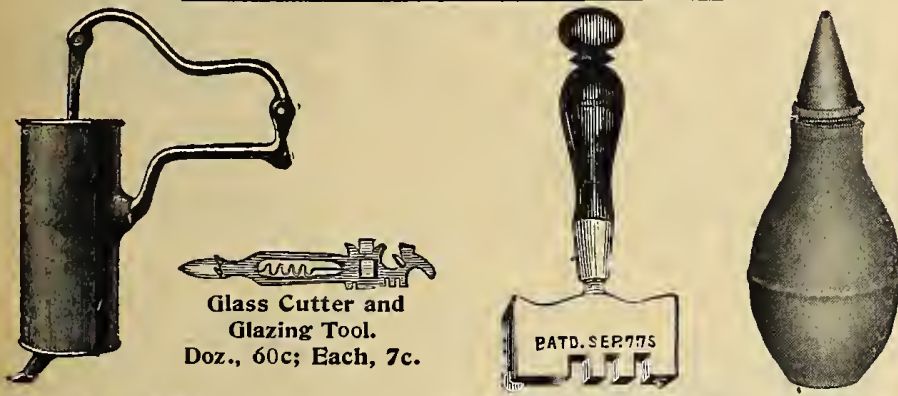

MASTICA MACHINE

DIAMOND GLASS CUTTER PUTTY BULB Both at Chicago and New York we are headquarters for Mastica, jobbing at low rates in quantity.

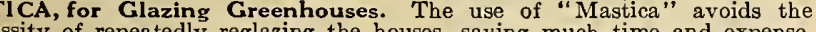
With "I of repeatedly reglazing the houses, saving much time and expense. easily removed can bed in or use outside, with a machine. Broken glass can be easily replaced by new without the breakage of other glass, which feet (one side). Price, per gal., $\$ 1.35 ; 5$ gals., $\$ 6.35 ; 10$ gals., $\$ 12.15 ; 22$ gals.,

MASTICA MACHINE. Each, $\$ 1.35 ; 5$ for $\$ 6.25$.

DIAMOND GLASS CUTTER. With guide wheel, each

GLASS CUTTER AND GLAZING TOOL. Doz., 60c; each .

PUTTY KNIFE, No. 120. A very good tool. Each, 25c; 3 for

$\$ 4.50$

SCOLIY'S PU. Sprinkler with a tube instead of spray for applying liquid putty in glazing greenhouses. Each, $\$ 1.00 ; 3$ for $\$ 2.75$.

GLAZING PUTTY, Twemlow's Old English. By using this putty greenhouses can be glazed in half the time and for less money than if ordinary putty is used. It will take five gallons to glaze a house $100 \times 20$ feet at a cost of $\$ 8.00$. Being semi-liquid, it can be put on with an ordinary putty bulb very quickly, and as it never becomes hard, broken glass can always be removed without any danger to the other lights. Per gal. $\$ 1.65 ; 5$ gals., $\$ 8.00 ; 10$ gals., $\$ 16.00 ; 25$ gals.

\section{VAUGHAN'S PERFECTION GLAZIER POINT'S}

NO RIGHTS OR LEFTS

No. 2. Large single thick glass.

No. 21/2. Double thick for greenhouses and skylights.

No. 2. (Weight $1 \mathrm{lb}$.) Per box of $1000,55 \mathrm{c}$; in lots of 5000 , by express, 50c per 1000.

No. 21/2. (Weight 11/2 lbs.) Per $1000,60 c$; 5000 at 55c.

Pincers or pliers, 50c; postpaid, 60c.

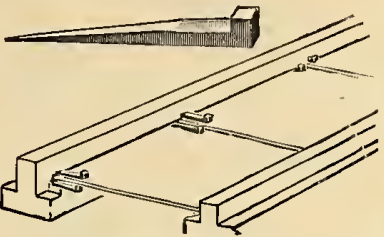

\section{SIEBERT'S IMPROVED GLAZING} POINTS

Easy to drive and made so that they wil not wedge or crack the glass in driving First, it gives a good surface and makes it very easy to drive with a chisel; second, the point is very easily pulled out when repairing greenhouse roof. They are made in two sizes, $5 / 8$ and $7 / 8$ inches long, and are
put up in 1-lb. packages. Price per lb., put up in 1-lb. packages. Price
45 c; 5 lbs., $\$ 2.00 ; 20$ lbs., $\$ 7.50$.

There are over 1500 points in a pound package of $5 / 8$.
There are over 1150 points in a pound package of $7 / 8$

GARDNER'S GLOVES, per pair

$\$ 1.25$

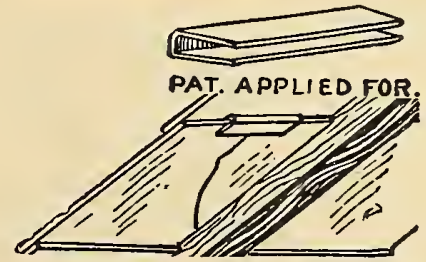

PEERLESS REPAIR CLAMP A simple device for repairing broken greenhouse glass. Easily adjusted from inside of house. Saves labor, coal and glass. If applied as soon as crack is noticed the pane is just as strong as before, and will not sag or drop out.

Price per box of 100 clamps. $\$ \mathbf{\$ 1 . 0 0}$

GRAFTING WAX. Per $1 / 4-\mathrm{lb}$. bar, 12c; $1 / 2-\mathrm{lb}$., bar 20c; 1-lb. bar ...... \$0.35 MOUNT BEACON GREEN, for shading greenhouses. Per gallon, $\$ 1: 65$;

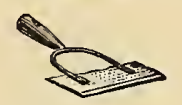

GRASS HOOKS or Sickles. English. Riveted back. Ea.\$0.50 HOE, Warren. Each

HOES. Scuffle. Price, without handle, each 6-inch,

60c; 8-inch, 70c; 10-inch.

\section{RUBBER HOSE, ETC.}

\section{ELECTRIC NON-KINKABLE GUARANTEED HOSE}

A brand of hose manufactured especially for greenis made of best quality rubber, very strong; the jacket of canvas or duck is mixed in such a way with the outer cover that it is extremely pliable and will not kink or crack. Comes in reels of 500 feet; order exact number of feet you require. We can cut in any length. Guarantee-We guarall defects in quality workmanship for the period of one year. This guarantee does not cover improper handling or abuse.

Price $3 / 4$ or $1 / 2$ inch; Couplings Free; Samples Mailed Free if Desired 1 to 24 feet..........19c per ft. $\quad 50$ to 99 feet.......17c per ft. 5 to 49 feet............. $\quad 100$ to 400 feet........ HOSE COUPLER, "The Snap." A new and simple coupling, easy to operate; stationary washer; cannot fall out.
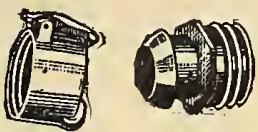

No. 1

No. 2

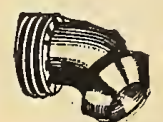

No. 3

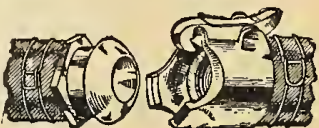

No. 1.-Screws onto hydrant or old threaded coupling; use with No. 2 or No. 4 in connecting hose. Each, 20c; doz., \$2.00.

No. 2. - Screws into faucet or ground pipe on which it may be left permanenttly and to it the hose is attached by the lever connection, No. 1 or No. 5 . Can also be crewed into old threaded coupling. Each, 15c; doz., \$1.60.

No. 3.-Gooseneck; screws in to the old threaded coupling. Most useful at the hydrant. Each, 15c; doz., \$1.35.

No. 4.-Corrugated for insertion directly in the hose. Use with No. 5 for connecting hose. Each, 15c; doz., \$1.25.

No. 5.-Corrugated for insertion in the hose. Use with No. 4 for connecting hose. Each, 25c; doz., $\$ 2.50$.

Common.-For $1 / 2$ or $\frac{3}{4}$-inch hose. Each, 12c; doz., \$1.25. 1-inch, each $16 c$; dox., $\$ 1.65$. 
THE COOPER HOSE MENDER

It is simple, practical and effective. It does not reduce the diameter of the hose. It will not rust or wear out. It can be used as many times as desired. You need no make your hose as good as new and when once used you make your hose as good as new and when once used you doz., 80c; 1-inch hose, each, 12c; doz., $\$ 1.15$.

Hose Menders, Iron. - $3 / 4$-inch. Each $5 c$; doz., $45 c$; gross, $\$ 4.00$.

\section{NOZZLES}

Chicago NozzIe:-Each, $\$ 2.50$.

\section{Hose NozzIe, Boston Rose Spray.-Brass,}
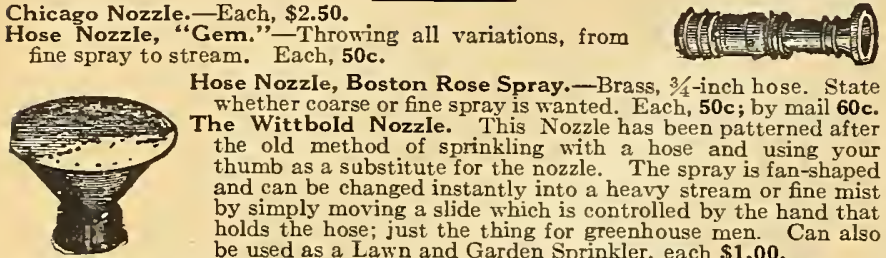

Whether coarse or fine spray is wanted. E 50c; by mail 60c. the old method of sprinkling Nozzle has been patterned after thumb as a substitute for the nozzle. The spray is fan-shaped and can be changed instantly into a heavy stream or fine mist by simply moving a slide which is controlled by the hand that holds the hose; just the thing for greenhouse men. Can also VermoreI Nozzle.-For spraying Insecti cides and Whitewash, 75c.

Bordeaux.-For Insecticides and White ashing, each, 75c.

Standard Nozzle. - (Brass.) Throws By mail, \$1.10.

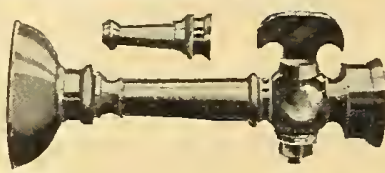

\section{INSECTICIDES}

ANT EXTERMINATOR. - We do not send this outside of States of Illinois or New York. A non-poisonous powder which scattered about their nests, kills or drives away ants from lawns, etc. Per box 25c; by mail 35c; smaller size, 15c.
APHINE.-For all kinds of plant lice. 1/2 pt., 40c; 1 pt., 65c; 1 qt., $\$ 1.00$; 1 gal., \$2.50.

12 sheets, $60 \mathrm{c} ; 1$ case 12 pkgs., $\$ 6.50$.

best known insecticide for all LeafEating Insects, adhering to the foliage for weeks, thus eliminating many repeated sprayings. There is absolutely no danger of burning or scorching th leaves. Lb., 25c; 5 lbs., \$1.00; 10 lbs., \$1.80; 25 lbs., \$3.75; 100 lbs., \$14.00. ment Stations throughout the United States, for soft bodied sucking insects. ment Stations throughout the United States, for soft bodied sucking insects.
For spraying only; directions must be followed carefully: $1 \mathrm{oz}, 25 \mathrm{c} ; 1 / 2 \mathrm{lb}$. can, For spraying only; directions must be followed carefully: 1 oz., 25c; $1 / 2 \mathrm{lb}$. can,
$\mathbf{7 5 c}$, makes 40 to 100 gallons; $2 \mathrm{lb}$. can, $\$ 2.50$, makes 200 to $500 \mathrm{gallons;} 10 \mathrm{lb}$. can, $\$ 10.50$, makes 840 to 2,100 gallons.

BORDEAUX MIXTURE.- (Dry.) The best fungicide for checking and preventing black rot, mildew, blight, leaf curl, scab or other similar diseases on
fruits and plants. 1 pound will make 5 gallons liquid. Lb., 25c; 5 lbs., $\$ 1.00$; kegs, 25 lbs., $\$ 4.50$

1 gal. will make 50 gals. liquid. 1 Ready $40 \mathrm{c}$; 1 gal., $\$ 1.00 ; 5$ gal. can $\$ 4.00$. FIR TREE OIL.-Fine spray for greenhouse and house plants affected with mealy bug, scale, red spider, black and green aphis, thrip, lice, worms and slugs. We do not send this outside of State of Illinois or Ne
bottle, 25c; $1 / 2$ pint, $40 \mathrm{c}$; pint, $75 \mathrm{c}$; quart, $\$ 1.25$; gallon, $\$ 4.00$.

bottle, 25c; $1 / 2$ pint, $40 \mathrm{c}$; pint, $75 \mathrm{c}$; quart, $\$ 1.25$; gallon, $\$ 4.00$.
FIR TREE OIL SOAP.-For thrip, red spider, black and green fly, mealy bug, WOrms, slugs. Per $1 / 2-\mathrm{lb}$. tin, 25c; by mail, 35c; 2 -lb. tin, 75c. FUNGINE.-New remedy for mildew, rust or

Flowers of Sulphur.-Lb., 10c; $10 \mathrm{lbs}$., 75c; 50 lbs., \$2.50; 100 lbs., $\$ 4.50$.

Grape Dust.- Excellent for the prevention and destruction of mildew on plants. Per lb., 10c; 5 lbs., $35 \mathrm{c} ; 10$ lbs., 50c.

Hellebore, Powdered White.-Less poisonous than Paris Green and safer to use when fruit and vegetables are nearly ripe. Per lb., $40 \mathrm{c} ; 5$ lbs., $\$ 1.75 ; 10$ lbs., $\$ 3.25$.

HORICUM.-Sulphur, Lime, Salt, etc., in such proportions as make an effective preparation for San Jose scale. Per gal., $\$ 1.00 ; 5$ gallons, $\$ 4.50$.

of the best insecticides for all soft-bodied suckplant lice, flea, plant lice, fea, aphist can, 40c; 1-gal. can, \$1.00; 5-gallon can, $\$ 4.50$.

LEMON OIL. - Destroys mealy bug, scale, thrip, red spider, etc. 1/2 pt., 25c; pt., 40c; qt., 75c; $1 / 2$ gal., $\$ 1.25$; gal., $\$ 2.00 ; 5$ gals., $\$ 9.00$.

IME-SULPHUR. - The best rimedy fan Jose scale One gallon makes ten. Also one of the best summer sprays, as it is an excellent fungicide. gal., $\$ 1.00 ; 5$ gal. can, $\$ 4.00$.

NICO-FUME." -A Tobacco Paper for Fumigating.-Paper saturated with high strength "Nicotine is undoubtedly the best and easiest possible method of fumigation. "Nico-Fume" is not only made of the strongest extract Tobacco and evenly distributed on the paper, but is put up in friction top tins so that as it is well known that Nicotine so applied, if exposed, will soon lose its strength. Full directions with every package. Price 24 sheets, 85c; 144 , sheets, $\$ 4.00$; 288 sheets, $\$ \mathbf{7 . 5 0}$. Special rates to large consumers.

NICO-FUME LIQUID.- One of the best compounds on the market, contains 40 per cent Nicotine and is sold at the following reasonable prices: ${ }_{14} \mathrm{lb}_{\mathrm{H}}, \mathbf{5 0 \mathrm { c }}$; $1 \mathrm{lb} ., \$ 1.50 ; 4 \mathrm{lbs}, \$ 5.50 ; 8 \mathrm{lbs}$., $\$ 10.50$

NICOTICIDE.-Fumigating compound for killing all kinds of insects on plants in greenhouses and frames.

1 gallon..

No. 3,1 pint, sufficient for 32,000 cubic feet of space

No. 2, 1/2 pint, sufficient for 16,000 cubic feet of space

$\$ 15.00$

8.25

2.50

1.25

Fumigators for above, each

NIKOTEEN.-Use same as Nicoticide. Pint, $\$ 1.50 ; 3$ pints

.75

X. L. AlI-Liquid Insecticide. - For spraying. English preparation, 13.00 nicotine, harmless to very delicate plants. Kills mealy bug, red spider and all insect pests. Price, f. o. b. Chicago, $1 / 2$ gal., $\$ 2.25 ; 1$ gal., $\$ 4.00 ; \mathrm{f}$. 0 . b., New

EN.-A poisonous insecticide in powder form, for insects which chew. When applied as a powder, use one part Paris Green to 100 parts plaster or flour. As a liquid, one pound of Paricklime. 1/2 lb. 22c; per lb., 40c; 5 lbs., used on fruit trees, add

\section{INSECTICIDES-Continued}

PYROX.-Kills all leaf-eating insects, destroys fungus growth, blight and rot. Mixes easily in cold water, sprays without clogging and sticks to foliage. Price, lb., $25 \mathrm{c}$

SCALECIDE.-Oil preparation for San Jose scale. Gal., \$1.25; 5 gals., \$4.00.

SLUG SHOT, Hammond's.-Especially desirable for destroying currant and gooseberry worms, but may also be used for any other garden insects. Price: on cars. Three barrels in bulk, per $100 \mathrm{lbs}$, at $\$ 4.00$.

SIug Shot Duster.-One gallon size, 35c.

Solution of Copper.-For use on trees, vines or vegetables affeeted with rot, blight or scab. Per pint, $40 \mathrm{c}$; quart, $65 \mathrm{c} ; 1 \mathrm{gal}$., $\$ 2.00$.

Sulpho Tobacco Soap.-One of the best remedies for green fly on roses. Per $1 / 2$-lb. box, 20c; dozen, \$2.00; 3-oz. package, dozen, 85c. A splendid article for retailing, sells at $10 \mathrm{c}$ per package.

Thrip Juice.-Destroys mealy bag, scale, thrip, codling moth, canker worm, beetles, caterpillars, etc. Per pint, 65c.

TOBACCO STEMS.-These prices are subject to change without notice on account of the uncertain upply of this article.

$100 \mathrm{lbs}$ $1000 \mathrm{lbs}$

Tobacco Dust, Regular Grade Onje 9.50 remedies for green and black aphis, fleas, beetles,
etc., 5 lbs. 25 c; 10 lbs., 40 c; 100 lbs., $\$ 3.00$.

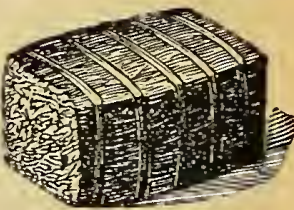

TOBACCO DUST, Fumigating and Dusting Kind.-Can be lighted with a match or hot iron and will smoulder until entirely consumed, throwing off a lbs., $\$ 3.50$.

TOBAKINE.-High Strength Nicotine preparation. 1 pt., $\$ 2.50$; $1 / 2$ gal., $\$ 9.00$; 1 gal., \$17.50.

FISH OIL SOAP.--Commonly known as Whale-Oil-Makes an excellent wash for trees and plants where insects and eggs affect the bark. Lb., 18c; 2 lbs.,

TREE TANGLEFOOT.-Perfect safeguard for trees. Lb., 30c; 3 lbs., 85c; 10 lbs., \$2.65.

ERMINE.-For eel, cut worms and wire worms working in the soil. It can be applied to all vegetation. Gal., $\$ 3.00$; quart, $\$ 1.00$.

\section{KNIVES}

Each

Asparagus.-American

Budding.-Imported, black hand

English Style.-Ivory handle.

Propagating.-English style ivory handle

Vaughan's Florist. - 3 for $\$ 2.10 ; 6$ for $\$ 4.00$

English Style.-Ivory handle, two bladed (budding and propagating)

Beech handle budding, with stationary blade.

Pruning.-English Stag handle.

Nurseryman's Heavy Pruner.

Two-bladed, stag handle with pruning and budding blade

$\$ 0.40$

1.00

1.25
1.25

$\mathbf{1 . 5 5}$

Putty Knife.-No. 120; a very good tool, 3 for 65

\section{LABELS, POT AND TREE}

We carry the best quality of Wooden Labels made in this country. They are smooth, strong and neat.

\section{POT LABELS}

In lots of 5,000 we allow discount of 5 per cent.

Wooden, 4-inch, plain....10,000, $\$ 5.00$ Plain. Painted.

Wooden, 4-inch, painted.. 10,000, $\mathbf{6 . 5 0}$

Wooden, 5-inch

Wooden, 6-inch

Wooden, 8-inch

Wooden, 10-inch

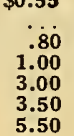

$\$ 0.85$

1.00
1.50

1.50
4.00

4.00
4.50

4.50
6.50

\section{TREE LABELS}

Wooden, 31/2-inch, iron wired.

Wooden, 312 -inch, copper wired.

COPPER LABELS.-Wired, indestructible. P
$\$ 1.50$. (See under "p" for Indelible Pencil.)

LEAF MOLD.-For Ferns, etc., elean stock, 6 bbls., \$9.60; per bbl.

\section{HOT BED MATS}

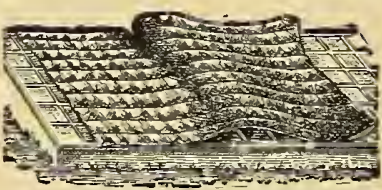

Burlap Mats, lined; waste wool and cotton, quilted. Size $\mathbf{A}, 40 \times 76$ ins. $\$ 11.00$

Size B, 76x76 in., ea. $\$ 1.60 ;$ doz. 16.00

Duck Mats. Same as above, with water proofed duck on one side to

shed rain. 6 in., ea. $\$ 1.50$; per doz. $\$ 16.00$ Size D, $76 \times 76$ in., ea. $\$ 2.15$; per doz. 21.50 Rattan Mats, Singapore Fibre. Mouse and rat proof, being made of flexible the market. $6 \mathrm{ft} 2$ in. long by $6 \mathrm{ft}$. wide; each $\$ \mathbf{2 . 4 0 ; 6}$ for $\$ 13.50$.

Mole Traps,-Out o' Sight. Each

\section{PLANT BED CLOTH}

A substantial substitute for glass and being light, shipped.

Medium, 20 yds. and $u p$,

per yd., 12c; 60 yds. and

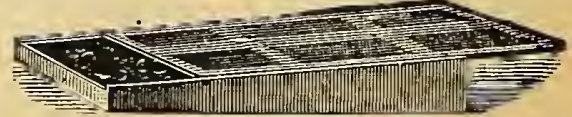

lp, per yd., 11c.

Heavy, 20 yds. and up, per yd., 18c; $60 \mathrm{yds}$. and up, per yd., 17c. We do nots sell less than 20 yards of a kind; it comes in 40 and 60 yard lengths. Samples on application. Width, $1 \mathrm{yd}$. 
VAUGHAN'S SEED STORE, CHICAGO AND NEW YORK

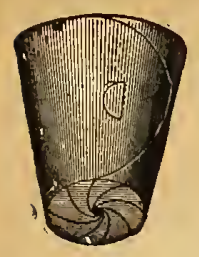

We are western agents for these pots. The cheapest Flower Pots on the market. They are made from Neponset Waterproof Fabric, and for lightness, cleanliness and cheapness have no equal. They are absolutely unbreakable, much lighter in weight then clay and are therefore splendid for shipping plants.

\begin{tabular}{|c|c|c|c|c|c|}
\hline $\begin{array}{c}\text { Size, } \\
\text { inch } \\
21 / 4 \\
21 / 2 \\
3 \\
31 / 2 \\
4 \\
5\end{array}$ & $\begin{array}{r}\text { Per } \\
100 \\
\$ 0.30 \\
.35 \\
.50 \\
.60 \\
.85 \\
1.20 \\
1.65\end{array}$ & $\begin{array}{c}\text { Per } 1000 \text {, } \\
\text { f. o. b. } \\
\text { New York } \\
\$ 2.20 \\
2.40 \\
3.70 \\
5.15 \\
6.40 \\
10.25 \\
14.35\end{array}$ & $\begin{array}{c}\text { Per 1000, } \\
\text { f. o. b. } \\
\text { Chicago } \\
\$ 2.42 \\
2.78 \\
3.82 \\
5.24 \\
6.60 \\
10.96 \\
14.68\end{array}$ & $\begin{array}{c}\text { Origina } \\
\text { crates } \\
\text { hold } \\
1000 \\
1000 \\
1000 \\
1000 \\
500 \\
500 \\
500\end{array}$ & $\begin{array}{c}\text { Gross wt. } \\
\text { of } 1000 \\
\text { pots about } \\
12 \text { lbs. } \\
17 \mathrm{lbs} . \\
23 \mathrm{lbs} . \\
35 \mathrm{lbs} . \\
46 \mathrm{lbs} . \\
80 \mathrm{lbs} . \\
110 \mathrm{lbs} .\end{array}$ \\
\hline
\end{tabular}

\section{EARTHENWARE HANGING BASKETS}

\section{TERRA COTTA}

7 inch

Ornamented with saucer attached.

8 inch.

10 inch

12 inch.

\section{FLOWER POTS, Standard White Clay}

Chicago. On orders for less than $\$ 10.00$ we charge for cart
assume risk of breakage on pots and like material.

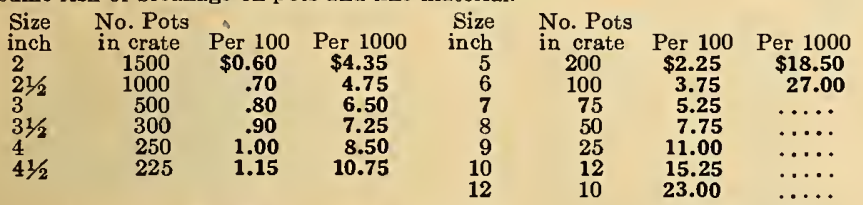

\section{FLOWER POTS, Standard Red}

F. O. B. Chicago.

We ship in original crates which we prefer not to break. When ordering from Chicago be sure to state if Red or White Pots are wanted, as otherwise we send Red.

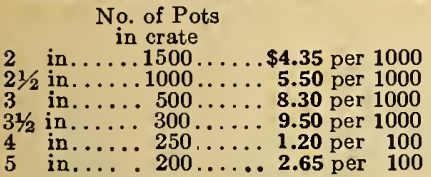

\section{FLOWER POTS, Standard Red} No. of Pots

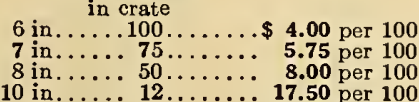
10 in $\ldots \ldots$
12 in $\ldots \ldots$
$10 \ldots \ldots \ldots$

We charge for cartage and packing on orders for less than $\$ 10.00$. Please number in package; we prefer not to repack.

\begin{tabular}{|c|c|c|c|c|c|c|c|}
\hline $\begin{array}{c}\text { Size } \\
\text { inch } \\
2 \\
2 \times 21 / 2 \\
21 / 2 \\
3 \\
31 / 2 \\
4 \\
41 / 2\end{array}$ & $\begin{array}{c}\text { No. Pots } \\
\text { in Pkg. } \\
1500 \\
1000 \\
1000 \\
500 \\
300 \\
250 \\
225\end{array}$ & $\begin{array}{c}\text { Per } 100 \\
\$ 0.40 \\
.70 \\
.70 \\
.90 \\
1.05 \\
1.25 \\
1.75\end{array}$ & $\begin{array}{c}\text { Per } 1000 \\
\$ 4.50 \\
6.50 \\
6.50 \\
8.50 \\
10.00 \\
12.00 \\
16.00\end{array}$ & $\begin{array}{r}\text { Size } \\
\text { inch } \\
5 \\
6 \\
7 \\
8 \\
9 \\
10 \\
12\end{array}$ & $\begin{array}{c}\text { No. Pots } \\
\text { in Pkg. } \\
200 \\
100 \\
75 \\
50 \\
25 \\
12 \\
10\end{array}$ & $\begin{array}{r}\text { Per } 100 \\
\$ 2.75 \\
3.50 \\
5.75 \\
8.00 \\
11.00 \\
17.75 \\
32.50\end{array}$ & $\begin{array}{c}\text { Per } 100 \\
\$ 26.00 \\
\ldots \ldots \\
\ldots \ldots\end{array}$ \\
\hline
\end{tabular}

RAFFIA. Prices Subject to market fluctuations.

Natural, Regular Grade, f. o. b., Chicago; lb., 25c: 10 lbs., \$2.00; 100 lbs., $\$ 15.00$; full bale lots, per 100 lbs., $\$ 13.00$; shipped from New York, 50c per 100 lbs. less.

Natural, Florists' Grade, f. o. b. Chicago; lb., 30c; $10 \mathrm{lbs} ., \$ 2.25 ; 100 \mathrm{lbs} .$, 100 lbs. less.

RAKES, Garden

STEEL GARDEN RAKES. 12 teeth, 50c; 14 teeth, 60c; 16 teeth, 75c.

FINE TOOTH STEEL GRAVEL RAKES. 16 teeth, 70c; 18 teeth, 75c

STEEL "BOW" GARDEN RAKE. The best rake; does not break in middle; 12 teeth, 60c; 14 teeth, 75c; 16 teeth, 90c.

WOODEN HAY RAKES. Best quality, 12 teeth, 60c.

\section{HOT BED SASH, UNGLAZED}

The prices we quote are for sash made of Cypress.

HOTBED SASH.

Unglazed, $3 \times 6 \mathrm{ft}$., for 3 rows, 10-inch single glass, each, $\$ 1.50 ; 3$ for $\$ 4.40 ; \mathrm{doz}_{1}, \$ 17.50$. Glazed, each $\$ 3.50$; doz., $\$ 41.00$.

For 38 in. $x 6 \mathrm{ft}$. , for 4 rows, 8 inch single glass, unglazed $\$ 18.50$. Glazed, each $\$ 3.60$; 3 for $\$ 10.70$; doz., $\$ 41.80$.

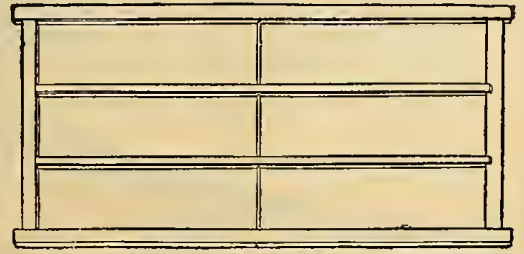

Double Glass Sash, $3 \times 6$ ft., for 3 rows 10-in. glass, unglazed, each $\$ 2.35$; 3 for $\$ 6.95$; doz. $\$ 27.75$. Glazed, each $\$ 5.25$; 3 for $\$ 15.65$; doz., $\$ 61.50$. For 38 in. $x 6 \mathrm{ft}$., for 4 rows 8-in. glass, unglazed, each $\$ 2.45 ; 3$ for $\$ 7.35$; doz., $\$ 28.95$. Glazed, each $\$ 5.35 ; 3$ for $\$ 15.95 ;$ doz., $\$ 62.50$.

Our sash are made of clear air-dried Cypress. Unglazed sash are not painted. Glazed sash are painted one coat.
PRUNING SAWS

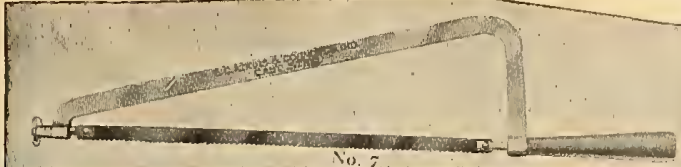

Vaughan's Perfection Pruning. Made of the best steel with adjustable blade, so any branch can be easily removed close to trunk of the tree. Can be used a blades, $25 \mathrm{c}$.

SCYTHE BLADES-English, 30-inch, $\$ 1.40 ; 36$-inch, $\$ 1.50 ; 40$-inch, $\$ 1.60$.

\section{SHEARS, German Pruning}

Solid Steel. 41/4 inch, 90c; 51/2 inch, $\$ 1.00 ; 61 / 2$ inch, $\$ 1.10 ; 71 / 2$ inch, $\$ 1.25 ; 81 / 2$ inch, $\$ 1.35 ; 91 / 2$ inch, $\$ 1.50$. Extra springs, each $15 \mathrm{c}$.

California Pruning Shears. Our best grade, extra strong, with double brass springs. $81 / 2$-inch, each

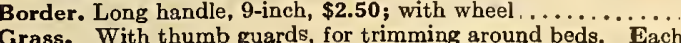

Hedge. Best imported. 8-inch, \$1.35; notched, \$1.50; 9-inch

9 -inch, notched, $\$ 1.75 ; 10$-inch $\$ 1.90$; notched.

Buckeye Pruner. Light, 20 -inch handle, $\$ 1.65 ; 26$-inch handle

Clyde Draw-Cut Pruner. Extra strong, long handle.

Levin's Improved. Most powerful shears made. Each

Improved Wire. For cutting annealed wire. Each, 85c; 3 for

SICKLES-English. Each

\section{SOD CRUSHERS}

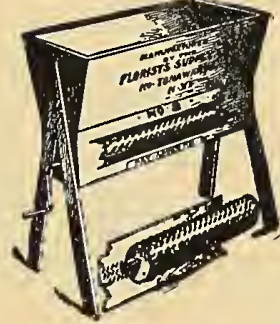

No. 1 Machine. Total height, 46 inches; size of roll, $6 \times 21$ inches, suitable for 5,000 feet or less of glass. Each, $\$ \mathbf{1 5 . 0 0}$.

No. 2 Machine. Total height, 46 inches; size of roll, $6 \times 42$; suitable for large establishment. Each, $\$ 20.00$.

\section{SPRAYERS}

Eight to ten strokes of the plunger in the air chamber will compress enough air to discharge the contents. The "Auto Spray" has been improved by the addition of the "Auto Pop," an automatic valve, which is closed by the air pressure used to operate the "Auto Spray." In operation a lever is
moved by simply closing the hand, thus opening the valve and allowing an instantaneous discharge of spray. By releasing the lever it closes itself automatically; hence spray is in perfect control. Price: Galvanized iron reservoir, with "Auto Pop", \$8.25; brass extension rod, in 2 -foot lengths, each 45c; two-bow spray attachment, \$1.35.

\section{BINK SPRAY}

A medium priced sprayer constructed of best material and will do good work. It is ecuipped with feet discharge hose, shut-off cock, and our Star spray nozzle and shoulder stap. Works with compressed air. Price.

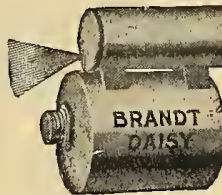
$\$ 6.50$

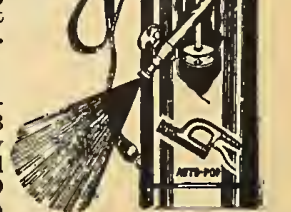

.50

\section{Ferguson's Combination Sprayer and Syringe}

Three Roses with each. Made of brass. Splendid for syringing under the foliage of plants where force is needed. $1 / 4$-inch connection.

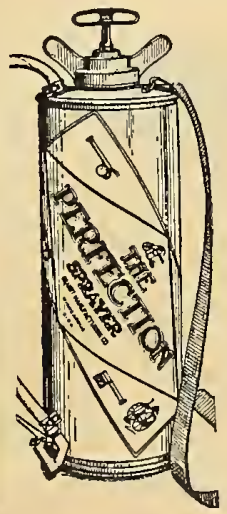

\section{THE LOWELL}

For applying insecticides in the form of a mist or vapor. The of glass, which enables the oper-

THE DAISY

A splendid little hand sprayer which has the advantage over similar makes that it will spray when held either up or down. The plunger is fitted with a double washer which gives a spray with the back-
ward stroke as well as with the forward. Each......65c

ator to see the ingredients mixing. The glass sprayer will not corrode or rust, and if accidentally broken, can be replaced at once with a Mason Fruit Jar.

Price: each 75c; 3 for. . . . . . . . . . . .

$\ldots 2.00$

\section{SIMPLEX SPRAYER}

$31 / 2$ gallon, a system of air tubes inside the tank produces with every stroke of the pump a rotary motion of air and liquid around bottom of tank agitating any of the ingredients that have a tendency to settle. Galvanized, $\$ 3.75$;
Brass, $\$ 6.00$.

\section{PERFECTION}

The tank is made of heavier metal than has been previously used for similar sprayers, while the valve and pump hose is attached at such an angle that it will not kink. Unexcelled for Whitewash, Water Paints, Insecticides, etc Made .n galvanized steel or brass. Galvanized Steel, $\$ 5.50$; All Brass, $\$ 8.00$. 


\section{SPRAYERS-Continued.}

\section{PNEUMATIC SPRAYER}

A compressed air hand sprayer. Cuts labor of ordinary sprayer in half. Will throw a fine mist. Splendid for applying insecticides, etc.

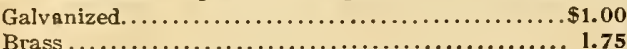

\section{SPRAY PUMPS}

DIAMIOND Spray Pump.......................\$4,00 PUMP, The Kinney. Each.................... 2,00 SUCCESS Spray Pump. The hesthucket pump..... 4.00

\section{SYRINGES}

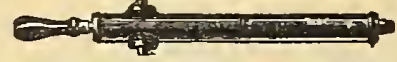

No. 0 . Length. $12^{1} / 2$ inches; diameter, $15-16$ inch..... 2.00 No. B. Larger; $13 \frac{112}{2}$ in. long; $13-16$ in. in diameter... 2.50 No. C. $14^{1 / 2}$ in. long; $15-16$ in. in diameter.......... 3.50

No. D. $15^{1}, \mathrm{in}$. long; $1 \frac{1}{2}$ in. in diameter........... 3,75

No. 5. Best for general greenhouse work.......... 6.00

No. 11. 18 in long: 1 stream, 2 sprays.

No. 12. 14 in. long: 1 in. in diameter.

2.75

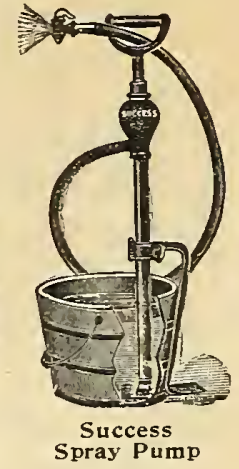

\section{CANESTAKES}

PLANT STAKES

Standard Grade. 6 to 8 feet long and weigh ahout 170 to 180 pounds per 1000 . Price (at Chicago). per 100, 70c; 500 for $\$ 2.85$; per 1000, \$5.25;. (At New York), per $100, \$ 1.15 ; 500$ for $\$ 3.40 ; 1000, \$ 6.35$. Special price on larger

lovy Grade. For special work. Dahlias, etc., 9 to 12 feet,weigh ahout 250 pounds per 1000 . Price (in Chicago). per $100, \$ 1.75 ; 500$ for $\$ 7.00 ; 1000$ pounds per

Japanese Bamboo. Light, strong and more durahle than ordinary canes. Fine for staking lilies. Price (at Chicago) per $100.65 \mathrm{c}$. per $1000 \$ \mathbf{5 . 2 5}$; per 5000 $\$ 23.00$. (At New York), per $100,60 \mathrm{c} ; 1000, \$ 4.75 ; 5000, \$ 22.00$.

Green Painted Japanese Bamboo. Neat, strong and durahle; hest for pot plants. Painted green they can he used for the most critical trade.

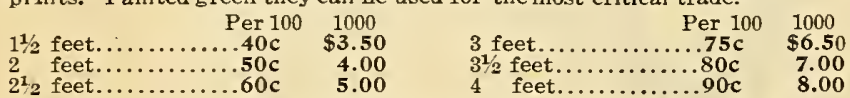
Pipe Stems. 4 to 6 feet long, weight, per 1000,54 pounds. F. O. B. Chicago 100 for $60 \mathrm{c} ; 500 . \$ 2.00 ; 1000, \$ 3.50$.

Wooden, Green. Handsome and convenient for Gladiolus, etc.

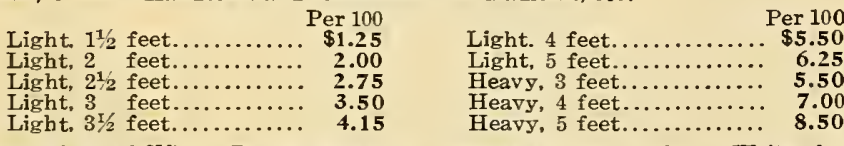

Galvanized Steel Wire. Prices suhject to change without notice. Write for latest quotations on quantities. Far superior to wooden stakes and practically indestructible.

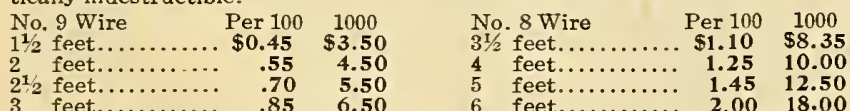

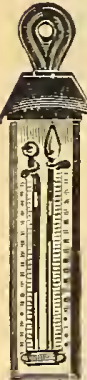

\section{THERMOMETERS}

Tin Case -8 inch. each, $15 \mathrm{c} ; 12$ for $\$ 1.50 ; 10$ inch, each, $\$ 1.85$

Cabinet. - Wood case and metal face, 3 for $\$ 1.15$; each. .40 Imported German. -All glass for propagating hed, each, $\quad \mathbf{. 4 5}$ Self Registering. -With magnet, 8 inch, each........ 3.00 Minimum.-For registering cold during ahsence and showing present temperature. Each.............. 1.75 HOT BED (Mushroom),-Brass point, wood frame, each....................................... 2.00

\section{TREE PRUNERS}

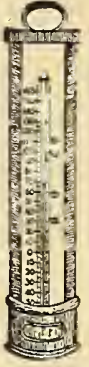

WATERS.-Length of pole, 4 feet, 50c; 6 feet, $75 \mathrm{c} ; 8$ feet $90 \mathrm{c} ; 10$ feet, $\$ 1.00$ 12 feet, \$1.10. Extra hlades, each, 20c.

\section{TROWELS}

Vaughan's Steel - Best Trowel made, one solid piece of steel, and will outwear several ordinary ones. Each, 50c; 3 for \$1.40. Postpaid each, 60c.

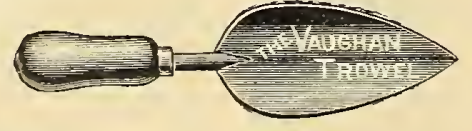

Ordinary Garden Trowel. 6 inch, 10c; dozen, $\$ 1.00$

English Steel.-An excellent trowel, neat and very durable, 6 inch, each $25 \mathrm{c}$; for 60c; dozen, $\$ 2.00$

\section{TWINE}

"THE QUEEN"' White Cotton Twine.-For tying parcels, flowers, etc Put up in 5 -lh. sacks. Price....

Jute.-For hun ching; 2 or 3 ply, per lh. 20 ; 10 lhs, $\$ 1.90 ; 100$ lhs

SILKALINE.-For stringing Smilax, etc; fast green colors, will not fade or

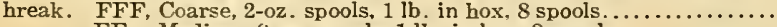
FF Medium, ' $-0 z$. spools, 1 lh in box, 8 spools.' FF, Medium. 2-oz. spools, 1 h. in box, 8 spools. ...... FLORISTS, THREA D. - Similar to Silkaline. Samples on application.

"King A rthu"

\section{WATERING POTS}

American--Heavy galvanized round can, two copper faced roses, long spout, 4 quart. $\$ 1.75 ; 6$ quart, $\$ 2.00 ; 8$ quart, $\$ 2.25 ; 10$ quart, $\$ 2.50 ; 12$ quart, $\$ 2.75$.

French Style. - Oval, otherwise same as ahove. 6 quarl, $\$ 2.25 ; 8$ quart, $\$ 2.50$. 10 quart, $\$ 2.75 ; 12$ quart, $\$ 3.00$.

\section{WEEDERS}

Piqua Lawn Weeder, \$1.00. Excelsior, Hand, each, 10c, Hazeltine, hand, each, 20c; dozen, \$2.00. Combination, each, 20c; dozen, $\$ 2.00$.

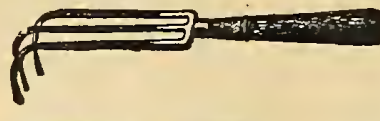

Eureka. - The hest hand weeder for loosening soil around plants. Thin forged steel fingers.

Short-handled $\ldots \ldots \ldots \ldots \ldots \ldots, \mathbf{2 5} \mathrm{c}$
Long-handled $. . \ldots \ldots \ldots \ldots, 35 \mathrm{c}$

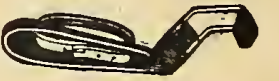

Lang's.- This we find to he hy actual trial a first class lahor saver. Price, each...... \$0.20

Magic Weeder and Hoe.

A handy tool, weeder part having four long tines. When reversed can he used as a hoe. Each, 30c.

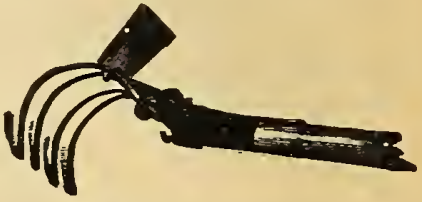

\section{WHEELBARROWS}

VAUGHAN'S GREENHOUSE. Made especially for greenhouse use between henches. Dimensions: Box 14 inches wide at wheel end; 16 inches wide at handle end; 12 in. deep. The hottom of the hox is matched and glued together, leaving no crack to interfere with shovel. Wheel is steel, 17 inches high, $2^{1} / 2$ inch thread; 15 inch axle. The harrow is 20 inches wide over all, made of the hest material, legs reinforced hy iron straps. Price $\mathbf{\$ 4 . 5 0}$.

THE GLOBE GARDEN.

Measurement of hox 30 inches long, 19 inches wide at wheel, 24 inches at handles. Price, with steel wheel............ \$4.00

\section{HAND CORN PLANTER}

"The Eagle." This is a rotary planter, having three different sized plates which can he easily changed. Each, \$1.25.

\section{CAHOON SEEDER}

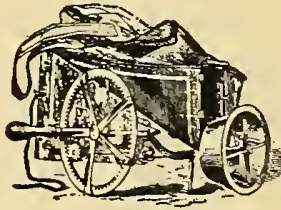

It will seed evenly four to six acres per hour. It will scatter the following distances: Wheat, Barley, Rye, 25 feet; Clover and Timothy, 18 to 20 feet. The bag and hopper hold ahout 22 quarts. Weight, 51/2 lhs. Price, \$3.00.

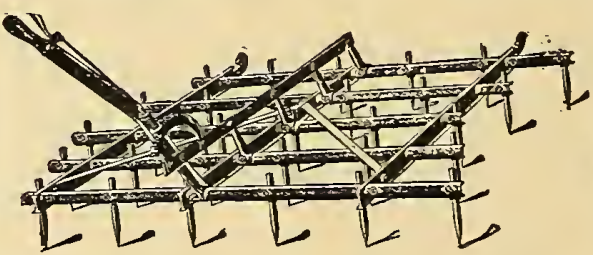

\section{SHOVEL PLOW}

\section{with Hinged Wings}

This is one of the most valuahle tools a market gardener can have. The wings are adjustahle and can he set to suit any width of row, Price, \$3.25
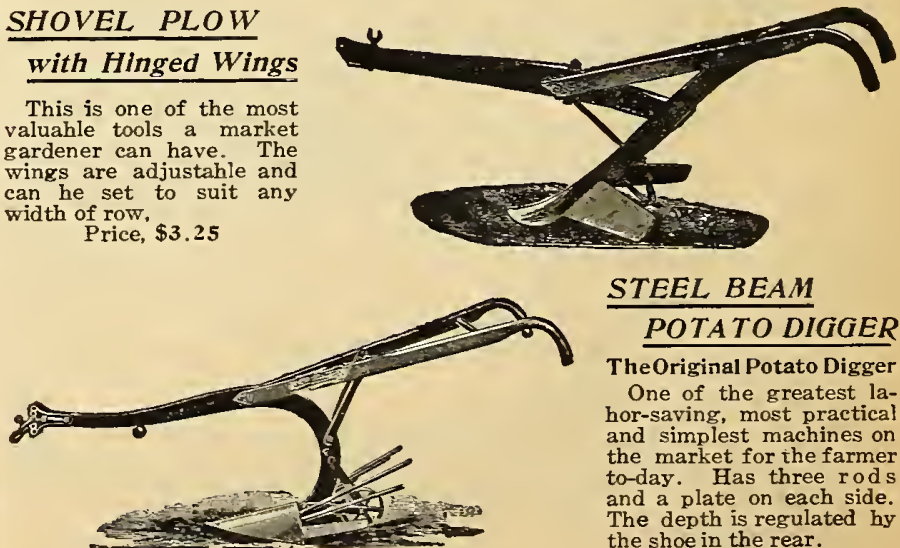

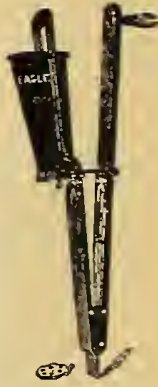 \\ PERFECT STEEL LEVER HARRO W All steel in two section 30 teeth in section; light strong, flexihle. Teeth are spaced so as to cover ground thoroughly. They can he pitched forward to pulverize, or slanted hack- ward for smoothing or clearing themselves.} (1) POTATO DIGGER TheOriginal Potato Digger One of the greatest lahor-saving, most practical and simplest machines on the market for the farmer to-day. Has three rod The depth is regulated hy the shoe in the rear. 


\section{The Yield and Quality of Vegetables Depend Upon Continuous and Rapid Growth}

It has been demonstrated that market-garden crops of the best quality are those which are grown under conditions which permit of a continuous and rapid development. Any delay in the growth of a lettuce or radish causes that sharp and pungent flavor of the former and the bitterness and toughened fibre of the latter, beets become stringy, etc. Plant food of the right amount and kind
trols the yield and quality of market-garden-products more any other condition, and it is neither wise nor economical to dep on the natural condition of the soil or the application of stable manure only for profitable crops.

\section{VAUGHAN'S 5-8-1 TRUCK AND FARM MANURE}

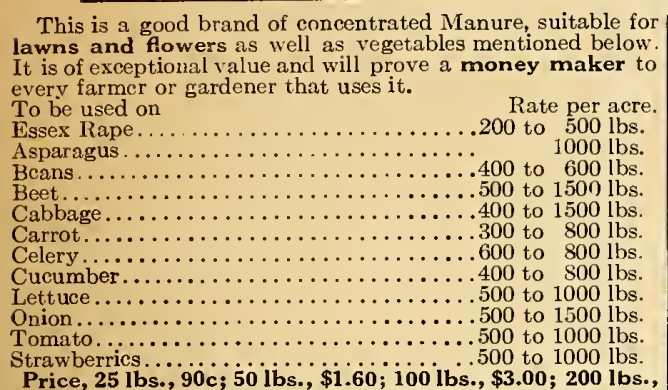

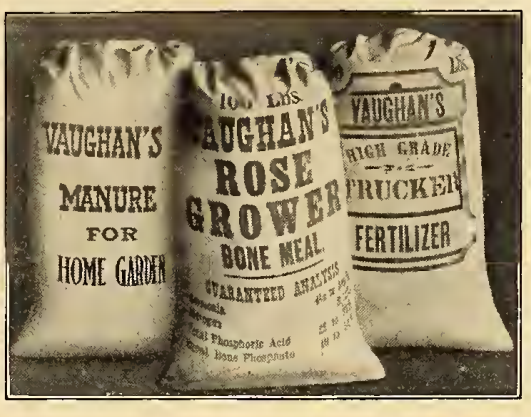

VAUGHAN'S “ROSE GROWER” BONE MEAL
REGULAR BONE MEAL. 5 lbs., 20c; 10 lbs., 35c; 25 lbs., $65 c ; 50$ lbs.,
$1.20 ; 100$ lbs., $\$ 2.15 ; 200$ lbs., $\$ 4.00 ; 500$ lbs., $\$ 9.25 ; 1000$ lbs., $\$ 18.00 ;$ ton $\$ 1.20$;

RAW BONE MEAL. 100 lbs., \$2.60; 500 lbs,. \$11.00; 1000 lbs., \$21.00; ton, $\$ 40.00$.

NITRATE OF SODA or Chili Saltpeter. Nitrate of Soda is not,

\section{ures, but we recommend it as the cheapest and best form in which to apply Nitro-} gen to plants. Gardeners who are using farm manure should continue to use 1 t,
but use Nitrate of Soda in addition to other fertilizers. If your object is to grow maximum crops you must in some way furnish the plants with Nitrogen. No maximum crops you must in some way furnish the plants with Nitrogen. No Nitrate before the plants can use it.
HOW TO USE NITRATE OF SODA

Remove the lumps before using and break them up which can be done by pounding. Use as a top-dressing at the rate of 100 lbs. per acre on the following vegetaber, Celery, Egg Plant, Lettuce, Spinach, Onions.

ber, Celery, Egg Plant, Lettuce, Spinach, Onions.
For Asparagus, a top-dressing of 250 lbs. per acre just as soon as the first shoots make their appearance.

For Strawberries, a top-dressing of about $100 \mathrm{lbs}$. per acre after the plants have

For the Home Garden apply as a solution one ounce to two sallons of water.

Price (subject to market changes), 5 lbs., 40c; 10 lbs., 65c; 25 lbs., \$1.45; Strawberries, 500 to 1,000. Price, 25 lbs., 70c; 50 lbs., $\$ 1.35 ; 100$ lbs., $\$ 2.50$ 200 lbs., $\$ 4.50 ; 500$ lbs., $\$ 10.50 ; 1000$ lbs., $\$ 19.50 ; 2000$ lbs., $\$ 36.00$.

BONE AND BLOOD. For Cabbage, Cauliflower, Corn and desirable for root crops except it is used in connection with potash. salts, or hardwood ashes, and if so used it is especially adapted to fruits, if applied early. For garden crops use 300 to 500 lbs. per acre. 500 lbs., $\$ 9.50 ; 1000$ lbs., $\$ 18.25 ; 2000$ lbs., $\$ 36.00$.

CLAY'S FERTILIZER. This valuable imported manure is grow either fruit, flowers or vegetables, and wish to bring them to the highest perfection. It should also be used in potting soil and as a top-dressing. Price, 7 lbs., 75c; 14 lbs., $\$ 1.25 ; 28$ lbs., $\$ 2.50$; 56 lbs., \$4.00; 112 lbs., $\$ 7.00$.

BONE BLOOD AND POTASH FERTILIZER MIXTURE 5-8-3 Per Cent Analyses. This is our best brand of concentrated soil use about 20 pounds to a cubic yard of soil, and for the dressing scatter it about as thick as lawn grass is sown, after loosening the surface of
$\mathbf{2 5}$ lbs., $\$ 1.35 ; \mathbf{5 0}$ lbs., $\mathbf{\$ 2 . 5 0 ;} \mathbf{1 0 0}$ lbs., $\$ \mathbf{4 . 5 0 ; 5 0 0 ~} \mathbf{l b s}, \mathbf{\$ 1 9 . 2 5}$

DRIED BLOOD For top-dressing, for mixing with the soil, and for applyous fertilizers. It is splendid for roses, carnations, 'mums, all kinds of pot plants. ous fertilizers. It is splendid for roses, carnations, 'mums, all kinds of pot plants.
Price, F. O. B. Chicago; 5 lbs., 40 c; 10 lbs., 70c; 25 lbs., $\$ 1.45 ; 50$ lbs., $\$ 2.25$; 100 lbs., $\$ 4.25 ; 200$ lbs., $\$ 8.25 ; 500$ lbs., $\$ 19.25$.

HARD WOOD ASHES This is a splendid fertilizer for the garden, connitrogen. Price, 25 lbs., 50c; 50 lbs., 85c; 100 lbs., $\$ 1.50 ; 500$ lbs., $\$ 5.00$; nitrogen. Price, 25 lbs., $50 c$.
1000 lbs., $\$ 9.25 ;$ ton, $\$ 18.00$.

HORN SHAVINGS. These are largely used by florists on such plants as Parks and Cemeteries to supply food after the natural fertility of the soil is ex hausted. Price, 5 lbs., 40c; 10 lbs., 70c; 25 lbs., \$1.25; 100 lbs., $\$ 4.50$.

LAND PLASTER OR GYPSUM. 100 lbs., \$1.25; 500 lbs., \$4.50. PURE ICHTHEMIC GUANO. An Ideal Plant Food, that exactly fulfils Vegetables in a well-balanced form.

DIRECTIONS FOR USE.-(1) In the dry state, 1 to 2 ounces to the square yard of ground. (2) In a liquid state, a tablespoonful to a gallon of water in the case of pot plants, about three times a week. (3) In a dry
state mix with soil, when potting, 1 part to 100 parts of soil. Imported in state mix with soil, when potting, 1 part to 100 parts of soil. Imported in
original bags of $112 \mathrm{lbs}$. each. Price, 28 lbs., $\$ 3.00 ; 56$ lbs., $\$ 4.50 ; 112$ lbs., $\$ 8.00$.

SCOTCH SOOT. (Genuine Imported.) Gardeners know the value of lating a healthy growth of dark green foliage, and its beneficial effect in freeing the soil from slugs, grubs and cut worms. Price, 28 lbs., \$1.65; 56 lbs., \$2.75; 112 lbs., $\$ 4.25$.
100 lbs,, $\$ 5.00$; original sack (220 lbs.), $\$ 9.50 ; 500$ lbs., $\$ 20.00$.
Write for prices on larger quantities.

\section{VAUGHAN'S SHEEP MANURE}

This is a pure, natural Manure, and its effect is immediate; it is excellent for mixing with the soil for greenhouse plants-one part
manure and six parts soil. Strewn over and dug into the vegetable manure and six parts soil. Strewn over and dug into the vegetable
garden or placed directly in drills or hills, it promotes a rapid, steady growth until maturity. It makes the richest, safest and quickest
Liquid Manure. For use in liquid form, one pound to five gallons of Liquid Manure. For use in liquid form, one pound to five gallons of 100 lbs., $\$ 1.95 ; 500$ lbs., $\$ 8.00 ; 1000$ lbs., $\$ 13.00$; ton, $\$ 24.00$;

\section{VAUGHAN'S CONCENTRATED PLANT FOOD}

A most useful Fertilizer for all kinds of plants raised in pots. It produces a rapid and vigorous growth and an abundance of flowers.

Package containing food for 20 plants for 3 months. $15 c ; 3$ for 40 ; if by mail, add 5c per package. Large Package, containing aufficient plant food for one year, 25c; 3 for 65c; if by mail, add 10 c per package. Ful directions in eacn pkg:

LEAF MOLD. For Ferns. Clean Stock. $\$$ Per bbl., $\$ 2.25 ; 6$ bbls., $\$ 12.00$.

SULPHATE OF AMMONIA. Used for its Nitrogen. A very desirable leaf development or rapid growth is desired. Use 1 pound to 50 square feet of ground or bench, or a tablespoonful to a bushel of soil, or 3 gallons of water. Price, 1 lb., 25c; 5 lbs., 65c; 10 lbs., \$1.25; 25 lbs., \$2.00; 100 lbs., $\$ 7.50$.

SHREDDED CATTLE MANURE. An efficient, high grade natural manufactured by special process from selected fresh cleanings from cattle pens There is no offensive odor, and when spread on lawn and garden it works down into the soil so there is no ref use to blow about or be raked off when the growing season
begins. If applied to the lawn in the fall it protects the grass roots all through the wegins. If applied to the lawn in the fall it protects the grass roots all through the
sinter. It is as easy and cleanly to handle as grain, being perfectly dry and can be
stored anywhere until wanted for use. Price, f. o. b., Chicago: 100 lbs., \$1.80; stored anywhere until wanted for use. Price, f. $\mathbf{o}$.
$\mathbf{5 0 0}$ lbs., $\$ 7.00 ;$
1000 lbs., $\$ \mathbf{1 2 . 5 0} ; 2000$ lbs., $\$ 21.00$.

REGARDING PRICES.-The above prices on Clay's Fertilizer, Nitrate of Soda, Horn Shavings, Scotch Soot, Guano are f.o. b. New York or Chicago; all the other prices are $f$. o. b. Chicago; if to be shipped from New York, add at the rate of $50 \mathrm{c}$ per $100 \mathrm{lbs}$, , or $\$ 7.00$ per ton on lots of $1000 \mathrm{lbs}$. 


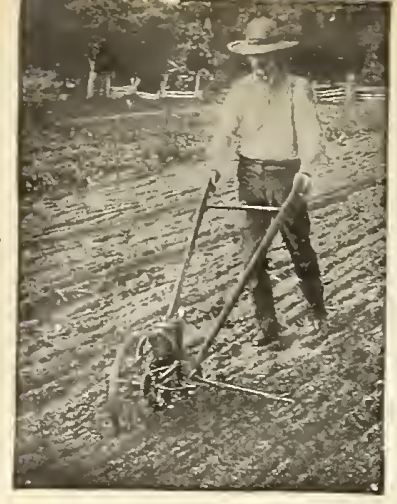

\section{Double and \\ Single \\ Wheel Hoes}

We are Special Chicago Agents for Iron Age Tools.

More than 30 years' experience selling garden tools has shown us that the "Iron Age" line is the best in every way. Built right, of the best materials obtainc.ble and designed to do all the sowing and cultivating necessary in a first-class garden. They are complete, adaptable tools-the kind you don't want to part with after you have once used them and know what they will do for you.

Transportation charges prepaid to any railroad station in the United States within 500 miles of Chicago or New Fork, on orders for "Iron Age" tools, or for seeds and tools amounting to $\$ 7.50$. (Seeds not prepaid unless so offered on other pages.)
No. 6 Combined Double and Single Wheel Hoe,

\section{Hill and Drill Seeder.}

The most practical and complete garden tool on the market-four machines in one-a hill seeder, a drill seeder, a double wheel hoe to work

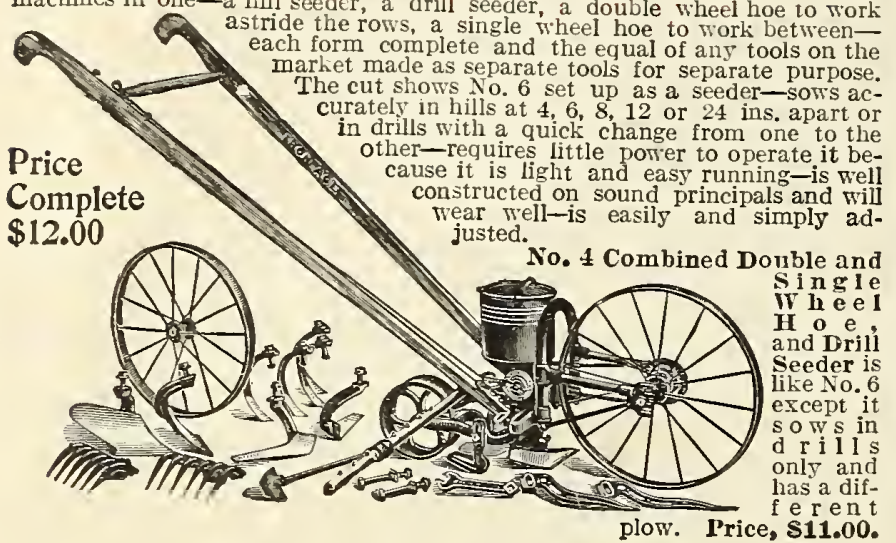

No. 15 Combined Single Wheel Hoe, Hill and Drill Seeder.

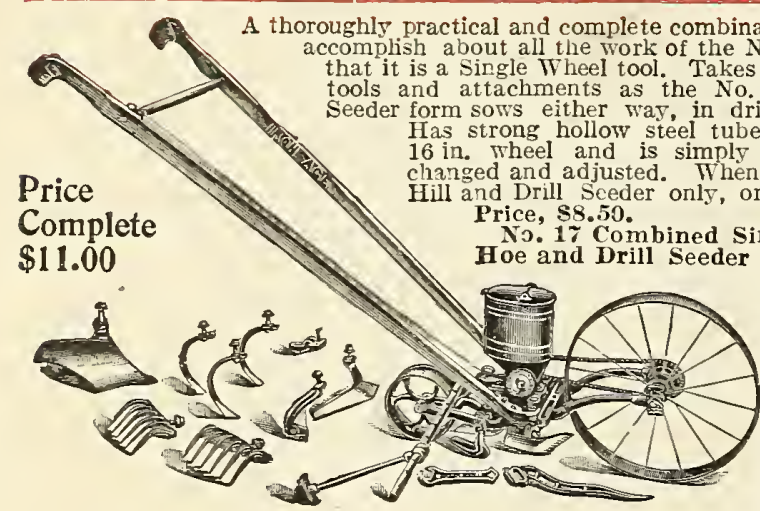

ws either way, in drills or hills. 16. Theel and is simply and easily Hill and Drill Seeder only, order No. 16. Complete
$\$ 11.00$ $\begin{aligned} & \text { Price, \$8.50. } \\ & \text { Hoe and Combined Single Wheel }\end{aligned}$

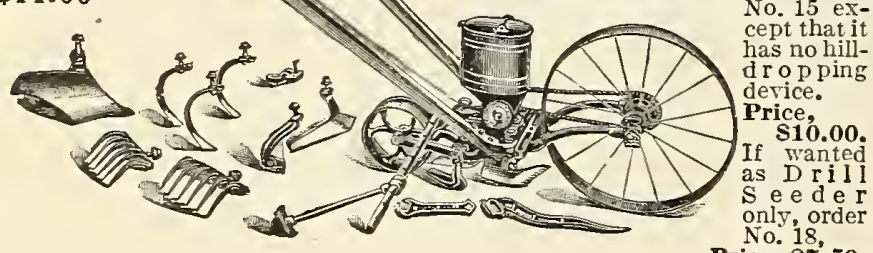

No. 1 Combined Double and Single Wheel Hoe.

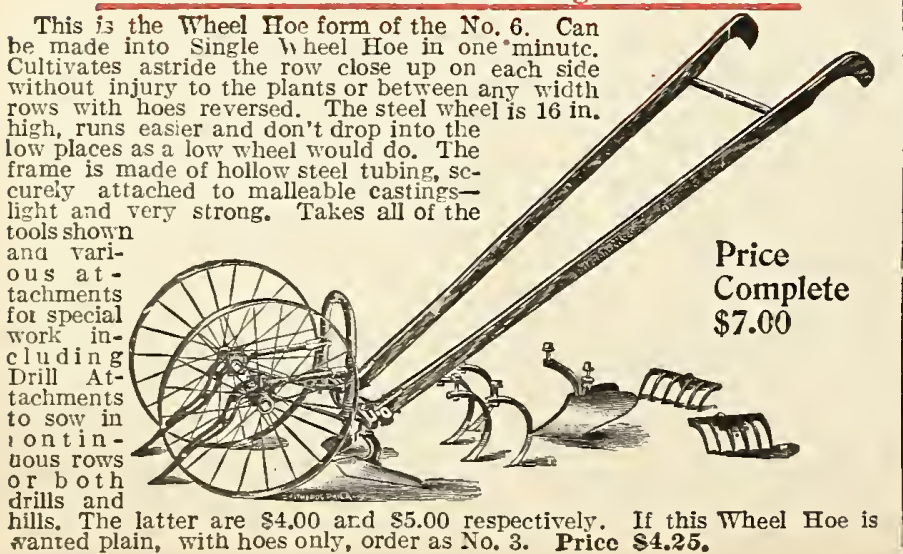

New

Model

Seed

Drill.

Popular

with seeds-

market

gardeners.

Exact reg-

ulation of

charge by

centric in-

cator which

adjusts the

seed open-

ing exactly

where you

series of holes

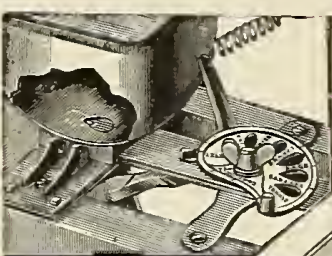

NEW PERFECT INDEX

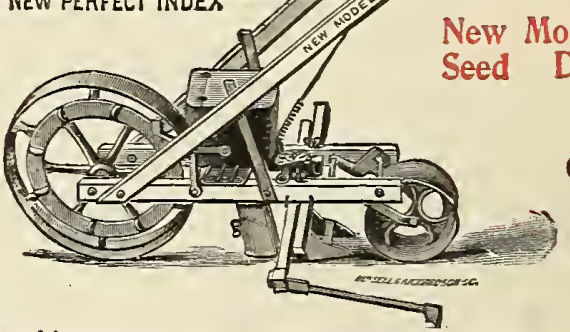

New Model

Seed Drill.

Price.

Complete $\$ 8.00$. ing of holes wh:ch have to be used whether they answer or not. A swing"Gem" Single Wheel Garden Hoe.

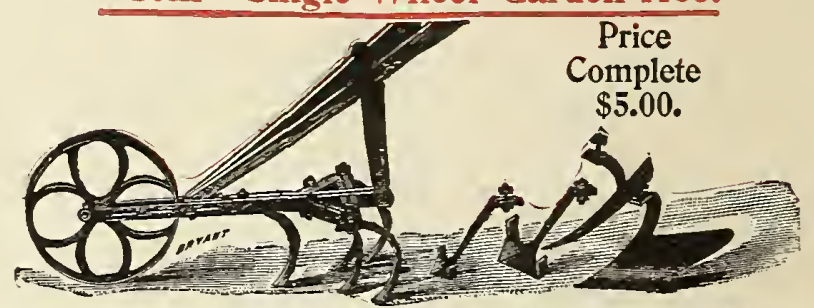

Built largely of steel and malleable iron. Theels and handles adjustable for height. The tools include five slender cultivator teeth, tsio sizes of cultivator teeth and a pair of plows which can be used separately or together.

\section{Horse Hoe Cultivator}
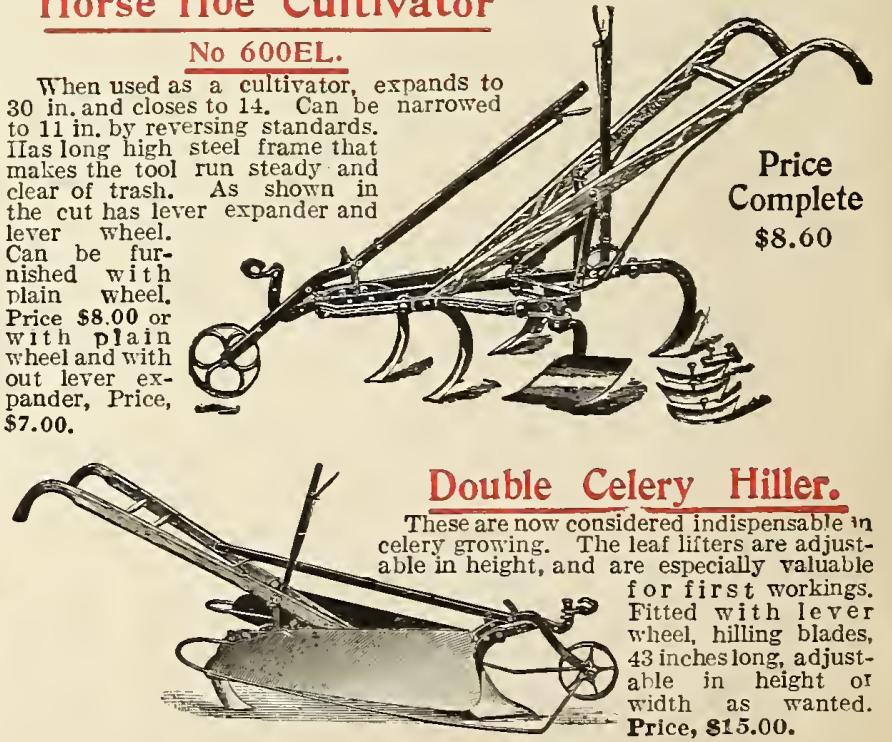

\section{Single Celery Hiller.}

Runs lighter than the double, and throws rather higher; it works any width rows. Where market gardeners plant close and first bleach every other row, it is "just the thing." Price, \$12.00. 